\title{
HISTORIA DO VOCABULARIO
}

Aquilino Iglesia Alvariño

DOI: 10.17075/fmfhv.2021.005 



\section{I. [O CAMIÑO HISTÓRICO DA LENGUA GALLEGA]}

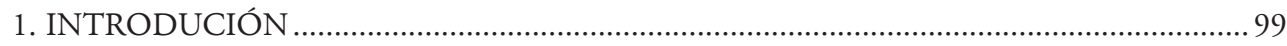

2. O ESTUDIO DO GALLEGO...................................................................................... 104

\section{OS VOCABULARIOS}

1. XENERALIDADES

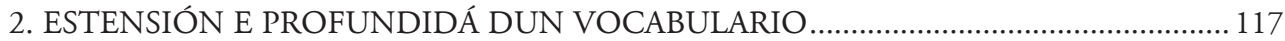

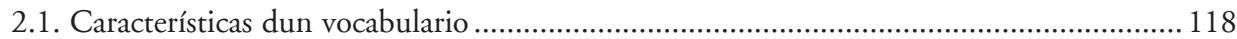

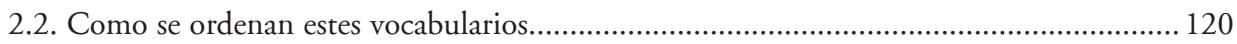

3. O FONDO ORIXINARIO DO VOCABULARIO GALLEGO …........................................ 123

\section{RENOVACIÓN DO VOCABULARIO}

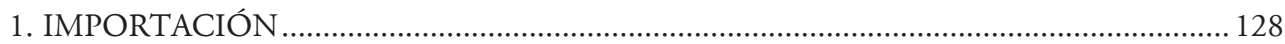

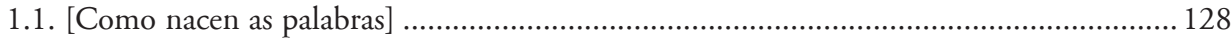

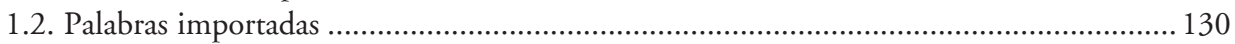

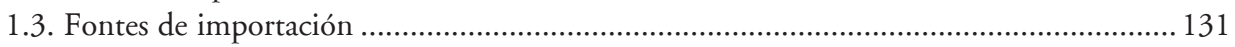

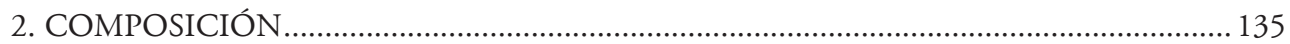

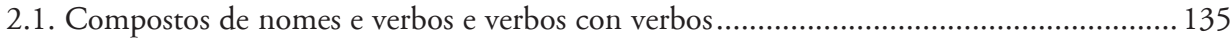

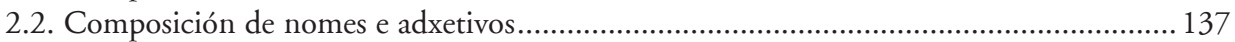

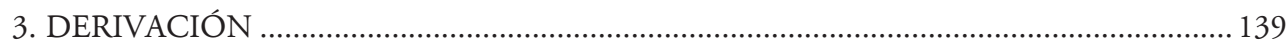

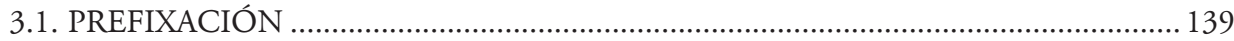

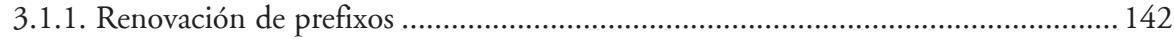

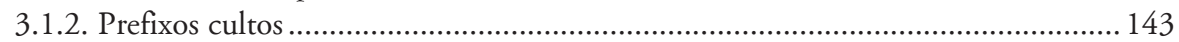

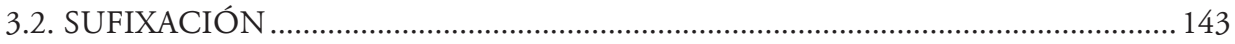

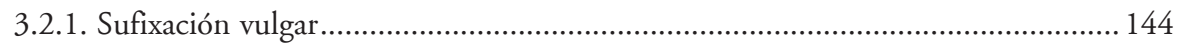

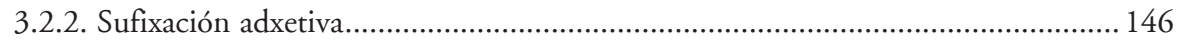

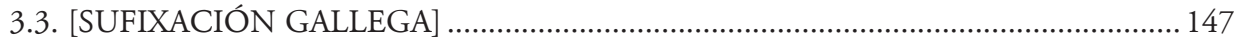

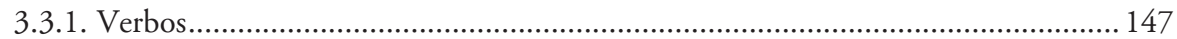

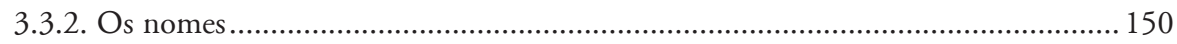

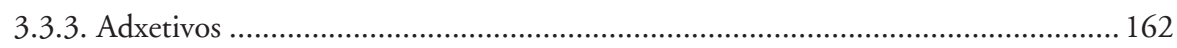

3.3.4. Derivación analóxica, [importada e regresiva] ................................................... 168

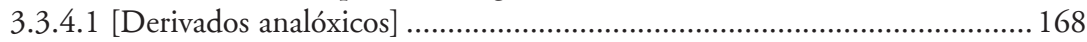

3.3.4.2. Sufixos importados............................................................................... 170

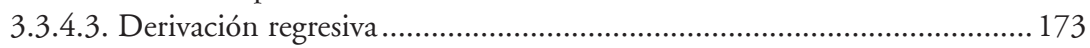




\section{A VIDA ÍNTIMA DAS PALABRAS}

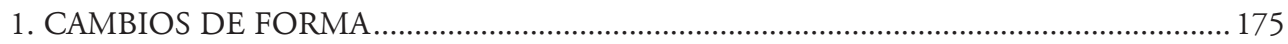

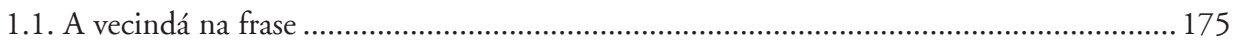

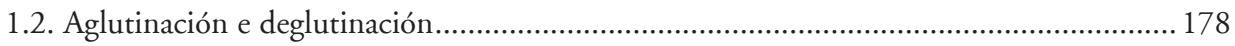

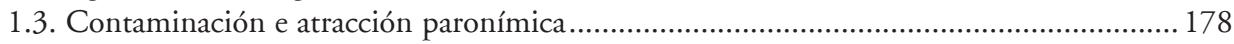

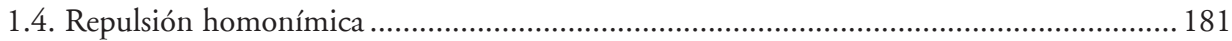

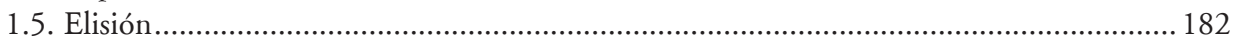

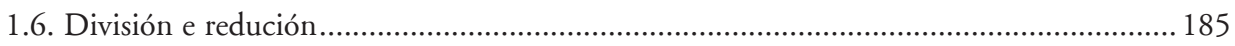

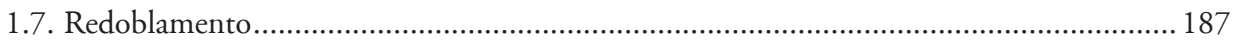

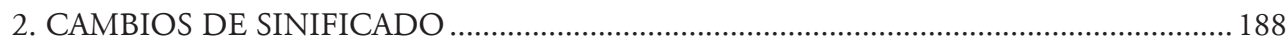

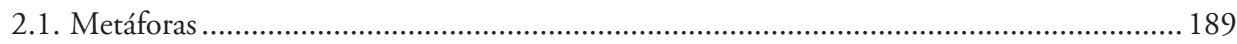

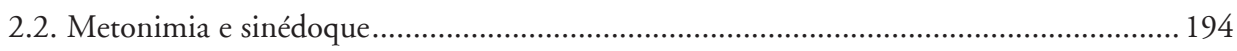

\section{A LENGUA, ESPELLO DA CULTURA E DA SENSIBILIDÁ}

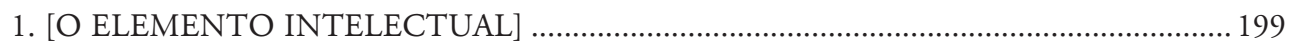

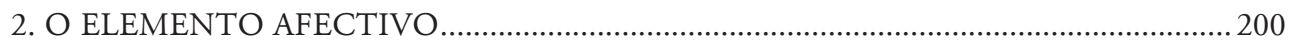

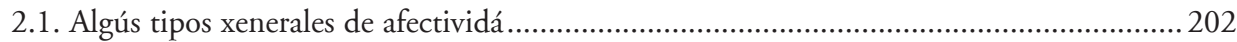

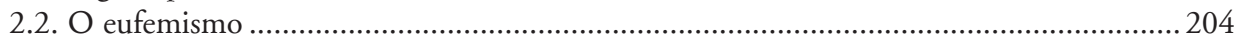

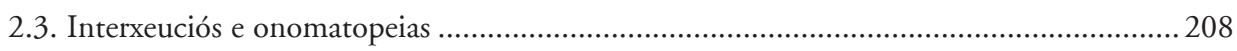

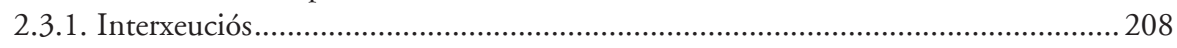

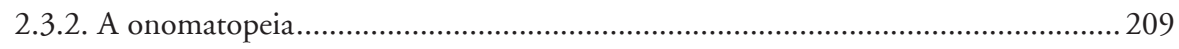

\section{A LENGUA, ESPELLO DA HISTORIA}

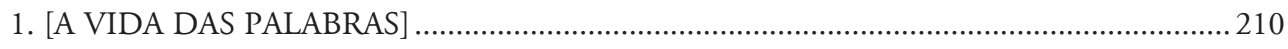

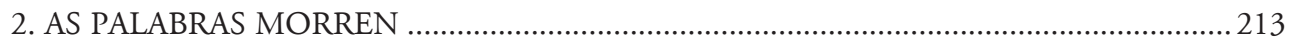

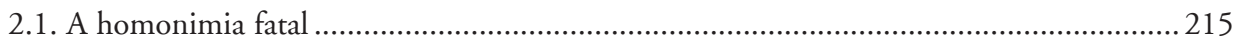

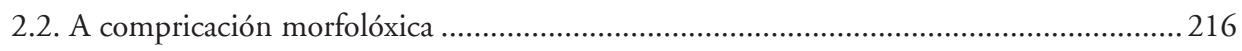

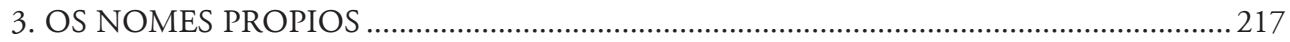

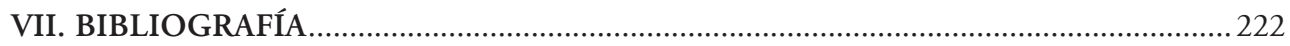




\section{I. [O CAMIÑO HISTÓRICO DA LENGUA GALLEGA]}

\section{INTRODUCIÓN}

Ven o gallego do latín trasplantado á Galicia. A romanización comenzóu ó longo das calzadas, en contados puntos do recorrido, como nos marcan os restos con que contamos, dos que falta aínda un corpus orgánico. Nestes puntos, onde acamparon xentes xa romanizadas, lexionarios vellos, comerciantes, xudéus, e un que outro manate do país, a romanización foi dun día pra outro. Non temos noticias de que houbese escolas, pero a presencia dun movemento cultural tan forte coma o que en Galicia houbo pouco tempo despóis, dinos moito do nivel dos colonizadores.

Ó redor había moitos montes e valgadas e neles, escondidas, as tribus anucidas dos gallegos. Plinio dá o número de 347.000 almas pra os dous conventos xurídicos de Lucus e Braga, divididas en 42 tribus. Murguía ${ }^{1}$ xoga con esta cifra de Plinio e fai chegar os habitantes de Galicia á máis de dous millós. Quizaves non teña razón; pois o censo de Domiciano do ano 86, en que puidera basarse Plinio, era xeneral, sin distinción de seso nin edá.

A romanización destas xentes foi moi lenta, e quizaves que non se cumprise hasta despóis das misiós de S. Martín de Dumio.

A falla de toda cras de material lingüístico sobre este punto non permite dar nada como certo. De todas sortes, non hai rastros de que a lengua ou lenguas prerromanas do país tiveran o menor xogo na vida intelectual. Por ningures se fala destas lenguas, como non seña nun texto ben conocido e pouco de fiar de Silio Italico ${ }^{2}$. Nin temos siquera unha glosa catequística, nun país de tan longa e persistente evanxelización.

1 M. Murguía, Historia de Galicia $\mathrm{II}^{2}$ páx. 455.

2 Sil. Ital. Bello Punico lib. III. 
A chegada dos Suevos fixo adiantar a romanización, ó estendela por todo o país cos novos asentamentos. Pasado o primeiro intre caótico, no tempo que vai entre S. Martiño e S. Fructuoso, fálase latín por toda Galicia, toda ela sementada de vilas labregas. Neste punto, poñamos o ano 700, conta cun fondo común de romanidade que, según o dito de Otero Pedrayo, ven á ser o mismo que de cristiandade. Os amoreamentos de gallegos, romanos, suevos e godos, presentes aínda hoxe nos topónimos, que, no seu tempo, deberon ser verdadeiras illas lingüísticas, fóronse estendendo ó redor dos bispados e dos grandes mosteiros. A xente das vilas e aldeas (deixando a un lado a fusión de razas e as divisiós de aquelas sociedades de manates, homes libres e servos $)^{3}$ fundíase linguísticamente no vivir de cada día, que a misma decadencia dos tempos igualaba; no vaguear que esprica un tempo de revoltas e inquedanzas, e, sobre todo, no enxameo monacal, verdadeira represa das augas revoltas do tempo.

Hasta este intre, o latín de Galicia non parece que teña sido moi distinto da koiné da Romanía.

A partir do ano 716 rompeuse fondamente a uniformidá lingüística e social que se viñera operando. Comenzaron á chegar primeiro as mareas de fuxitivos do Sul e, afirmado que estivo o pequeno reino de Asturias, viñeron os novos asentamentos, que se estenderon por todo o país. O número de servos viuse arrequentado con prisioneiros da Reconquista. As loitas dos vellos e novos señores entre sí e cos novos reises de Asturias, e as dus e outros coas xentes das fronteiras, foi parte esencial, ó longo dos tres primeiros siglos da Reconquista, do calado fermentar gallego. Á partir do ano 1000, estaba rematado o proceso esencial da lengua. Co novo milenio, éntrase nun tempo de relativo repouso social. Os grandes mosteiros e señoríos afincan á terra unha población meirande que nunca e gánanse pra o cultivo grandes ermanzas. A pelerinaxe á Santiago e a devoción santiaguista en xeneral, foi unha cal centralizadora que temperóu os centros de dispersión dos coutos de cada mosteiro e señorío. O mosteiro, de por sí, era xa un elemento regulador, ó estender por toda Galicia un módulo de vida labrega máis ou menos común. El rexía e dirixía esta vida labrega dentro dunha

\footnotetext{
3 A. Lopez Ferreiro, Galicia Histórica, páx. 673 e R. Prieto Bances, Historia de España III páx. 185 e outras.
} 
vía de longa tradición romana. E, como a gran masa que esfendía rozas e facía rellas e zocos veu a ser a cerna permanente de Galicia, o seu falar resultóu deste xeito a lengua común. É seguro que non faltan nela as súas variantes. Cando teñamos as monografías das lenguas das comarcas de Meira e Samos, Oseira, Acibeiro, Sobrado e Armenteira, e as dos grandes señoríos e vilas, atoparémonos, sin duda, con pequenos circos lingüísticos que hoxe non facemos máis que adiviñar. A lengua labrega, pegada ás cousas e ós usos e xeografía de cada terra, e xaramolada de tan distintas capas de romanización como as que nela actuaron, sin outra forza niveladora que as que levamos apuntadas, non podía ser de outro xeito.

É unha lengua esencialmente falada, porque a vida labrega non ten grandes héroes nin grandes feitos que contar e porque a cabaleiresca gallega, ou ben se enrola na gran epopeia hispánica, ou non pasa do ras da vida labrega. É, por outro lado, unha lengua concreta, manca de toda abstracción, debido á que a vida relixiosa que rexíu Santiago e os mosteiros de Cluny e Claraval se desenrolóu toda no vello latín, que no camiño de Compostela mantivo hasta o cabo a súa misión ecuménica. Ben por esta razón ou por unha tradición mozárabe que recolle Alvaro Cordobés e cita o Padre Sarmiento ${ }^{4}$, o caso é que ningún concilio mandóu predicar en romance. Debido á todo esto, a lengua gallega desta data vese privada do lésico épico cabaleiresco e, sobre todo, do lésico abstracto que a lengua relixiosa fixo nacer nos romances hirmaos, limitándose ó lésico rural e mariñeiro e ó da vida íntima e familiar, sin recobrarse nunca desta eiva do comenzo.

No siglo XI e XII debemos poñer o alborear literario do gallego. A esistencia dunha literatura popular, tan latina coma a misma lengua, parece probada en Galicia desde a época visigótica. S. Valerio fala dun clérigo berciano que andaba de porta en porta cantando versos, nin máis nin menos que un segrel, unha palabra que, coa de xuglar, veu á sustituir a de ludio pra sinificar o mismo oficio.

Hai quen pensa nunha tradición autóctona que remontan ós hinos priscilianistas e aínda ós cantos de guerra dos gallegos, de que fala de memoria Silio Itálico. Eu penso que se non poden encadear estes feitos e que a tradición latina

4 P. Sarmiento, Memorias para la historia de la Poesía (Buenos Aires, 1942) páx. 82. 
é sin duda a máis clara. Os clérigos aprenden como poden o seu latín, coa retórica e poética da tradición, inda que perdéndose nela e sentindo o engado das formas populares da métrica vulgar. As inscripciós latinas deste tempo aínda tentan as formas consagradas do dístico elexíaco, pero prefiren as formas populares rimadas que atopamos nas cruces de consagración da Catedral de Xelmírez.

Como naceron as escolas de troveiros e segreles no remuíno de xentes e culturas destes tempos é cousa aínda debatida e que debemos comprender como produto comprexo do tempo 5 .

Nos siglos XIII e XVI aparece o gallego como lengua literaria e notarial. Contra o que dixemos da lengua común ou falada, presenta ésta unha relativa uniformidade lésica, morfolóxica e sintáctica. Tentouse ver nela unha lengua de oficio, zurcida sobre unha tea provenzal pra o caso dos Cancioneiros e de baixo latín pra o da lengua dos notarios. Nos derradeiros tempos téndese á resaltar o elemento popular das cantigas dos segreles e trovadores, moito máis numeroso do que se pensaba nun comenzo ${ }^{6}$.

Sin entrar no fondo da cousa, nosoutros partimos do feito ben sabido de que o trovadorismo foi unha moda cortesana, coma as xustas e os torneos. Nesta moda eran elementos dados o escenario cortesano, a lengua e certos temas fixos e formas métricas. Esta razón fixo que o gallego fose nas cortes peninsulares a lengua de moda dos trobadores, que botóu fora a de $o c$ por razón natural e inda quizaves por outras razós extralingüísticas.

O gallego que, desta maneira subía á lengua poética peninsular, pra cumprir co seu, tiña que botar á un lado gran parte dos seus particularismos. Suprime a lengua labrega e dos oficios, que non viña á conto. Reduce á unidá os principales fenómenos fonéticos e morfolóxicos sobre a base do latín, galleguiza un que outro neoloxismo e usa os provenzalismos que a moda trovadoresca impoñía.

Era, deste xeito, unha lengua esquematizada, pero non máis que outras lenguas literarias, cando servía de istrumento á segreles gallegos. Na mau da turba de trovadores cortesanos, vidos de tódolos cabos da Península, é visto que non podía pasar dun pensum de escola.

\footnotetext{
5 M. Rodrigues Lapa, Liçoes de Literatura Portuguesa (Lisboa 1934) páx. 67 e sgs.

6 Rodrigues Lapa, Liçoes (n. 5) 167.
} 
Como a razón de ser desta lengua era esterno, a moda cortesana, e non tiña un soporte tradicional tan forte como se dí, rematóu onde tiña que rematar ó esmorecerse a moda que lle dera vida.

A lengua notarial, nacida por necesidades vivas de relación, desaparecéu detrás da trovadoresca cando a de Castilla se convertíu en lengua oficial de Galicia. Non houbo loita ningunha. Convertido Santiago dende o tempo dos Fonsecas en centro humanista, tributario de Salamanca e Alcalá, e seguindo o seu rumbo outros centros, como Monforte, Monterrey e Tuy, non tardóu en desaparecer o gallego escrito cos vellos notarios de vilas e mosteiros.

A partir do 1500, torna desta sorte o gallego á ser o que fora nun comenzo: a lengua da Galicia rural e mariñeira, menestral e doméstica. $\mathrm{O}$ novo mundo e a nova vida civil, política e relixiosa abríu as portas á lengua castellana.

Os historiadores da literatura gallega lograron atopar algunhas produciós gallegas dos siglos XVI, XVII e XVIII. É un labor de mérito, pero que non demostra nada. A verdá é que en todo este tempo se asentóu sobre o afán da superación da lengua do país todo ideal de vida mellor. E a volta ó gallego do XIX non é realmente un movemento que parta dos elementos internos da lengua, senón un movemento de retorno polo camiño da lengua de Castilla.

Debido á todo esto, a unidade lingüística, artificiosa e todo, que se fixera do XII ó XV desaparecéu, ó desapareceren os centros reguladores da actividá trovadoresca e dos escritorios notariales. Os escritores que aparecen do XIX pra acó escriben realmente no dialecto da súa comarca, sendo o castellano o elemento de unidá máis firme que os liga.

A penetración da lengua de Castilla, que ten no seu poder tódalas torres fortes é cada día meirande. A única defensa con que conta [o gallego] é o analfabetismo práctico da masa popular. Non se atopa un libro no noventa por cen das casas de Galicia nin se le un xornal. É unha defensa ben triste, de xente sitiada, pois que si non entra o enemigo tampouco se poden recibir os reforzos que sinifican as obras literarias con que milagrosamente se conta. Pra ben de Galicia, eu quero crer que non tarde en virse abaixo este castelo de inorancia. Penso pra daquela unha ascensión no nivel de ilustración das nosas aldeas, que se acompase co vivir rural e que non bote fora, como agora acontece, ós poucos afortunados que saben ler e escribir. Neste intre poden irse ó fondo moitas cousas. Pero eu fío no sino do gallego, que é o do retorno. Como se renovóu pola volta do 
romanticismo de Castilla, superándose a lírica dos Cancioneiros, agardo pra a lengua gallega un ollecer vizoso tras da onda ilustradora dos novos tempos, que non tardará en chegar ó derradeiro curuto na pleamar brilante da lengua de Castilla.

Pensemos no renacer da lengua catalana, e sobre todo nos grandes centros gallegos de emigración, que son, ó mismo tempo, as agrupaciós de superior ilustración do país, ilustración recibida pola lengua de Castilla, e que as leva, con todo, á volver á lengua do país pra dar nela saída ó máis íntimo do seu ser.

\section{O ESTUDIO DO GALLEGO}

Tódalas lenguas comenzaron á ser estudiadas no seu aspecto lesicográfico e gramatical, que é o que máis interesa nos intres de espansión. O gallego, que non conocéu ese intre, conocéu un movemento importante en relación co seu lésico e gramática, debido, como xa dixemos, á un sentimento de retorno á lengua nutricia, que se operóu e sigue operando en algús gallegos cando, ó traveso do latín e da lengua de Castilla, se dan conta do valor da propia.

Os primeiros traballos sobre o gallego datan do dezaoito, de Fr. Martín Sarmiento, en concreto. O renacimento literario do XIX trouxo consigo as primeiras gramáticas e vocabularios ó xeito tradicional. No remate deste siglo chegaron a Galicia e á un número contado de xentes dúas novas que avivaron un tanto estes estudios. Unha foi a da aparición da lírica medieval gallega, desconocida había moitos anos, e que traiguía por diante unha problemática lésica, gramatical, estilística, métrica e histórica, e outra, a da nova cencia lingüística, que viña a poñer unhas novas bases pra o estudio dos fonemas e do vocabulario.

As escolas romanistas, empeñadas en erguer o gran mundo do Latín Vulgar sobre os restos das lenguas romances, contribuíron e están contribuíndo á montar sobre bases centíficas os estudios do gallego, que, en moitos casos, se viñan facendo con menos acerto que boa intención.

A ortografía, cencia madrugadora, conta con algún traballo importante, e non faltan algús de estilística e métrica, referidos case sempre ós Cancioneiros. Todo xunto non é moito. Val a pena, de todas as maneiras, facer un pequeno reconto. 
O primeiro traballo lesicográfico con que contamos non pretendéu ser outra cousa que un glosario pra uso particular dun señor que andaba por Galicia e non conocía a lengua do país. Este señor era o Bachiller Olea, natural de Villalpando e do servicio do Conde de Altamira, Alcalde Maior dos seus estados nos primeiros do siglo XVI. Era home lido e curioso, e, nos libros que lía, iba anotando as cousas que cada día lle chamaban a atinción. A morte da Condesa de Lemos, o nacemento do Conde D. Rodrigo Osorio, a seca de Galicia de 1539 e contos e baduadas con que lle iba a xente do país e que el tomaba ó pe da letra coma o de que había en Valdeorras unha mina de turquesas e que os nabos de Lugo eran tan grandes que os labradores se sentaban neles ó redor do lume.

Entre estas notas figura unha lista alfabética de cento cincuenta e seis palabras, anotadas no revés do mapa 68 da «Xeografía» de Ptolomeo que había na biblioteca do Conde de Lemos e da que el debía de valerse na súa función de preceptor dos fillos da Condesa Da Beatriz. Este libro foi parar á Biblioteca Provincial de Lugo. Alí foi dar con el José Filgueira Valverde, que o publicóu no ano $1947^{7}$.

Según Filgueira Valverde este vocabulario debéu ser recollido nas terras de Lugo polo ano de 1536. O máis impresionante del é o número de formas caducadas e en desuso que contén e que, de non tratarse dun repertorio de formas xa raras naquel tempo, faría pensar nunha renovación moi grande da lengua neses catrocentos anos pasados.

En 1863 publicouse na Cruña o Diccionario Gallego Castellano de Francisco Javier Rodríguez, presbítero, natural de Bermés, en Lalín e bibliotecario da Universidá de Santiago. Foi o primeiro de algún empeño e o que servíu de primeira pedra pra os que despóis viñeron. É obra póstuma. Dos traballos lesicográficos que tiña mandado o autor á revista La Galicia, sacóu o director desta, Antonio de la Iglesia, o dicionario. Rexistra máis de catro mil palabras, acompañadas algunhas de indicaciós lesicolóxicas e lingüísticas, non sempre acertadas.

No mismo ano apareceron os Cantares Gallegos, de Rosalía de Castro, cun glosario de 208 voces, e, no ano de 1864, o Compendio de Gramática

\footnotetext{
7 José Filgueira VALVERDE, «El primer vocabulario gallego y su colector el Bachiller Olea (c. 1536)», nos Cuadernos de Estudios Gallegos VIII (Santiago de Compostela 1947).
} 
Gallego-Castellana, de Francisco Mirás, con outro vocabulario de cerca de cinco centas. Estes dous vocabularios distínguense polo seu contido popular e vivo. Francisco Mirás chega á transcribir os matices fonéticos según o lugar en que fixera a recollida, cun novísimo sentido do seu labor, cousa que lle había de criticar Marcial Valladares.

En 1876 publica en Barcelona Juan Cuveiro Piñol un novo dicionario gallego-castellano. Di o autor no prólogo que recorréu case toda Galicia, pero que atopóu coa dificultá das moitas maneiras que hai no país pra decir a misma cousa e coa dos moitos sinificados, algunha vez opostos, que ten unha misma palabra. De todo esto deduce Cuveiro que non se pode facer un dicionario gallego como é debido, o que é natural nun home do seu tempo que pensaba unha cousa pra cada palabra e unha palabra pra cada cousa. Chegado o momento de facer o dicionario, Cuveiro prescindíu por demáis da lengua popular, tan compricada, levado polo prestixio da letra impresa ou siquera escrita. $O$ fondo lesicográfico de que se valéu foi, sobre todo, o dicionario de F. Javier Rodríguez, xa libresco por demáis, e canto arcaísmo diplomático tiñan dado a luz os eruditos do tempo e puido el recadar no seu oficio de xefe de negociado de Hacienda. Recolléu ademáis no seu traballo as palabras que estudian o P. Sarmiento e Juan Manuel Pintos Villar, e as que usan en algunha das súas poesías Rosalía de Castro, Alberto Camino, Benito Amado e outros escritores gallegos do tempo, sin esquencer as «Cantigas» de Alfonso X. Aparte o gran número de arcaísmos, chama a atinción neste dicionario que conteña tantas voces de Historia natural. Débese esto a que recolle moitas da Galicia Médica, de Ramón Otero, da Fauna mastológica de Galicia, de Víctor López Seoane; do Ensayo de una flora fanerogámica gallega, de José Planellas Giral. Outras fontes que el mismo cita sin nombralas son certos dicionarios antigos, castellanos, portugueses e franceses, algús tratados de paleografía, diplomas e escrituras de antes do XV. Todo esto nos avisa de que a súa intención era a de deixar un dicionario de arcaísmos pra uso de archiveiros e paleógrafos. Chega á tanto nesto que nos dá como gallegos os latinorios dos escribanos e convirte por arte de imaxinarias etimoloxías certos patronímicos e topónimos en apelativos. Deste xeito «Masma» é un arcaismo que sinifica manoseo; «Gajate», azabache; «Barcia», brezo, e así outros, cun empeño que merecía mellor pago. 
No ano 1884 sacóu Marcial Valladares o seu dicionario gallego-castellano que, sin saber do de Cuveiro, tiña xa rematado no ano de 1869 , antes de que viran a luz, como el nos di, O Tío Marcos da Portela, Espiñas, Follas e Frores e Saudades, de Lamas Carvajal, Aires da miña Terra, de Curros Enríquez, Follas Novas, de Rosalía Castro, Versos, de Pérez Ballesteros, Risas e lágrimas, de Marcos Santos, A Fonte do xuramento, de F. María de la Iglesia e Mesa Revolta, de Barcia Caballero. Todos estes libros apareceron entre o 1869 e o 1884 e o feito de anotar Valladares este dato próbanos que non utilizóu estas obras, quizaves por non volver á un traballo que dera por rematado.

Confesa o mismo autor que refundíu no seu dicionario o de Javier Rodríguez; os vocabularios de Rosalía de Castro e Francisco Mirás e que tomóu do de Cuveiro unhas duas centas voces. Con todo esto, coas palabras por el recollidas nas terras do Ulla e cun cento máis, recollidas por D. Gumersindo Laverde Ruíz, dinos que o deu por rematado cun total de máis de 10.600 voces definidas, 460 refrás, proverbios e decires, algús anacos poético de autores contemporáneos e 240 cantares populares.

Pasóu algún tempo sin que se pensase en facer outro dicionario. Rosalía de Castro volvéu á acompañar Follas Novas de outro pequeno vocabulario e eso foi todo o que se fixo hasta que no 1913 se publicóu o primeiro coaderno do Diccionario Gallego-Castellano de la Real Academia Gallega. Este dicionario, feito sobre os que había e sobre aportaciós de algús académicos, como Leiras Pulpeiro, publicóuse regularmente hasta que morréu o bibliotecario da Academia, Florencio Vaamonde, que, ó parecer, era o seu verdadeiro autor. Quedóu parado na voz CATivo, e, no que vai feito, aspira á ser un dicionario de autoridades. Procura recoller mellor que ningún outro os distintos sinificados e a fraseoloxía de cada palabra; pero continúa co defecto de ser moi libresco, cousa moi de notar tratándose dunha lengua en que o máis e o mellor non está nos libros.

No 1926 publicóuse como folletón no diario de Vigo El Pueblo Gallego un Vocabulario Galego-Castelán, colleitado por Filgueira Valverde, Tobío Fernández, Magariños Negreira e Cordal Carús. "O noso vocabulario», din os propios autores, «é unha sinxela recadádiva das verbas contidas nas obras de Sarmento, nos Diccionarios de Rodríguez, Cuveiro, Valladares, no que vai publicado da Academia e no vocabulario anónimo publicado por Leite de Vasconcelos, nos glosarios dos cancioeiros e demáis obras clásicas galegas, nos papéis inéditos de 
Saco Arce, nos documentos, nas obras dos escritores contemporáneos e nos beizos do pobo».

Sin vir tampouco a cabo, chegóu, con todo á letra $U$, e, si se editara como era debido, tería a súa importancia. Ten de novedá o feito de presentar un sinnúmero de neoloxismos analóxicos, non rexistrados en ningures e sigue a tradición de dar preferencia á formas históricas vencidas.

Moi polo estilo deste, aparecéu en 1928 na Cruña, en dous tomos, o Diccionario Galego-Castelán de Carré Alvarellos. Tivo segunda edición en 1931, e, como herdeiro dos anteriores, é o máis comprido de todos eles. Arrequenta o seu vocabulario, as súas virtudes e defectos. Neste intre está en vías de reedición, e, ó parecer, moi anovado.

O derradeiro en aparecer hasta este intre foi o Diccionario Galego da Rima e Galego Castelán de José Ibáñez Fernández, publicado en Madrí en 1950.

Aparte a distribución do lésico, sigue moi de cerca ó de Carré, inda que recolle moitas formas vivas das terras de Monforte e ten algunhas outras cousas de proveito.

Fora destes traballos de conxunto, hai os vocabularios das Cantigas de Santa María (Madrid, 1889), do Cancioneiro de Ajuda, debido a Carolina Michäelis de Vasconcelos (Revista Lusitana, 1920), do Cancioneiro da Vaticana (Lisboa, 1878), da Crónica Troyana (Coruña, 1900), das Cantigas d'Amigo (Coimbra, 1928) e outros de poetas soltos dos Cancioneiros e de Antoloxías, coma os de López Aydillo (Madrid, 1914), Armando Cotarelo Valledor (Madrid, 1934), Fernández Pousa (Madrid, 1951) e Álvarez Blázquez (Vigo, 1952). Todos veñen acompañando as ediciós de obras á que se refiren, sin comentar máis que os arcaísmos.

Na revista Nós de Ourense, que deixóu de publicarse en 1936, e nos Cuadernos de Estudios Gallegos, que hoxe publica o Instituto P. Sarmiento de Estudios Gallegos, apareceron algús vocabularios de comarcas. Moitas veces limítanse a listas de voces raras, pero de proveito sempre.

Outros traballos de lesicoloxía serán anotados máis adiante polo seu carácter especial.

A gramática nacéu tamén co renacemento literario do XIX e foron os primeiros estudios sobre este punto o Compendio de Gramática Gallego-Castellana de Francisco Mirás (Santiago, 1864), El habla gallega de Juan Cuveiro Piñol (Pon- 
tevedra, 1861), a Gramática Gallega de Juan Saco y Arce (Lugo, 1868) e a Gramática do Idioma Galego, de Manuel Lugrís Freire (Coruña, 1922)

O máis interesante, con moito, de todos estes estudios é o de Saco y Arce, polos moitos fenómenos que señala. A de Lugrís é por demáis normativa e ordenancista, feita, por outro lado, sin o acopio de datos que precisa unha gramática.

Ó calor do descobrimento dos Cancioneiros e dos novos principios lingüísticos escribíu Vicente García de Diego os seus Elementos de Gramática histórica Gallega. Fonética-Morfología (Burgos, sin data), que é o traballo histórico de conxunto máis serio que se ten escrito ó redor da lengua gallega. Sobre esta obra e outras portuguesas que cita, publicóu Couceiro Freijomil unha Sintesis de Gramática histórica que figura no seu libro El Idioma gallego. Recóllese nela toda a labor de investigación das obras xa indicadas.

Vicente García de Diego no seu Manual de Dialectología Española (Madrid, 1946) refunde con algunhas anovaciós a súa primeira obra.

Sobre a lengua dos Cancioneiros, en concreto, son importantes os comentarios lingüísticos de J. J. Nunes que acompañan as ediciós das Cantigas d'Amigo (1928) e das Cantigas d'Amor (Coimbra, 1932); os de Gassner sobre a lengua do Rei D. Diniz (1907) e os de O. Nobiling sobre o texto e interpretación do Cancioneiro de Ajuda, sin esquencer nunca os traballos de Michäelis de Vasconcelos e outros moitos de estudiosos da nosa lírica medieval, que, inda que circunstancialmente, tratan os problemas lingüísticos e filolóxicos que presenta.

Sobre distintos aspectos históricos do gallego escribíu o P. Atanasio Lopez, «Gallego y Portugués», un pequeno traballo aparecido no Boletín da Academia Gallega (t. IX, páx. 145-147), Andrés M. Salazar (Coruña, 1907), «Apuntes acerca del origen e historia del artículo gallego-portugués», Manuel R. Rodríguez, «Apuntes gramaticales sobre el romance gallego», publicados ó frente do tomo I da Crónica Troyana (Coruña, 1900), e aínda outros autores, non sempre dinos de terse en conta.

Sobre o gallego actual aparecéu en 1906 a Morfología del gallego moderno de J. Cornu, traducida e publicada por F. Martínez Morás en 1909. Non conocemos outra obra de conxunto. Pero de algún tempo a esta parte fixéronse sentir no país as escolas xermánicas de etnógrafos e romanistas, que teñen por precursor ó P. Martín Sarmento, un raro fenómeno de intuición lingüística, sobre todo no seu Onomástico etimológico de la lengua gallega. Sin outra intención que a 
puramente lesicográfica traballaron os mindonienses Leiras Pulpeiro e A. Noriega Varela.

O primeiro non deixóu publicado máis que algunhas colecciós de refrás, aparecidas no Boletín da Academia Gallega. O segundo, Como falan os brañegos (Santiago, 1928), un curioso repertorio de ditos, acepciós peculiares, refrás e adiviñanzas. É do mismo tipo o Vocabulario gallego de Moura, publicado por Antonio Villagarcía (C.E.G., III, Fasc. IX). Outra cousa son os traballos de W. Ebeling sobre a lengua do levante de Lugo e os de Fritz Krüguer sobre a de Sanabria, á tenor dos que se levan feito moitas tesis doctorales, inda que ningunha en Galicia.

Os traballos máis recentes sobre a lengua gallega versan sobre os nomes propios, topónimos particularmente. Débenselle, en gran parte, ó profesor de Coimbra, Joseph M. Piel, que leva estudiados os topónimos xermánicos en Galicia e Portugal, os de posesores latino-cristianos e os dos santos tradicionaes hispánicos. Débeselle ó Prof. Abelardo Moralejo Laso o estudio dos topónimos en -OBRE, así como o dos derivados de FONS e FOGIUM. Sobre o mismo asunto, inda que con outro método, teñen traballado Florentino Cuevillas, Narciso Peinado, Víctor Olano Silva, Buenaventura Cañizares, Ramón Fernández Ojea e Manuel García Blanco.

O mismo interés que polo estudio de topónimos e antropónimos, despertóuse nos tempos que corren polos etimolóxicos e lesicolóxicos. Un modelo acabado deste tipo de estudios é o publicado en C.E.G. por Dámaso Alonso sobre a palabra ENXEBRE e aínda outros do mismo autor sobre distintas palabras. A contribución neste campo do Prof. Piel é, sin duda, decisiva. El solo leva traballado por todos. Manuel Díaz y Díaz, Aníbal Otero Álvarez e Isidoro Millán (fillo) publicaron tamén traballos importantes e son, hoxe por hoxe, a promesa máis $\operatorname{lograda}{ }^{8}$.

Sobre ortografía gallega debemos notar que se impuso por moito a das transcripciós dos Cancioneiros, toda ela presidida por unha estreita vixilancia das sinalefas. Esta ortografía levóu á moitos escritores á encher as súas obras de

\footnotetext{
8 Aníbal Otero Álvarez. Hipótesis etimológicas referentes al Gallego Portugués (CEG. Santiago de Compostela). Isidoro Millán Pardo publica un estudio etimolóxico de varias palabras, como epílogo á colectánea de cantares populares, Antifona da Cantiga, de Ramón Cabanillas.
} 
apóstrofos e guiós, que compricaban sobradamente a lectura. As cuestiós que máis se debatiron foron as referentes á representación de š ou Ch francesa. Desde o XIX hasta o ano 1930, veuse discutindo a tesis etimoloxista de representar ese son por $g$, $j$, ou $x$, según o orixen, ou por $x$ en tódolos casos, que foi a norma que parece ter trunfado. Os autores de gramáticas gallegas, como Saco y Arce, Lugrís Freire e Couceiro Freijomil, deron todos normas ortográficas que os escritores interpretan cada un ó seu xeito. O mellor traballo sobre este punto débese á Couceiro Freijomil e á Abelardo Moralejo Laso (Ortografía gallega. Bases para su unificación. Orense, 1930), que non tivo, con todo, a vixencia rectora que merecía.

Sobre a prosa gallega non se ten feito ningún estudio. Hai algunhas monografías sobre a lengua poética de Curros Enríquez e Rosalía de Castro, debidos á Ricardo Carballo Calero e Sister Mary Pierre Tirrell, e lévase escrito moito sobre os Cancioneiros, como atrás deixamos dito?.

9 Unha amplia bibliografía sobre este punto pode atoparse en M. RODRíGUEZ LAPA. Liçôes de Literatura Portuguesa, Lisboa, 1934, páx. 169 e en J. Filgueira VAlVERDE, «Lírica medieval gallega y portuguesa», páx. 628-642, dentro da Historia General das Literaturas Hispánicas, Editorial BARNA. Barcelona. 


\section{OS VOCABULARIOS}

\section{XENERALIDADES}

As palabras dunha lengua poden evocar cousas e ideas, representaciós dos sentidos e do intelecto, ou ser simples istrumentos gramaticales.

Nestes versos de Pondal:

Diráslle que unha de ferro arrastro rouca cadea (A Campana de Anllóns v.v. 46-47)

hai cinco palabras que evocan imaxes precisas: «decirlle», «[ferro]», «arrastrar», «rouca» e "cadea». As outras tres non sirven máis que pra espresar categorías lóxicas ou gramaticales.

Unhas e outras non se corresponden xustamente nunca cos seus sinificados. O valor de unha palabra varía dun día pra outro, pola sinxela razón de que son como traxes que han de vestir moitas xentes distintas. Unhas veces cárganse de sinificados, como lle pasa á palabra agulla, nestes casos: «coseuno á agulla», «non quere carne da agulla», "trouxo unha agulla a peixeira», «a agulla do viño de Betanzos», «fíxolle un pucho á agulla», "caeulle unha agulla da porta», "púxolle a agulla ó rodicio», etc. E outras valéiranse de sinificados, hasta quedarse cun solo, se cadra o máis estraño. A palabra «chama», de flamma, atacada polo castellanismo «llama»e os sinónimos «lapa» e «laparada», está hoxe á punto de desaparecer no seu sinificado primeiro manténdose pra sinificar cada unha das pedras que forman a bóbeda do forno.

«Orgo», de organu, tan chea de contido ideolóxico no seu orixe, non ten hoxe outro valor que o de «eixe en que se enrodela a tea nos teares da mao».

Nestes cambios de contido as palabras poden trocar de naturaleza. Os adxetivos fanse sustantivos, como lle acontecéu á «xornal»; frases enteiras, como «zarra buqueiros», pasan á espresar unha idea de cousa. Un nome propio faise 
común por moitas razós. Cando María Balteira pedía no seu testamento dez varas de Stamphon vermello pra cubrir o seu ataúde, convertía un nome propio en común. E nós facemos igual cando pedimos «un boleto de berlina».

As razós que esprican este contino movimento son moitas. $\mathrm{O}$ desgaste natural do valor espresivo das palabras, a tendencia á dar orixinalidá e viveza ós nosos ditos, a necesidá de dar nome á ideas e cousas novas, esprican, de seu, estes cambios e os constantes neoloxismos que van transformando as lenguas. Pero si nos fixamos máis concretamente na forma e individualidá das palabras, veremos que tampouco aquí hai nada que non esteña sometido á cambio costante. As flesiós verbales e pronominales, por un lado, e as contracciós, provocadas pola evolución fonética, por outro, atacan fortemente a unidá das palabras. En palabras como «dixérono», «vímolo», «nesto» e «nestoutro» non aparecen os elementos individuales se non é por un análisis de gramático.

Contribue tamén á esto a multiplicación das partículas de relación, que tenden á privar á palabra da súa independencia en proveito da frase. Na espresión «sano coma un buxo», o valor de «buxo» está íntimamente ligado á comparación.

A erosión da evolución fonética ten aínda outro resultado. As lenguas faladas repunan as palabras curtas, como nolo confirma o latín vulgar ó sustituir os por cara, equus por caballus, etc., como se ve polo gallego de hoxe, que prescindíu dos adverbios de lugar «y» e «en», dos que tanto uso facían os escritores medievales.

Como, debido ós desgastes da evolución histórica, moitas palabras quedaran curtas por demáis, o gallego deu entrada de boa gana á moitos castellanismos. Igual que outras lenguas, o gallego busca as palabras de estructura fónica ben axeitada, nin por demáis curtas nin longas, e ben caracterizadas. En virtú deste principio a lengua reacciona por tódolos medios con que conta: préstamos, regresiós fonéticas, oscilaciós de pronunciación, variantes morfolóxicas, todo o preciso pra non caer na anfiboloxía. A caducidá de palabras como «áa», «al», «ar», «des», «dy», «noa», «saar», «soo», e outras, pende de aquí.

Son aínda outras moitas as causas que interveñen no costante ir e vir dunha lengua. $\mathrm{O}$ estudio cabal do seu vocabulario é o que mellor nos enseña as repercusiós nela dos acontecementos históricos da xente que a fala. Pero os fenómenos son tan intrincados neste punto que nosoutros non podemos facer outra cousa que caracterizar en poucas palabras as distintas épocas. 
O vocabulario do latín vulgar distínguese do do clásico pola espulsión de arcaísmos, verbos irregulares e partículas monosílabas e pola preferencia que dá ós derivados, ós tecnicismos, ás palabras longas e ás formas compostas dos verbos, dos adverbios e formas determinativas. Outra das características é a multiplicación de neoloxismos. Aparte o número de palabras prelatinas que en Galicia puidera incorporar, o latín da nosa romanización estaba invadido de grecismos técnicos, industriales e comerciales. Dous grandes feitos favoreceron a súa renovación. En primeiro lugar a evanxelización, que trai consigo novos helenismos e fai desaparecer unha parte do vocabulario pagano, e, en segundo lugar, as invasiós bárbaras, non precisamente polas novedades que trouxeran, senón polo principio de dispersión e acantonamento que introduciron.

O resultado da invasión dos Suevos foi un empobrecemento da lengua abstracta, do que o gallego non se curóu. A época da Reconquista acentuóu aínda os feitos. A lengua empobrécese de día en día en palabras abstractas, mentras que se enriquece en tecnicismos e se desfigura cada vez máis no seu fonetismo e morfoloxía. Os desplazamentos dos siglos IX e X, asentamentos e repoblaciós, esnaquizan por comarcas o lésico, como inda hoxe se pode comprobar na misma lengua común.

O gallego perde neste intre as últimas amarras que o puideran ter preso ó latín. Coa reforma cluniacense do siglo XI o latín pasa á ser unha lengua case morta, diplomática; pero o seu renacimento había de ser proveitoso pra o gallego. Os estudiantes que iban e viñan a Francia e Italia levantan o mellor monumento literario nas formas recén nadas do gallego, con que esta lengua había de contar en moito tempo. Aparte as súas raíces máis ou menos populares, a lengua dos Cancioneiros mantén a unidá e independencia de cada palabra como o non podería facer sin a pauta do latín culto. De ahí a libertá que mantén no orden de colocación das palabras, á costa da claridá moitas veces, de ahí a sutileza dos conceptos, montados sobre un xogo esquemático e gotizante de pronomes e adverbios armónicamente situados, moi lonxe das firmes apoiaturas románicas da lengua vulgar.

É Bernardo de Bonaval, o máis vello segrel conocido e o máis enraizado na vida popular, á xuzgar polo que del sabemos. Con todo eso, é o autor desta estrofa, onde se pode ver todo o que acabamos de decir. 
E se vós, filha, meu amor queredes rogo-vos eu que nunca lhi faledes sem mi, ay filha fremosa. E al ha hi de que vos non guardades: perdedes hi de quanto lhi non falades sem mi, ay filha fremosa. (C.V., 735, vers. 4-9)

A segunda estrofa está toda ela montada sobre as resonancias vivas do latín do tempo.

A lengua popular, que non conocemos propiamente, porque non podemos tomar por tal a dos tradutores e notarios do tempo, tivo que sufrir no siglo XIII un arrequecemento grande, debido ó pulo que tomóu a Reconquista e ás rutas cada vez mais longas que se abren no mundo despóis das Cruzadas e que poñen en comunicación a Europa toda co Oriente. Os gallegos figuraron en gran número na hoste de Fernando III, pero ademáis chegaban polo Camiño de Santiago moitas outras novedades de oficios e formas de vida, que tiveron que deixar na lengua os seus nomes.

O fin da Edá Media trougo pra o gallego unha crisis dobrada. A nova vida que consigo trai o Renacemento enterra moitos nomes de cousas, usos, e costumes que entón desapareceron. A sociedá señorial do noso XV, quebrado o réxime de vida que impuxera á punta de lanza, desperdigouse por fora de Galicia, e nace un novo señorío de tipo oficial que fala castellano. O divorcio entre a lengua falada e a que se escribe e enseña é total de aquí en diante. A lengua labrega pégase cada día máis ós sucos. Medra en derivados e compostos e, sobre todo, en localismos que impoñen os distintos traballos de cada terra. O gallego pasa entón á ser sino de rusticidá. Coma o saiagües, é a lengua dos graciosos do teatro clásico español. En algús espíritus, con todo, é tamén a lengua en que fala Galicia. Por eso a lamentación de Galicia pola morte de $\mathrm{D}^{\mathrm{a}}$ Margarita de Austria (1611) ven escrita en gallego, e, pola misma razón, o soneto de homenaxe a Ercilla de $\mathrm{D}^{\mathrm{a}}$ Isabel de Castro (1589), o Romance das Festas Minervales, de J. Antonio Torrado, en honor de Fonseca (1697) e aínda os poemas que o Cura de Fruime dedica a Rajoy e á Marquesa de Camarasa. Este poeta, por eso, como Feixóo e Sarmento, escribe en gallego pola súa postura polémica na loita que tiveron que librar os escritores gallegos, desde Pedro Fernández de Castro, contra 
as burlas dos escritores de Castilla. Esa foi a raíz máis fonda do movemento literario do XIX, reforzada polo levantamento popular deses tempos e as novas ideas románticas, que viñeron a valorar en todas partes os elementos arcaicos e populares, e, sobre todo, a espresión viva, frente a forma academizante.

A lengua falada viñera creando gran número de espresiós literarias, debido á milagrosa pervivencia de certas formas populares como a cantiga, o cantar de pandeiro, os escarnios de antroido, os maios, os parrafeos ou retesías, os cantares de cego e os de traballo. Sobre estas formas alzouse a primeira poesía de Rosalía de Castro, nunha lengua purísima de estructura, pese ós castellanismos lésicos, que non fán máis que asegurarnos da súa autenticidá. Outros escritores do renacimento galleguista, non por certo os mellores, buscan nesta misma lengua falada, nos seus ditos e retorneos, o medio de espresión pra relatarnos as costumes do país.

Os poetas máis intelectualizados botan mau das formas literarias de Castilla, traducidas ó gallego, e fan uso ademáis, como é natural, de todo o lésico abstracto de que éste carece.

A partir do 1900, a presión que o castellano ven facendo sobre o gallego acréceuse pola emigración, as moitas escolas creadas e polo adianto xeneral das comunicaciós. Os utensilios da industria chegan a todas partes, e as súas produciós, co seu lésico correspondente. Médicos, abogados e mecánicos tran os tecnicismos do seu oficio. Con todo esto, non creo que perda nada o gallego, xa que unha lengua non é unha cousa estática que sufra coas variaciós, como sofre un monumento de arte. Respondendo á esta revolución que se operóu na lengua falada, deuse outra, de sentido contrario, na escrita. Os escritores víronse atacados na súa maior parte dun afán de arqueoloxía literaria e, poñendo en pe de repente tódolos arcaísmos e tódalas leises fonéticas que se deron no gallego, desde moito antes de ter éste esistencia, caducadas algunhas delas antes do siglo $\mathrm{X}$, e todas elas no momento en que vivimos, lograron crear unha lengua na que ninguén descubre un sólo préstamo castellano na súa forma esterna.

É unha maneira de enriquecer a lengua nin máis nin menos que a primeira, inda que por distinto camiño. 


\section{ESTENSIÓN E PROFUNDIDÁ DUN VOCABULARIO}

O vello Horacio comparaba a lengua á un arboredo no que cada primavera renóvanse os outonos perdidos. Víctor Hugo faino cun río, que corre sin parar. Calquera das dúas comparaciós é ben precisa. Calquera das dúas nos sirve pra ver que a historia de unha lengua, arrincando dun fondo primitivo de partida, non é outra cousa que a historia das súas perdas e a dos seus arrequecementos.

As perdas e arrequecementos dunha lengua poden caer sobre tres conxuntos de fenómenos, sobre os fonemas, sobre as formas morfolóxicas e sintácticas e o vocabulario. Por grande que seña o número de renovaciós que se teñen dado nos dous primeiros sistemas, son moitas máis as que se deron no vocabulario, pola razón evidente de que o vocabulario de unha lengua é un conxunto moito meirande de fenómenos. As palabras rexistradas nos dicionarios gallegos non creo que pasen de 15.000. Son un conxunto moi por enriba do que formarían os fenómenos fonéticos, morfolóxicos e sintácticos xuntos. De calquer xeito, este número non nos dá nin con moito o verdadeiro volume do vocabulario gallego, cos distintos valores e acepciós de cada palabra. Realmente, non temos un dicionario do gallego medieval. Apenas hai documento que non conteña algunha palabra inda non recollida, xa non digamos esplicada. Nun documento publicado por Murguía en 1907 e reproducido por Couceiro Freijomil no seu libro El Idioma Gallego, figuran «cazún», «cazuaban», e «porcador» que non vin recollidas en ningún vocabulario. Como estas tres, hainas á centos. Do gallego moderno tampouco se pode decir que o temos, porque, nos que hai, está moi lonxe de recollerse a inmensa riqueza de localismos técnicos e variantes semánticas de cada comarca, nin pode facerse siquera. O día que se tiveran recollidas por tempos, tódalas voces gallegas históricas e os seus distintos valores e acepciós, non sería moito decir que pasarían de trinta ou corenta mil. Neste número figurarían moitas comús ó castellano, nesta ou na outra acepción; pero non serían menos gallegas por eso. Lenguas hai que apenas si conservan media ducia de palabras do seu lésico orixinario, sin confundirse por eso con ningunha outra lengua.

Aparte de ser moitos máis os fenómenos lésicos que os fonéticos, morfolóxicos e sintácticos, están moito máis espostos á variación. Estas frases do siglo XIII, "se non dádem' á morte», "diréivolo eu», "poilo non sabedes», non sufriron o menor cambio fonético morfolóxico nin sintáctico desde que foron acuñadas. 
Pero si damos á ler á un gallego de cultura media o soneto Respice finem de Vázquez de Neira ou o Vocabulario do Bachiler Olea, interpretará mal, ou non interpretará, moitas das súas palabras.

O estudio dos arcaísmos e neoloxismos lesicográficos dunha lengua é, por todas estas razós, a parte principal da súa historia. A maioría dos fenómenos fonéticos, morfolóxicos e sintácticos danse moito antes de que se teña concencia da nova lengua.

O notario do siglo X que escribía «e inde quomodo descendit ad cabeza do rego da pena de Trastao» estaba ben seguro de escribir en latín, polo feito de conservar «inde quomodo descendit» na forma adeprendida na escola e que non era a do romance, sin darse conta das demáis variaciós, que non pasarían de ser faltas normales, inda pra os máis avisados. Os cambios de vocabulario son outra cousa. A introdución de catro localismos ou arcaísmos nunha páxina escrita en gallego fai decir á moitas xentes de mediana cultura que ven escrita en portugués, e á asegurar, por de pronto, que aquelo non é gallego.

\section{Características dun vocabulario}

A decir verdá, nosoutros non conocemos ben máis que o noso vocabulario. Mismo que seña unha lengua viva e de hoxe coma o gallego, componse de moitos vocabularios particulares que non é doado conocer nos máis secretos matices. $\mathrm{O}$ vello dito de somos gallegos e non nos entendemos, trocado modernamente en somos gallegos e ben nos entendemos, encerra nos dous casos moita verdá. O gallego de hoxe, coma o de sempre, componse dunha lengua común, na que se espresan ideas de cousas, coalidades e auciós correntes, como "pan», "carne», «viño», «leite», «branco», «negro», «mouro», «verde», «maduro», «ir», «vir», «andar», «comer». Inda nesta lengua hai as súas variantes pero, de calquer xeito, non hai ningún gallego-parlante que as desconoza.

Fora deste vocabulario común hai outro técnico, pra desinar os avíos de labranza, a anatomía e fisioloxía de personas e animás, a fauna e a flora, os distintos labores, sazós e modos, e todo esto queda fora da comprensión do gallego de cultura media e inda máis. Esto polo que se refire á lengua falada, que a lengua escrita, sobre todo a de hoxe, tende á incorporar á técnica neoloxismos, arcaísmos e xiros estraños á lengua común, que fan dela un exercicio de esforzo 
de comprensión, inda pra os espíritus mellor cultivados. Unha páxina de Otero Pedrayo ou Carballo Calero é unha proba desto, que pasa en gallego como en calquer outra lengua de hoxe.

O vocabulario, pois, dun gallego parlante está formado polo vocabulario común e polo vocabulario ou vocabularios técnicos do seu oficio. É tan variado como variados son os oficios e as ocupaciós dos individos, cambiando moitas veces coa edá e coa ilustración de cada un. Fora deste vocabulario, que é o propio, tense outro, mais ou menos rico, de palabras que entendemos pero que non usamos ou que usamos mal. É o caso dos nosos paisanos en relación co castellano común e co vocabulario técnico de outras comarcas de Galicia que non seña a súa.

Dentro do vocabulario de cada individo cabe aínda distinguir duas series de palabras. Unha, de palabras secas e desoradas, e outra, de palabras cargadas de burla, de mimo, de humor. Si nunha taberna dá de disculpa pra se ir un dos contuberles que "que lle reñe a muller», «que lle reñe ela», "que lle reñe a súa dona», "que lle reñe a súa andosca» refírese sempre á misma cousa, pero con matices moi distintos. Por enriba de todos estes tipos de vocabularios, quedan aínda as palabras máxicas e as palabras de moda. As primeiras son case sempre cultismos ou tecnicismos mal entendidos que o din todo e que non dín nada. Eu recordo que a palabra «aléutrico» andivo moi corrida pra denotar ademiración. "Déixasme aléutrico ou aleuto», decía a xente. Outra palabra máxica foi «estraperlo». Na lengua escrita aparecen tamén moitas palabras máxicas, que non tardan en desaparecer, pero que teñen outro orixen. As palabras de modas ou clases de texidos son aínda moito máis efímeras.

Do conxunto do vocabulario fanse aínda outras divisiós según estamentos.

Hai palabras de boa e de mala crianza, bocaladas, velliños de costureira e latixos. Unha persona ben falada non usa nunca certas palabras. A un vello, ou nada máis que maior, non se lle debe contestar «non», á secas. «Non señor» é a resposta de boa crianza. As bocaladas xa se sabe o que son e non forman parte máis que do vocabulario de xentes ruís. Os velliños de costureira son palabras escollidas propias do vocabulario das mociñas, frecuentemente castellanismos, coas que evitan outras que se lles antoxan vulgares. Decir «apetito» en vez de gana, «craviel» por «cravel», «horquilla» por «furquita» son velliños, remilgos, que a xente nota e chotea algunhas veces. Latixo vale tanto como lengua argótica. É a 
que usan os nenos da escola, os mozos que andan de ruada e sobre todo as xentes dun oficio. Nacen estes latixos da propensión natural á consina secreta. Ten certa importancia a derradeira, formada por un pequeno vocabulario de moi distinta procedencia, urdido na trama morfolóxica e sintáctica do gallego. $\mathrm{O}$ argot dos nenos e o da mocedá é moito máis sinxelo. Consiste o primeiro en separar as sílabas dunha palabra, antepoñendo a cada unha un mismo prefixo. «Deguedepá-deguedepá» sinificaba no meu tempo "papá». Hai outros procedementos, pero semellantes todos. $\mathrm{O}$ da mocedá consiste en cambiar de sinificación unhas cantas palabras claves. Noriega Varela na súa «De Ruada» danos algús exempros deste argot.

Desde un punto de vista estilístico hai quen tenta dividir tamén o vocabulario gallego en grupos de palabras poéticas, vulgares, locales, etc. Ten esto dous peligros. O primeiro é o de que non contamos cunha lengua literaria actuante como norma pra decidir, e o segundo que, a falta desta norma, tomaremos a do castellano que non nos sirve. Esta división, de facerse, debe ser tendo en conta a que eu chamaría lengua fidalga, representada hoxe en día polos curas ou abades de aldea, algús médicos vellos e pequenos señores de terras e lugares.

\section{Como se ordenan estes vocabularios}

As palabras que forman o noso vocabulario individual aparecen todas ordenadas en familias ou conxuntos no noso espírito. Non se trata de familias históricas á partir dun tema común, como aparecen nos dicionarios etimolóxicos, nin tampouco enteiramente de familias de sinónimos, como aparecen nos dicionarios ideolóxicos, anque hai algo desto último. Cando evocamos a idea de monte, non cabe duda de que veñen á nosa memoria con pouco esforzo as palabras «serra», "pico», «outeiro», "val», "chao», "veiga» e aínda outras, en circos máis ou menos apretados. Dunha maneira xeneral, sin embargo, as palabras viven en pequenas camadas, formadas por frases de uso diario. A palabra "fabieiro", non se atopa máis que na espresión "meteullo no fabieiro». "Candieiros», fora da lengua literaria, non se atopa tampouco fora da espresión, metafórica pra máis, de «ergueuse ós candieiros», e así "antano» en «vícheme aquí antano», «mao» en «ollo mao», «barón» en «a ollo de bon barón» e outros moitos casos dos que non cito máis que aqueles en que unha das palabras da frase está caducada como libre, para que se vexa ben a vitalidá destas familias. 
Este vocabulario vivo de que estamos falando está moi lonxe de confundirse co dos dicionarios máis completos. Unha palabra nun dicionario é algo morto, que non dá máis de sí; pero viva no noso espírito é unha fonte permanente de novas formas.

O mismo na lengua familiar que nas técnicas e, sobre todo, na literaria aparecen cada día novos derivados. Eu recordo a chegada dun tipo de arado de ferro que lle chamaron "granchón», nus sitios, e, noutros, «arico». Pois ben: hoxe noto que, ademáis desas palabras, son de uso corrente na lengua labrega de Abadín (Lugo) «esgranchonar» e "esgranchonadura», «aricar» e «aricadura», as segundas formas nas comarcas da serra e as primeiras, xa máis pra o sul ${ }^{10}$. Na lengua literaria recordo estes dous casos. Penso que foi Correa Calderón, [quen] sacóu a relucir a palabra «ronsel». Hoxe apenas hai poeta gallego que non teña derivado «ronselar». De «señardá», unha palabra que usóu por primeira vez Leiras Pulpeiro, saliron «señardade» e «señardoso». ¿E pra qué vamos a citar máis casos?

O vocabulario dunha lengua viva está formado por un número máis ou menos grande de palabras, legadas polos antepasados, que non sempre facemos nosas, e por un número moito maior de posíbeles creaciós que pode entender doado todo aquél que conoza as primeiras. Este conxunto, de gran riqueza de por sí, non representa aínda o vocabulario total. Cada palabra non representa un solo sinificado. Os dicionarios encárganse de señalar os máis que poden. Pero as posibilidades de sinificación dunha palabra nunca se poden precisar por enteiro. Basta unha nova construción pra que unha palabra tradicional gane unha nova sinificación, sin deixar por eso de ser ben entendida. A palabra "pértego» ven definida pouco máis ou menos en $\mathrm{M}$. Valladares como unha das partes do malle ${ }^{11}$, a máis grosa e pesada, que sirve pra desgraer o pan. Esta palabra entra nestas frases: "pértego vai e pértego ven, acabouse a airada» que eu acabo de facer, e nestas outras «anda ós pértegos todo o día, sin facer nada», «leva un bon

\footnotetext{
${ }^{10}$ [Vid. infra n. 16].

11 [Marcial Valladares NuÑEZ, Diccionario gallego-castellano (Santiago 1884) 362 s. v. malle: «V. manle»; 366 s.v. manle: «MANLE. Azote para desgranar las mieses; especie de instrumento de madera, compuesto de dos piezas, llamadas mangueira y pértego: aquella, para coger con las dos manos y como un metro sesenta y tres centímetros de largo; este, para azotar la miés y como ochenta y cuatro centímentros, también de largo, pero más grueso que la mangueira»].
} 
pértego na máu», que oín moitas veces. Todas elas son ben claras pra quen lle seña familiar a palabra pértego. En ningunha delas, con todo, mantén a primeira sinificación.

Vistas así as cousas, resulta que o vocabulario gallego é unha tulla inmensa de palabras vellas e novas, de bos ditos e bocaladas, de palabras comús e de palabras enrevesadas, de palabras secas coma paus do forno e de palabras espresivas, cheas de humor e agarimo. Resulta ademáis que nada é máis cambiante que o ir e vir deste vocabulario, que se está sempre á facer e refacer, que é sempre o mismo e sempre é distinto. Pero, por enriba de todas estas cuestiós, a que os amantes da lengua de Galicia senten, sobre todo, é a do orixe deste vocabulario. De onde veu cada palabra. En que intre pasóu á nosa lengua. Outro problema relacionado con éste, anque non é tan vivamente sentido, é o dos cambios de sinificación que vimos que esperimentan as palabras. Saber cándo, cómo e por qué unha palabra cambia de sinificación é conocer o máis interesante da súa propia vida. Duas cencias naceron pra dar resposta a estas dúas cuestiós: a etimoloxía e a semántica.

A etimoloxía, que ten por patrón a S. Isidoro, ríxese hoxe por leises moito máis estreitas que as isidorianas. Inventar etimoloxías foi unha pasión que dominóu e domina á grandes espíritos. E, con todo eso, penso que pra ningún traballo lingüístico se precisa estar máis equipado de saberes, método e tenacidá que os que a etimoloxía require.

Pra sentar con certeza o orixe dunha palabra gallega non abonda encontrar outra ó bon tuntún que se lle pareza. A fonética esixe, en primeiro lugar, que os seus fonemas se correspondan un por un cos do étimo proposto. Pero ademáis requírese que seña clara a relación de sinificado e que as circunstancias históricas, xeográficas e sociales non se opoñan. Sobre a lengua gallega traballan hoxe escelentes etimoloxistas, que deixamos citados. É moito, con todo, o que hai que facer. Menos se ten feito aínda no que se refire á historia das palabras e ós seus cambios semánticos. Teñamos fe en que todo veña á ben algún día.

Antes de comenzar a historia do vocabulario gallego, queremos aínda distinguir nel dúas categorías, a das palabras que teñen unha sinificación propia (sustantivos, adxetivos, verbos e adverbios) e a das que non sirven pra espresar outra cousa que as relaciós en que as primeiras aparecen na frase (determinantes, indeterminantes, preposiciós e conxunciós). No primeiro grupo cabe 
distinguir os sustantivos comús e os propios, e, dentro destes, os de lugar e de persona.

A vida destas distintas categorías de palabras non é realmente a misma. Mentras que unhas se están renovando tódolos días, como logo veremos, outras traspasan os límites da duración da propia lengua.

\section{O FONDO ORIXINARIO DO VOCABULARIO GALLEGO}

O fondo orixinario do gallego está formado polo latín vulgar de Galicia, do que desconocemos todo canto se aparta da koiné do Baixo Imperio. Era esta koiné unha lengua de vocabulario espresivo, chea de imaxes; unha verdadeira fraga de derivados populares, en trance de grandes trasformaciós, debido ás vellas e novas penetraciós célticas e xermánicas, e, sobre todo, ó mundo estraño do Cristianismo.

Na súa maior parte, os caracteres desta lengua son comús nun comenzo á toda a Romanía. Bota fora os arcaísmos dos poetas como aequor, crus, os, tellus, unda, si ben se conserva este derradeiro en Galicia por cultismo eclesiástico.

E cercaron-mi as ondas, que grandes son.

Palabras ben vivas na lengua literaria do fin do Imperio, como pulcher, potare, lanio, e ager, deixan de correr na fala de cada día, coa escepción tamén pra Galicia da que vai ó cabo. A loita dos sinónimos alius-alter, magnus-grandis, omnis-totus decídese a favor das formas fonéticamente máis cheas, "autro», "grande», «todo», sin que falte a representación dos primeiros na lengua dos clercs, «al», «maño», «omne».

As palabras xa curtas de seu, como aes, os, ut, ve, desaparecen e outras que non se sinten moi fortes cálzanse de derivados. Auris, orella, genu, xonllo, vetus, vello, tórnanse en auricla, genuclu e vetulu. Adiuvare, axudar, refaise sobre o participio en adiutare e canere, cantar, en cantare. Os verbos irregulares tenden a correxir as súas anomalías (posse, poder, conforme a pot re), ou a declararse vencidos diante un sinónimo regular (ferre, levar, diante, levare, velle, querer, diante quaerere). 
Giacomo Devoto ${ }^{12}$ estudia por tramos as anovaciós do latín imperial. Según él, pode decirse que, hasta o fin do siglo III, o latín de cada día desenvolveuse con caracteres costantes, levados ós últimos confís do Imperio polas correntes do comercio, da adeministración e da cultura, que eran aínda uniformes nun ambente que tamén o era. Nada máis que neste período se pode espricar a difusión de algús feitos lingüísticos que se van conocendo pola comparación das lenguas romances e que, fora deste período, non se poderían dar máis que nas comarcas de orixe. Este é o caso de algunhas palabras erráticas como lama que, salidas dos máis escuros currunchos, esténdense por toda a Romanía. A única esplicación é que, coa tradición dunha lengua literaria e os modelos escolares, iban e viñan tamen polas calzadas do Imperio as memorias dos funcionarios civís, militares, xurídicos e das finanzas. E nesas memorias iban e viñan as anovaciós, os substratos sin tradución, que chegaban a Roma e de alí se estendían por todo o Imperio, sin que na lengua literaria se refrexase o menor cambio.

Non foi sobre todo un vocabulario novo o que se estendéu e se fixo común polas vías do Imperio. Foron máis ben formas e costruciós alleas á tradición literaria de Roma, máis libres e espresivas, as que se estenderon polas calzadas. Formas gallegas como «diante» e «dentro», coincidentes coas da máis estrema Romanía, presupoñen asociaciós de palabras, introducidas no siglo III precisamente, e difundidas por todo o Imperio.

Nada máis lonxe da verdá que considerar como fenómenos particulares dunha lengua os feitos que se produciron fora da súa verdadeira historia. Romana e ben romana, debida á unidá adeministrativa do Imperio, ós relatos de curatores e iuridici e ó ir e vir polas calzadas dos soldados, mercadores e colonos, portadores do latín das ergástulas, da Suburra, dos máis lonxanos campamentos e das súas terras de Etruria, do Lacio ou da Campania, é a tendencia xeneral á reforzar os casos con preposiciós, que foi adiante en todas partes, menos en Rumanía; a de prescindir das desinencias compricadas e a de facer uso do perfecto composto con preferencia ó simple ( habeo factum frente a feci).

Este perfecto composto non era desconocido na tradición literaria, pero limitábase á certas formas de valor espresivo especial. Ó estenderse polo Imperio

${ }^{12}$ Giacomo Devoto, Storia della lingua di Roma (Bologna, 1934) páx. 81. 
perdéu aquel carácter estilístico e alternóu en todas partes co perfecto simple inda que na Península Ibérica, e, sobre todo, en Galicia, non o avantaxase.

Outras anovaciós do siglo III son as alteraciós do sistema pronominal, sobre todo nos demostrativos; o trunfo do comparativo perifrástico (magis miser) frente ó sufixal (miserior) e a desaparición da pasiva desinencial, que xa viña amenazada de vello pola analoxía das formas de perfecto.

As vías romanas multiplicaron a confusión que houbo sempre entre as formas pasivas de presente e as dos verbos deponentes, hasta o punto de que tódolos verbos podían ser deponentes. Esta situación foi favorábele pra ir á simplificación, que se levóu á cabo prescindindo das desinencias pasivas, que xa nada decían. Foi un proceso lento, pero universal de toda a Romanía.

Aparte moitos cambios fonéticos que se tiñan cumprido neste tempo (caída do $i$ en hiato e de certas postónicas internas, confusión de $b$ e $v$ ) aparecen nesta data gran número de neoloxismos. É deste tempo o sufixo -ELLU, que tantas formas deu ó gallego, e o verbal grecizante -IZARE que tamén tivo aquí fertuna. Moi de notar tamén son os moitos barbarismos que o latín deste tempo estendéu, xermanismos sobre todo, que non fixeron máis que arrequentar os que xa tiñan entrado no latín desde o siglo I a. C. ${ }^{13}$. Destes xermanismos foron avante os que prenderon na fala dos servos da gleba, entre os que figuraban moitos da Xermania, que foron medrando día a día. De aquí saíron palabras de cuciña, como «fogueira», «rustrir», «brasa», «sopas», «frasco», «tapón», e palabras de campamento como «guerra», «berida», «helmo», «espora», «trégola», «trotar», etc.

O siglo IV cambia o sino dos feitos. A reforma de Diocleciano, coa súa compricación adeministrativa, tivo por resultado a aparición de moitos centros que absorberon a corrente que, anos atrás, afluía e refluía, de Roma hasta os confís do Imperio, coma dun corazón. Ás tres cabezas da triarquía, xúntanse as das provincias coas dos seus concellos, que pasan a ser 87 de 47 que eran.

Dentro destas comarcas, forman tamén as súas cabezas tribus e civitates que xa viñan de vello, pero que agora se cerran en argolas máis estreitas. As anovaciós de cada lugar xa non se perden nin estenden na universalidá do Imperio, desaparecendo ou sumándose ó poderoso organismo da koiné.

\footnotetext{
${ }^{13}$ BRUECH, Der Einfluss der Germanischen Sprachen auf das Vulgarlatein (Heidelberg, 1913) páx. 86 ss.
} 
Inzán e rebustécense nos pequenos recantos das diócesis e prefeturas, despóis que éstas pasan á capitales e Roma perde o seu poder centralizador e universalizador. Tréveris, Milán e Sirmio pasan á ser tres mundos independentes e Roma queda fora das grandes vías imperiales. O latín vulgar do siglo IV pasa a ser latín dialectal. As irradiaciós unificadoras xa non chegan ós estremos do Imperio. Unha mostra é a persistencia do $-s$ final no campo occidental de Tréveris ( nenos», «les enfants») e a súa caída na área de Roma («I promessi sposi»), onda xa era moi vella esta tendencia que hasta entón se fora contendo.

Hasta que punto chegóu a dialectalización pódese ver por esto. O latín da Península hispánica, inda que procedendo de diversas camadas, que se correspondían cos diversos períodos da colonización, garda unha uniformidá grande, que ninguén pode negar. Hai, con todo, diferencias que sólo por este acantonamento do siglo IV se esplican. A España do Sul, ligada á Roma desde vello e que mantivo esta unión, garda formas da lengua común que Galicia recibe de outra fonte. A pesar dos concilia das cabezas de diócesis, que, na súa medida mantiñan a misma acción niveladora da antiga Roma, o latín das comarcas foise arredando máis cada día, debido ós substratos nativos que volvían á tona e ós superstratos dos bárbaros, que iban entrando nas distintas comarcas, cada vez en maior número.

Neste intre, poñamos o ano 313, unha nova forza renovadora irrumpe poderosa sobre o ruínoso edificio da lengua de Roma. O Cristianismo trasformóu de tal maneira o latín que as lenguas romances reparten o seu vocabulario entre dúas fontes, unha pagana e cristiana a outra. Deste punto de vista o gallego é sobre todo latín cristiano. Mgr. J. Schrijnen estudia profundamente este problema ${ }^{14}$, que se presenta compricado polo feito de presentar unha cara literaria retardataria e outra popular de lengua falada, que sigue as correntes dialectalizantes.

A primeira penetración do cristianismo na latinidá leva consigo a creación de todo un sistema de tecnicismos relacionados coa doutrina e o ritual da nova relixión. Estes tecnicismos foron feitos con palabras latinas que podían manter o seu sinificado (deus), con arcaísmos resellados cunha nova sinificación (lavacrum) e con palabras gregas ou hebreas, lixeiramente latinizadas (genhenna, pascha). Todas perturbaron por igual o latín falado e o escrito.

${ }^{14}$ Mgr. SCHrijnen, Carakteristik des Altchristlichen Latein (Nimegue 1932). 
A lengua dos apoloxistas cristianos, inda que calcada nas tradiciós literarias da Roma pagana, cárgase dunha nova vida. Os novos tecnicismos proliferan en derivados que refán a lengua hasta os molos. Este latín literario cristiano pasará, coa caída do Imperio, á ser a única forza retardataria do dialectalismo crecente, que comenzará despóis de mediado o siglo XIV. Pero como se separaba cada día máis a lengua falada da escrita, o seu poder unificador non era máis que relativo. A súa forza de contención limitase ó tecnicismo dogmático e litúrxico, inda que en comarcas de vida monástica tan intensa como Galicia puidera ter unha forza rectora meirande.

Fíxose sentir tamén o seu poder moderador ó traveso das pelerinaxes á Roma e Xerusalén. As numerosas pelerinaxes do siglo IV, nas que figuran tantos gallegos, proban a esistencia aínda dun falar común, sentido como latino e universal.

Fora de ahí, a gran revolución cristiana favorecéu, á larga, a dialectalización. O verdadeiro momento da dialectalización do latín vulgar de Galicia é o que nos describe o probe Obispo de Chaves, e no que o país pasóu polo meirande estado de turbación que se pode imaxinar.

Houbo reasentamentos en todo o país e unha fonda penetración nos máis apartados lugares, que antes non se conocera. Desaparecen os centros escollidos de onde saíran Prisciliano, Bachiario e os Avitos, verdadeiros castros cristianos do latín Imperial. Lévase á cabo, por razós políticas, unha desmembración máis ou menos efectiva da comunidá hispánica, pola que Galicia se une máis ben ás Galias. Desde o 417 hasta o 469, en que a historia dos Suevos se perde, líbranse loitas sin fin contra os hispano-romanos do país e contra os visigodos das fronteiras, coas alteraciós lingüísticas que esto supón. A chegada de S. Martín de Braga, considerado no seu tempo como verdadeiro Apóstol de Galicia, ó lado de S. Pedro e S. Paulo, corona todos estes feitos. El é o primeiro que chega ou abre o camiño pra que outros cheguen coas súas fundaciós monásticas ó verdadeiro corazón de Galicia. A organización diocesana non parece que tivera saído dos arredores dos centros urbanos, o que quere decir das comunidás hispano-cristianas. As aldeas gallegas seguían sendo paganas, como sabemos polo De correctione rusticorum. O momento do latín dialectal de Galicia é éste, en que o hispano-romanismo se afundíu como forza rectora política e foi desbancado como forza relixiosa. Pero nel habían de actuar aínda as inmigraciós visigóticas e mozárabes pra rematar na lengua que temos hoxe e que non comenza realmente hasta a desfeita do reino visigodo. 


\section{RENOVACIÓN DO VOCABULARIO}

\section{IMPORTACIÓN}

\section{1. [Como nacen as palabras]}

Partindo do estudio do fondo primitivo dunha lengua, a súa historia é a dos seus neoloxismos, dos seus arcaísmos e dos seus cambios de sinificación. O fondo primitivo do gallego era tan reducido como podemos supoñer nunha sociedá tan estremadamente bárbara como era a nosa do siglo IX, á que lle viña moi froxo o latín pra espresar as máis das cousas e ideas de que tiñan noticia. As cousas cambiaron axiña. Desde o siglo X hasta o XIII a vida de Galicia foi un medrar costante, no que a lengua deu o seu primeiro estirón. Neste período foi no que o gallego recibíu un maior número de neoloxismos, e no que, polo tanto, houbo tamén un maior número de palabras vencidas.

Unha palabra é obsoleta ou arcaica cando lle sale un retoño sinónimo que fai as súas veces na boca dos novos ou na de aqueles que pretenden falar millor. O día que este sinónimo novo chega á estenderse, o vello vai sin remedio pra a coba escura das palabras sin uso, coma un carto vello, inda que non sin a esperanza dunha resurreución.

A base vital do neoloxismo é a necesidá de dar cada día nome á unha cousa nova e á unha nova idea. Contra esta razón non valen as críticas dos puristas que quixeran unha lengua firme nas formas que se lles antoxan máis belas, como si se tratara dun fermoso mármore. Esto, que é verdá pra tódalas lenguas, éo moito máis pra o gallego. Unha lengua de longa tradición literaria conta cunha riqueza lésica grande pra opoñerse á invasión esterna do neoloxismo. O gallego non pode facer eso co seu reducido vocabulario labrego e mariñeiro. Unha nova idea pode espresarse nunha lengua rica cos recursos propios moitas veces, quedando reducido o neoloxismo a unha novedá semántica. É o recurso do portugués que lle deu o nome de «chovedoiro» á ducha. Pero aparte que esto leva á mesturar 
palabras do fondo vulgar con outras do falar escollido, marchando así á contrapelo do xenio da lengua, ten a dificultá de entullar de sinificados distintos, e contrapostos ás veces, unha misma palabra, si non se quere recurrir á rodeos tan estremosos como o de chamar «caneta de tinta permanente» á unha estilográfica.

Os tecnicismos de toda cras foron sempre a primeira fonte do neoloxismo e hoxe máis que nunca. Ós sabios e ós técnicos, que son do noso tempo, fanlles falla palabras libres de todo outro sinificado, que casen ben e con xusteza coa súa idea. Os produtos da industria e do comercio precisan nomes rechamantes que os introduzan no mercado. Tódalas épocas sentiron esta necesidá, pero ningunha tanto como a nosa, industrial, comercial e centífica por escelencia.

En Galicia temos aínda outra razón pra espricar o neoloxismo. Refírome ó feito de que nos chegan tódalas novedás por intermedio da lengua oficial, considerada como espello de ben decir e inculcada en tódolos centros de cultura: na escola, no instituto, na universidá, nas prácticas da vida civil, militar e relixiosa, todas elas fontes de neoloxismos. O gallego, deste xeito, non sólo se vai enchendo de neoloxismos, senón de palabras castellanas, que non é a misma cousa. Non é esto unha cousa nova. J. Vendryes cita o caso do Urdú literario e a lengua dos tzíganos armenios, en que o vocabulario é totalmente estraño á lengua, sin que ésta perda a súa individualidá. Estes neoloxismos son na súa maioría cultismos, helenismos ou latinismos, patrimoño común de toda a Romanía.

O neoloxismo non se reduce á pedir prestadas palabras ós veciños ou a desenterrar os vellos tesouros clásicos. As lenguas renóvanse moitas veces desde dentro. Cando á palabra «labrar», traballar unha terra, ou un madeiro, se lle deu a sinificacíon de «bordar» (vestida de pano labrado) creóuse un neoloxismo, chamado un cambio semántico. Hai neoloxismo tamén cando de «pousar»e «fol» creamos "pousafoles», que pasa á sinificar unha pedra que sobresale á porta do muíño e na que se pousa o saco pra abrir máis doado a porta. Este procedimento de renovación chámase composición. A mellor reserva con que unha lengua conta pra renovarse de seu é a derivación. A este procedimento debe o gallego unha boa parte do seu vocabulario actual e nel garda o xerme do seu potencial renovador. Son moitos os sufixos que morreron, pero son moitos tamén os que gardan toda a súa vitalidá.

Non tódolos períodos son por un igual renovadores. O sino que os distingue é o cultivo literario da lengua. Según esto, foi un periodo renovador o que vai 
do XII ó XV no que florece a poesía dos Cancioneiros e a prosa dá os seus primeiros pasos, e outro, o tempo que vai dos comenzos do XIX hasta hoxe. Esto, con todo, non é máis que á medias válido pra o gallego, lengua falada antes que nada, na que os periodos de actividá renovadora se deben medir máis ben polos de trasformación social, política e, sobre todo, económica, que sufríu o país. $\mathrm{O}$ vocabulario da cociña dun labrador de hoxe estóu seguro que non presenta menos neoloxismos que a páxina dun escritor moderno.

Podemos distinguir dúas clases de palabras: "palabras madres», que están á cabeza de cada familia de conceptos, e "palabras fillas», que se ordenan ó redor das primeiras. «Terra» é unha palabra madre. «Terreo», «terrón», «terraxe», «terraxín», «aterrar», son palabras fillas. Dígase o mismo de «verde» frente a «verdoso», «verdegado», «verducido», «verdegar», «verdecer», «reverdecer», «verdiño» e «verdecente».

Pra crear palabras madres as lenguas non contan con moitos recursos. A onomatopeia, que lles deu nomes ó cuco, ó pazpallar, á rula, ó chasco e ó pimpín, non é un método regular. $\mathrm{O}$ de dar ás cousas o nome do seu inventor ou fabricante ten un uso reducido e dá nomes pouco espresivos. É por todas estas razós que os métodos máis usados foron e son os de importación, composición e renovación semántica, cando se trata de palabras madres, e o de derivación, cando se trata de palabras fillas.

\section{Palabras importadas}

A importación de palabras é resultado da importación de cousas e ideas entre xentes de falas distintas. Ós galleguismos que introducen no castellano as nosas vieiras e nécoras, responde o castellano cun número moito maior de palabras propias.

Algunhas destas importaciós non tardan en desfigurarse na lengua do país. A «trilladora» convírtese en «máquina de mallar» e a «aventadora» en «máquina de limpar». Pero a cousa normal é que se manteña o nome orixinario, ben pola semellanza das dúas lenguas, ben pola pobreza de recursos do gallego. 
Neste último caso, hai que distinguir o neoloxismo importado sin concencia da súa naturaleza e o sentido como de fora. A maior parte dos que entran no gallego son do primeiro tipo. Cando un mecánico fala de «poleas», «tornillos», «tuercas», "palancas», «bielas» e «tubos de escape» non se lle ocurre pensar que está falando en castellano. O feito de manter a fonética castellana de "tuerca», «biela» e «tornillo» provén do seu bilingüismo que lle impide reaccionar no sentido da lengua propia. Pero si nesta hai as mismas palabras, non duda en sustituíla e aparecen entón as «buxías», "pistós», «chaves», «caldeiras» e demáis palabras que teñan correspondencia na lengua común.

De todas maneiras, son tántolos neoloxismos importados que os escritores dos nosos tempos, ó revés dos do siglo pasado, se plantean o problema da súa asimilación, e resólveo cada un á súa maneira. Tratan us de apelar á fonética histórica. «Tuerca», «biela» e «tornillo» convertiríanse en «torca», «bela» e «tornelo» que repunan a todo gallego-parlante por estar fora da concencia lingüística común. Outros botan mau do portugués -«tú que non podes, lévame ás costas»-, co que can nunha servidume moito meirande.

A solución xusta é quizaves a que nos dá a xente dos burgos e aldeas, cun pouco máis de coidado que se poña. Basta con rechazar solamente aqueles fonemas ou grupos fónicos que non teñamos en gallego hoxe. O sufixo -ERO, por chocar co de -EIRO, tamén vivo, ademáis do fonema de $j$ e os diptongos $i e, u e$, son quizaves os que non queipa ademitir.

A tradición histórica apoia de algúnha maneira esta solución. Nos escritos da Edá Media abundan castellanismos sin galleguizar, como «menor», «mezclar», «reina», «salir»e «viuela».

\section{Fontes de importación}

Son móitalas palabras que o gallego importóu das lenguas máis apartadas, si ben algunhas delas lle chegaron, pola súa situación xeográfica e política, ó traveso do castellano. Entre o siglo X e o XV puido importalas directamente, dadas as súas relaciós con Francia, Italia e os países árabes, e dada, sobre todo, a influencia das pelerinaxes á Santiago.

Están señalados estes préstamos na lengua literaria dos Cancioneiros, pero aparte destes, que non se incorporaron á lengua común, senón en moi pequena 
medida, hai outros máis ou menos directos. Os frades do Císter puideran traer a palabra grangia, "granxa», que relegóu á simple locativo "graña», de granea. Galicismos da Edá Media son, ademáis dos literarios, «señer», «greu», «cousir», «conorto», «nulo», «nula», "poncela», «leu», que non se incorporaron ó gallego, outras palabras aínda vivas como «dulzor», «rúa», «bercio» e «fustalla». O traveso do castellano chegaron outras como «xefe», "xardín», «forxa», "paxe», «batalla», «golpe», «navio», «verxel», «xoya», «madama», etc.

Os neoloxismos árabes puideron entrar tamén directamente, coas cousas que desinaban. Son en gran parte nomes técnicos, que se perderon coas industrias e novedás que un día representaron. Dos que quedan, corresponden á lengua común «arrabaldo», «alcacer», «aldaba», «achaque», «albízara» e outras, que nos deberon chegar por Castilla. A lista máis ou menos compreta de arabismos figura na "Gramática histórica» de García de Diego. Estes arabismos gallegos, en xeneral, teñen a misma forma que os castellanos, pero non sempre concordan os sinificados. De «aduana» derivou «aduanar» e «aduanado», que vale tanto como azacaneado e azacanear. "Gabela» sinifica feixe pequeno de calquer cousa. «Azougado», de «azougue», ten o valor de lívido, «azacán», o de desaseado e "cáfila», o de grupo de xente de mal vivir.

Os neoloxismos de outras lenguas modernas entraron todos ó traveso da lengua oficial. Non daremos máis que un pequeno mostrario.

Son de orixe provenzal e moi antigas, «albergue», «banqueta», «barrica; italianas, «acostarse» e «acostamento» (na Crónica Troyana) «acaparar», «alarma»; alemás, «potasa», «cin», «vermú»; inglesas, «franela», «ron», «sesión», «verediuto», «voto», «humor»; holandesas, «amarrar», «quilla», «leste», "garlopa» e «berbiriquí»; escandinavas, «equipar», «babor» e «estribor».

Palabras tan comús hoxe como "coche» e "pistola», chegaron hasta nosoutros desde Checoslovaquia. A primeira, ó traveso do húngaro, do alemán, do francés e do castellano.

Sendo moitos os neoloxismos que o gallego pedíu prestados ás lenguas modernas, moitos máis recibíu do latín culto. Os primeiros testos gallegos, particularmente os en prosa, están cheos deles; pero inda a lengua vulgar, nacida ó pe de unha laura monástica como tiveron moi poucos países, presenta moitos latinismos, apenas tratados fonéticamente, como "credo», "paternoster», "palio», «acerra», e expresiós como «en verbo» (con toda verdá), «por encenas» (por festas), «iverbuxido!» (polo Verbo unxido). 
Os tradutores de documentos da Edá Media tiñan un gran sentido do gallego que os escritores de hoxe temos perdido, debido á que moitas leises fonéticas e formas sufixales entón vivas, están hoxe caducadas. Palabras como «terreáes», «creschao», «cabidoo», «angeo», «conteente» son en algunha parte cultismos tratados fonéticamente ó xeito da lengua común polos tradutores. Outros escapaban á estas leises, como «ordino», «divinidade», "precioso», «spíritu», "proverbio», "púrpura», «querelarse», «sacrificio», «soteleza».

A palabra aeclesia, sometida ás dúas forzas contrarias do cultismo eclesiástico e das tendencias populares non arribóu nunca a ningunha que se impuñese con forza, polo que se poden presentar as variantes de «Egleja», «Egreja», «Igreia», «Eirexa» e «Iglesia».

Fora dos períodos literarios, foi escasa a influencia do cultismo, si non é na lengua relixiosa, que non chegóu nunca á forma vulgar.

Os escritores do XIX, coa escepción de Pondal, limitáronse á recibir o cultismo do castellano. Este ten algún que outro, como «turma», que parecen vir das súas lecturas dos clasicos latinos. Todos eles en xeneral, e señaladamente a gloriosa triada de Curros, Rosalía e Pondal, empedran os seus versos de cultismos románticos, debido ás vibraciós estéticas que neles sentían.

Entre os escritores de hoxe hai poucos que non señan partidarios do cultismo, si ben se perden algús nunha penosa labor de restauración histórica, coa pretensión infantil de acubillar a nobreza da antiga lengua de Roma. O resultado son párrafos como o que sigue: «A aición corrosiva e a acumiación de detritus criando novos broques, produxeron a alteranza». Está todo él formado por cultismos, si prescindimos dos artículos, das partículas e de dúas palabras. Pero o autor empénase en tornalo vulgar, pra un vulgo minoritario de eruditos que conoza catro leises de fonética, a non ser que escriba pra os señores Condes de Betanzos ou Monterrey.

Os progresos das cencias e industrias, unha técnica cada día máis esixente en tódolos campos, a tendencia á abstracción da nova literatura, que busca os fondos escuros dos meirandes refinamentos sicolóxicos, e o afán de aparentar tamén, manteñen o cultismo na primeira liña.

Polo que se refire á súa adaptación ó gallego, xa dixemos que nun comenzo era total moitas veces, debido á vixencia das leises fonéticas ou, cando menos, á unha concencia moi viva dos feitos fonéticos en latín e en gallego. O escriba do 
mosteiro sabía moi ben qué grupos consonánticos daban $c h, l l$, ou $x$; qué consonantes intervocálicas caían. Todo esto sin pensar, pola mecánica escolar adeprendida, que debía basarse precisamente sobre este problema.

Hoxe non podemos chegar á tanto e debemos contentarnos con galleguizar os sufixos, e éstes, lixeiramente. A lengua falada sigue nesto moi de cerca ó castellano. O sufixo -ATIONE que noutros tempos deu -AZÓN, dá hoxe -ACIÓN, como en castellano (oración, gobernación). O sufixo -UMINEM, en cambio, prefire a umbre a forma en -UME (legume, volume), o mismo que o sufixo en -AMINE (enxame, madeirame). Os en -ABILEM, -EBILEM, -IBILEM oscilan entre a forma castellana e as de -ÁBELE, -ÉBELE, -ÍBELE (amábele, volúbele) pola resistencia do gallego ós grupos de oclusiva máis líquida.

Os demáis sufixos siguen a misma tendencia. O sufixo -ATEM, tende a dar -Á, por influxo castellano (humildá), inda que a lengua literaria tende a manter -ADE, -ATUN, -ADO, sin que falten os en -ATO (aparato); os en -OSUM e -OREM, -OSO e -OR, OS en -ANTIA e -ENTIA rompen tamén coa tradición medieval e dan -ANCIA e -ENCIA (circunstancia, clemencia, frente ao San Cremenço dos Cancioneiros); -ARIUM e -ANEUM non gardan tampouco lembranza das formas tradicionales, e dan -ARIO e -ÁNEO (diario, pedáneo ou pedanio).

Aparte os sufixos, as terminaciós en -UM e -IUM, dan -O e -IO (sufixo, remedio); e os verbos entran normalmente nas tres conxugaciós, según a norma tradicional.

Non faltan en gallego os cultismos gregos, inda que limitados á lengua primitiva e medieval, por un lado, e ós tecnicismos modernos, por outro, debido á falta en Galicia de verdadeiro renacemento humanista. Son helenismos antigos, chegados polo fondo primitivo da lengua, palabras como «castaña», «carta», "corda», «ostra», "cara», «tío» e outras moitas, particularmente de plantas medicinales, como «asento», «cecimbre», «xeixebre», «cascamelo», «prixel», «codeso». Resultado da influencia da lengua cristiana, son os helenismos, «abade», "crego», «eirexa», «mosteiro», "paraíso», «crisma», «bispo», "parroquia» e outros moitos.

Tamén son antigos "cada», «bodega», que ten o mesmo orixe que «botica», «caixa», «saco», «bolsa» e «orfo». En todas elas labróu a fonética vulgar profundamente, polo que apenas poden entrar no grupo de cultismos. Os cultismos gregos propiamente tales aparecen moito máis tarde, ó traveso do castellano como resultado dos préstamos das diversas cencias. Son semicultismos gregos 
palabras como «selorgía», «solyrgiao» e «crysolitos», que atopamos na Crónica Troyana. Os primeiros helenismos propiamente ditos aparecen nos escritores do siglo XIX e pouco a pouco na lengua vilega que comenzóu á usar as novas espresiós centíficas (larinxe, farinxe, síntoma, tráquea, píloro, teléfono, telégrafo, etc.). Hoxe está invadida de gran número deles hasta na máis remota aldea debido á que a lengua centífica, en tódolos seus aspectos de laboratorio, droguería e farmacia, está formada por enteiro de palabras gregas ou greco-latinas.

\section{COMPOSICIÓN}

Hai dous tipos de composición. Consiste o principal en xuntar dúas palabras de sinificación independente que, pouco a pouco, perden esta independencia e dan unha nova palabra e unha nova sinificación. O estudio destes fenómenos é importante na historia dunha lengua porque, como a xuntura se fai según os principios sintácticos de cada tempo, resultan por eso doados de datar. As combinaciós capitales que se poden dar son as de nomes e verbos, adxetivos e nomes, verbos e nomes, nomes e adxetivos, nomes con nomes, adxetivos con adxetivos e verbos con verbos.

\section{Compostos de nomes e verbos e verbos con verbos}

Esta combinación é típicamente latina. Desde a súa nacencia, parecen perder nestes compostos a independencia os componentes. Abundan no Teatro de Plauto e menos no latín vulgar que tantos arcaísmos arrastraba. O gallego herdóu «samesuga» de sammisuca (sanguisuca) e quizaves "carricanta». Nos documentos do siglo IX e X aparece Aqua-cadit, que pode ser unha falsa etimoloxía latinizada. De calquer xeito, nin «aqua cadit» nin «carricanta» se axustan ó tipo de «samesuga», no que o elemento sustantivo é complemento. Este tipo perdeuse realmente no romance, pois que non atopamos máis que a combinación de substantivo suxeto con verbo, e inda ésta, nos contados casos que vimos.

A combinación típicamente romance é a de verbo e sustantivo, que tamén é de dous tipos. O primeiro, co verbo en indicativo e sustantivo complemento. Abunda en topónimos como "Catabois», «Catasol», "Catasueiro», «Pousafoles», 
"Mallaferro». No Códex Calixtinus (I, 345) chámase Lavamentula ó río Lavacolla. Ben se ve que é unha latinización dun nome interpretado por aprosimación, pero de calquer xeito supón o conocemento deste tipo de derivados.

Non se rexistra ningún destes compostos, que eu sepa, nos Cancioneiros nin na prosa medieval. Con todo eso deberon aparecer pronto os nomes compostos deste xeito pra desinar oficios e artefactos como «tiracordas», «correcás», «portapaz», «botafumeiro», «tirabalas».

Co tempo fixose un dos procedimentos de composición máis preferidos, ao menos pra nomes de tipo humorístico como «lambefoulas», «apertarrabos», «calcarrabos», «lambetorcidas», «sacarroña» e «zarrabuqueiros». «Petapouco» debe entrar tamén neste grupo.

Outro tipo é o de verbo en imperativo con vocativo, que puidéramos ver en algús locativos como «Mexaboi», e «Cantarrá». Forma algús sustantivos como «mexacán» e «tentemozo», pero non ten a vitalidá do tipo anterior. Polo caracter imperativo do verbo podemos citar aquí «fervellasberzas», que polo complemento corresponde a outro tipo e aínda citaremos outros: «vaicheboa», «funganacinza» e "vichelocrego», que non entran ben en ningún dos grupos.

A frase analítica «vaiche boa» sinifica: «¿qué se lle vai facer?, así é a vida». Pero en espresiós coma ésta: "puxo a saya á estilo de vaicheboa», é un composto que alude á unha vila imaxinaria e ten o valor de descoidado. «Puxo a saya de calquer xeito».

«Funganacinza» alude ós gatos enfermos e fraques que se arremuínan ó redor do lume e sinifica unha persoa sin ánimos, encollida, porca e miserable. «Víchelocrego» ten orixe nunha onomatopeia. Trata de imitar o canto da ouropéndola e dá nome a este páxaro.

Un tipo especial de compostos con verbos fórmano certas frases esclamativas que, por desgastes fonéticos, viñeron a convertirse en interxeuciós. Son deste tipo «canté» (canto é), «cantiá» e «descantiá» (canto y ha, des canto y ha), «madia leva» (mao día leva), «malia» (mal y ha) e algunhas outras.

Sin chegar a formar compostos, algús verbos repetidos en algunha das súas formas teñen valor de sustantivos ou adverbios. $\mathrm{Na}$ frase: «hai que ter un ten con ten», «tencontén» é un verdadeiro composto que vale tanto como «tento», "ponderación», "prudencia». Nesta outra: «os botós da chaqueta están vou non vou» 
non é tan clara a composición, e sinifica a espresión «están pra caer». Si se trata de personas sinifica "estar indeciso».

A repetición pode cambiar de forma verbal, como en "facendo que fai». Neste caso a perífrasis (non nos atrevemos a chamarlle composición) ten sinificación verbal e sinifica "cubrindo as aparencias».

Outras veces repítese a forma verbal, pero con distinto verbo. Os que se usan pra estes casos son «ir e vir», "tirar e virar» en frases como "pasóuselle o día en ir e vir», "andivo indo e vindo", "pasei todo o día tira vira hasta que veu a noite». A espresión «ir e vir» ten o valor de "dun lado pra outro». E a de "tira vira», sempre en indicativo, a de «seguidamente», "sin parar». "Tumba que dalle», "dalle que dalle», "zumba que zumba», "fala que fala», "tece que tece», "berra que berra», "conta que conta» e ainda outras son espresiós usadas con valor adverbial de modo cos verbos «estar» ou «andar». Todas estas espresios están en trance de ser compostos, limada que foi a súa sinificación, raíz da súa independencia.

\section{Composición de nomes e adxetivos}

Os compostos de sustantivo e adxetivo levaban no latín vulgar o adxetivo diante. $\mathrm{O}$ adxetivo posposto parece que mantiña a súa independencia. Ó vir o romanceamento invirtíuse o orde. O feito de nos dar o Codex Calistino un Sicca Molina non é argumento en contra, xa que os documentos con que contamos nos presentan os topónimos compostos todos co segundo elemento adxetivo (Portum lutosum, Lamamala), coa esceución cando a hai dos compostos de «bon» e «malo». O mismo que lles pasaba en latín, estes compostos non perden de todo a súa independencia nos nomes comús, á non ser que medien grandes cambios fonéticos, como acontece en «hhoramá!», «veladoce», «imaodía!». Outros como «toxo femo», "gato fero», «millo paínzo», si ben é que se refiren á cousas ben individualizadas, manteñen a independencia dos seus componentes. Trátase de xugadas linguísticas, xunguidas sempre ó mismo cancil, sin por eso fundirse nunha sola palabra. Outros compostos deste tipo son os escarnios «maríamol», "lácardada», máis ou menos fundidos na fala popular. Do tipo arcaico temos «bizcoito», "mediodía», "segunda», "tercia» e "cuarta feira», que datan, ó parecer, do tempo de S. Martín de Dumio, e os compostos de «bon» e «malo», «bon varón» (á ollo de bombarón), «abofé», xa «boafé», «maodía». 
A composición máis común é a de dous sustantivos, xustapostos ou en réximen. A primeira forma parece ser a máis antiga, sobre todo nos topónimos, e hoxe é moi usada pra desinar cousas que teñen dous oficios (Cama-cuna, café-bar).

Os compostos por subordinación poden ser arcaicos, feitos sobre a declinación latina. Neste caso, os máis vellos presentan a forma de determinante máis determinado («ourive», de auri faber, «cabrifollo» de capri folium) e os máis novos ó revés («filigrés» ou «fiigrés» de filiu aeclesiae). Fora dos topónimos son moi raros os dous tipos de compostos, e sobre todo os segundos. Dos primeiros podemos aínda citar «maimendro», de meli-dendron, e «lorbaga», de lauri baca.

Os compostos modernos de subordinación preposicional son abundantes, pero os seus elementos resisten a fundirse nunha sola espresión. Son móitolos nomes de plantas e istrumentos de oficio que teñen esta forma composta (lengua de ovella, pe de páxaro, pau de ferro, trade das zocas). Unha lengua coma a nosa, pobre en tecnicismos, ten necesidá de formar estes compostos pra moitas cousas (arco da vella, lastra da porta, campo da feira, caixa das ánimas, can de palleiro, etc.).

Os compostos de dous adxetivos son poucos e recentes, importados do castellano na maioría (verdescuro, azulceleste). «Lusco e fusco» parece unha forma sustantivada.

Con «ben» e «mal» e participios de presente ou de pasado téñense feito compostos sustantivos desde antigo, como «benadante» e «malfadado», e coa particula «como» e un sustantivo fanse compostos adxetivos. Antonio Noriega Varela recolle moitas destas formaciós no seu libro "Como falan os brañegos», entre as que escollemos «coma o demo» (moi malo), «coma a neve» (moi blanco), «coma un buxo» (moi sano).

Quizaves puidera parecer que me escedo dando como compostas moitas das espresiós que levo enumeradas. Eu penso que non. Un grupo calquera de palabras que evoque un concepto ou unha cousa sola, faise por esto mismo un composto, ó decir de Brunot. Cando decimos que unha persona se aborrece por un «dácame acó esas pallas», vemos ben que «dácame acó esas pallas» se refire a unha sola cousa, como cando decimos «nun abrir e zarrar de ollos», "cun pé aquí e outro aló», e outras polo estilo.

Reducido e todo, o gallego conta cun sistema de composición desde os seus comenzos hasta o día de hoxe. 


\section{DERIVACIÓN}

Imos á estudiar xuntos os procedimentos que ten o gallego, como outras lenguas, pra modificar a sinificación dunha palabra pola adición ó comenzo ou ó cabo dun prefixo ou sufixo. Teñen moito de común os dous procedimentos, pero sepáranos tamén moitas cousas. Prefixos e sufixos proceden de palabras, máis ou menos gastadas. Pero os prefixos teñen vida independente máis ou menos tempo e os sufixos non. O prefixo perde a súa fertilidá cando non se ten concencia do seu valor, e ó sufixo non lle ocurre esto. Os prefixos, pra ser fértiles, teñen que quedar un pouco despresos da palabra (retoñar, re-facer, re-moer), e os sufixos fúndense estreitamente con ela. Todo esto, con todo, é cuestión de máis ou menos.

Da riqueza que supoñen estes dous procedimentos de neoloxismo podemos darnos conta con recordar algús derivados. De «palla» hai «pallar», "palleiro, palleira, pallada, palloza, pallugada, palleta. De «poñer», «apoñer», «compoñer», «descompoñer», «espoñer», «impoñer», «repoñer», «supoñer», «traspoñer».

Estes dous exemplos son, por eso, engañosos. Moitos dos prefixos e sufixos con que outrora se contaba están hoxe mortos en gallego, como noutras lenguas.

\subsection{Prefixación}

Dos dous procedimentos de renovación que vimos estudiando, o máis pobre, con moito, é o de prefixación. Un gran número de prefixos desapareceron do uso. Xa no remate do latín vulgar desaparecera o sufixo A- e AB- confundidos con AD-; E-, ganado por EX-; DE-, por DIS-; CUM-, que había tido tantos derivados no latín vulgar, desparece como prefixo moi cedo, inda que deixando derivados. Quedan con toda a súa forza proliferante AD-, IN-, EX-, DIS-, PER-, PRAE-, PRO-, SUB- e RE-, e habilítanse novas preposiciós e adverbios como prefixos, tales como INTER-, CONTRA-, MINUS-, BENE-, MALE- e TRANS.

A Edá Media sírvese do que se chama composición parasintética, e nosoutros chamaremos doble derivación, por medio de prefixo e sufixo, como «desagradecer», «desaconsellar», «derrancadamente», «desperecer», e aínda con doble prefixo, como «desassemellado», «desaguisar». 
Ao pasar ó gallego sufriron unha nova baixa os sufixos que acabamos de numerar. Quedan á cabeza AD-, DIS-, EX-, RE-, SUB- e TRANS-, inda que tódolos demáis se aclimataron tamén en moitas palabras que viñeron no fondo primitivo ou que impuxo o latín da Iglesia. IN- aparece en palabras antigas como «incenso», «enfiar», «enfornar», «inxirir», e outras, todas elas de uso normal. Diante vocal, perdeuse, ó caer o N-. In-amicu, deu primeiro «iimigo», e, como esta forma non tiña ningún valor expresivo, acabóu por desaparecer. Na lengua de hoxe non ten moita vitalidá. Sólo se percibe o seu valor de movemento nos verbos de comenzo de acción, como «entrar», «encetar», de onde pasa á outros verbos non compostos, por analoxía (emprincipiar, encomenzar). Como cultismo revive ó compás do castellano.

PER- non parece que tivera nunca máis vitalidá que a que lle daban os semicultismos eclesiásticos, onde abundaban os seus derivados. Úsase este prefixo nos Cancioneiros pra facer espresiós superlativas á maneira culta e nos verbos «perfacer», «perfíar», «perjurar» e outros. Os escritores modernos introducen do portugués "percorrer» e "pervagar», non sei si con algún fundamento en localismos que puidera haber. $\mathrm{Na}$ lengua común aparece con algunha frecuencia en palabras do fondo orixinario como "perdurar», "perguntar», "pernoitar». A proba de que non se ten concencia do seu valor é que se confunde moitas veces con PRE- (prefeuto, preguntar), sufixo éste que conta en gallego con poucos derivados e éstes, orixinarios, como lle pasa a PRO-: "pretender», "presumir», "predicar»; "proveito», "procisión», "provir». Ambos prefixos aparecen en palabras do fondo latino-cristiano sobre todo, e de ambos á dous se ten perdido o sentido do seu valor.

INTER-, CONTRA-, MINUS-, MALE-, BENE-, como queira que teñen valor independente, non se pode decir que señan prefixos mortos, pero contan con moi poucos derivados e éstes cultos ou semicultos. De INTER- figuran algús arcaísmos na Crónica Troyana (entrepelar, entretallar) ademáis de algús derivados na lengua común (entrecoller, entreter). O xeneral é que seña refeito o prefixo (intervir, interpoñer).

De CONTRA- hai tamén poucos derivados (contradecir, contrapear, contrapoñer, contrafacer, contraporta, contraforte), pero vese ben a súa vitalidá. 
MINUS-, MALE- e BENE-, fora dos derivados orixinarios, non se sinte que proliferasen. Algunhas formas históricas como «meoscabar» foron refeitas en «menoscabar»e «menoscabo».

Do resto dos prefixos, señan ou non prolíficos, é moi vivo o seu valor de istrumentos de derivación.

AD- é o prefixo que amenaza con suplantar a todos. Absorbéu a sinificación propia de EX-, fundido hoxe semánticamente con DIS- en «arrincar» (lat. eradicare), «alongar», (lat. elongare); reforzóu moitos primitivos (arroubar, aseñar) e entra como un fonema protético en moitas palabras da lengua vulgar. Este prefixo espresa moitas veces unha idea de reforzo, que era totalmente allea á partícula latina.

EX- e DIS- (ES- e DES- en gallego) encerran unha idea de desorden, destrución e movimento. Os seus derivados son moitos desde os tempos máis antigos hasta hoxe. RE-, como en todo tempo, é moi prolífico. Ten a ventaxa sobre todos de poder apoñerse á tódalas categorías de sinificación natural. Os seus valores de iteración e reforzo son sentidos con claridá polo que fala, calquera que seña o seu grado de cultura. Os derivados de RE- non hai dicionario que os poida archivar, porque nacen tódolos días.

En comparación con él, os prefixos SUB- e TRANS- son moi pobres. SUB- (SUou SO- en gallego) nin conserva hoxe na lengua vulgar poder prolífico algún, nin se garda a menor idea do seu valor. Falamos del sólo pola súa brilante historia no gallego. Aparte de ter dado un bon número de derivados á lengua común (sofrer, sufrir, sospirar, suspirar, soterrar) deu algús de topónimos, estrados por todo o país, e ademáis parece que vive como preposición en algunhas comarcas, desmentindo a opinión de Nyrop, que fai depender a vida dos prefixos da vida das partículas. SUB- e RE- son unha boa proba. RE-, que nunca tivo vida como partícula en gallego, é o prefixo máis vivo, e SUB-, que inda a ten, ó menos na espresión «su brazo», debaixo do brazo, perdéu toda a sua forza de prefixo.

TRANS- mantén vivo o seu valor de prefixo. A forma vulgar TRANS- mantense frente á erudita TRANS, que entra en moitos cultismos de uso común, como «transporte», «transfusión», «tránsito». Garda o sinificado orixinario, e, o mismo que SUB-, entra na formación de moitos topónimos. 


\section{Renovación de prefixos}

Cando un prefixo envellece, ben porque se funde coa palabra, ben porque se perde o seu valor, a lengua tende á renovalo. Esto pode ser de dúas maneiras: ou introducindo un prefixo novo, tomado das lenguas clásicas, ou refacendo o vello. Este movimento de renovación é recente, e débese á convivencia dos prefixos tradicionales cos que introduce día a día a lengua culta, no noso caso, o castellano oficial.

Aparte RE- caso estremo de vitalidá, renovóuse BI- e BIS- en moitas palabras que penetran polo castellano: en «bisabó», frente a «trasabó», «bilateral», «bicicleta»; CO- de CUM-, en "compatriota», «convite», «convidada», «colega», «coasociado». ESTRA-, desconocido na lengua tradicional, é hoxe moi vivo pra espresar superioridá (estrafino, estraordinario). PRO- úsase no seu valor clásico de «á favor de» en espresiós como "pro-seminario», "pro-infancia», "pro-hospital», inda que a lengua vulgar reacciona confundindoo coa espresión "pra o", e correxindo as concordancias (pr'ó seminario, pr'á infancia, pra hospitales). ENTRE- de INTER-, está renovado case totalmente (interpelar, interrumpir, interliñar frente á entre-liñas). «Interdiuto» úsao Curros Enríquez. PRE- suma ás vellas unha idea nova de enceto en "preestablecer», "preelección», "prevotación». ANTE- e POSTteñen unha vida moi activa na fala de tódolos días, alternando as formas vulgares coas técnicas (antepenúltimo, antepasado, antediluviano; postumo, posterior, posdata), seguindo nesto unha longa tradición. IN- renóvase co valor da negación (improdutivo, inservíbele) e SUPER- (SOBRE-) co de escelente («superfino», que alterna con «estrafino», «supervisado», «supernumerario», «superposto»). ULTRA-, que entróu fai tempo en ultramarino, vai á elas con ESTRA- e SUPER-, usándose tamén con algús adxetivos.

Estes últimos son resultados da propaganda do comercio. Non tardan en gastarse. Cámbianse us por outros e están sempre en movimento. Depende de que non son realmente espresivos. A espresividá dun prefixo nótase ben pola pronuncia recalcada que lle damos e pola claridá que mantén diante a palabra. Cando ésta falta é que pouco sinifica. 


\section{Prefixos cultos}

A lengua centífica, que tende de día á día á facerse máis universal, e que, polo mesmo, interesa de igual maneira á tódalas lenguas, usa modernamente moitos prefixos gregos e latinos, ou que se toman por tales, anque en orixen non o señan. En gallego, onde non foran conocidos outros prefixos gregos que os de "Arcebispo», «arcediano» («arcediago» na Edá Media), «arcipreste», "Anticristo», «paralís», e non sei se algún máis, está hoxe invadida deles, como resultado da introdución dos produtos químicoindustriales. Palabras como «bisulfito», «bicarbonato», «hipertensión» e outras moitas veñen hoxe a sumarse ós tecnicismos escolares de «monosílaba», «bisílaba», "trisílaba»e "polisílaba», que hai algús anos que se conocían.

Todo este mundo novo, tan estraño ó gallego dos nosos antepasados, non é, con todo moi distinto do fermento lingüístico que Galicia conocéu noutras moitas ocasiós, particularmente no siglo V e no siglo VIII.

\subsection{Sufixación}

O recurso principal de que dispoñen as lenguas pra arrequentarse é o da derivación por sufixos. Son éstes palabras gastadas que perderon desde moi atrás toda independencia semántica. Sóldanse fortemente á raíz, pero mantendo unha sinificación adxetiva que dá color ás distintas categorías de pensamento. Debido á este procedimento, pódense aventurar tódolos días novas creaciós, inda que non sempre proliferen.

O fondo primitivo dos sufixos gallegos foi tomado ó latín vulgar e cristiano da colonización e da evanxelización. Deste fondo, moitos desapareceron, gastados pola fonética romance, e, pra o seu sitio, viñeron outros e outros, á medida que foron precisos. A invasión actual de cultismos busca no grego e no latín os recursos que require pra as formaciós que poidan portar as ideas xenerales da civilización dos nosos días.

A morte dos sufixos ven por desgaste da súa forma e do seu sinificado. Cando un sufixo non aporta un novo matiz ó tema nin sirve pra formar novas palabras é que está morto. En terras moi aproveitadas polo cultivo, como as que se estenden de Vigo a Porriño, ouservéi que a palabra «silva»é sinónimo de «silveira». 
Esto quer decir que o abó dos nosos sufixos comenza á ir pra vello, inda que manteña moita da súa forza e vitalidá.

Cando un fenómeno como éste se vai estendendo á moitos casos, como as cousas siguen vivindo e precisan nomes claros que as distingan, o sufixo vencido, ou se refai ou ven outro á sustituílo. Neste proceso dase unha verdadeira loita entre os sufixos, na que us acaban por desaparecer, mentras que outros se cargan de unha variedá grande de matices, herdados dos que foron caendo, que van ser, co tempo, o principio da súa disolución.

Vamos considerar aquí o estado da sufixación vulgar nos tempos que precederon ó seu romanceamento e logo notaremos as peculiaridades do gallego nos seus distintos momentos.

\section{Sufixación vulgar}

Desprendéuse o Latín Vulgar de gran parte do lésico clásico, pero conservóu a maior parte dos seus sufixos, de modo que se distingue máis polos que ganóu que polos que perdéu. O latín imperial arrequentara a lengua cun sinnúmero de derivados cheos de colorido e de espresión. Derivara verbos de verbos, de adverbios, de participios, de sustantivos e adxetivos. A novedá consistía na renovación e non tanto nos sufixos. Estes seguían sendo os da tradición: -ARE, -IARE, -IRE, -ICARE, -ITARE, -ISCERE, -ESCERE. Única particularidá: os dous derradeiros perdían o seu matiz incoativo, e -ITARE tamén perdía o seu de frecuentativo.

Realmente novos non hai máis que -IDSEIN, importado de Grecia, que deu -IDIARE. Estendido polos escritores cristianos, tivo moitos derivados cultos e vulgares. Os sufixos xermánicos -AN, -ON e -JAN arribaron a -ARE os dous primeiros e a -IRE, o final, co que se confundiron, esterilizándose. Realmente non estenderon a súa actividá fora dos verbos que os sostiñan, entre os que figuran «guiar», «roubar» e o histórico «gornir», ganado por «gornecer» moi axiña.

O gallego ten verbos feitos sobre -ARE (aterrar, gradar), -IARE (aguzar), -ICARE (salgar), -ESCERE (anoitecer). Tenos tamén en -ISCERE e -ITARE (cousir, gridar), pero trátase de verbos senlleiros, fora de uso case todos, que chegaron feitos ó gallego. Son sufixos mortos desde os comenzos da lengua. Pra sustituilos, aparecerán outros novos, dos que logo falaremos. 
Os sustantivos derivados do latín vulgar presentan un luxo de sufixos que desconocía o clásico e que algús remontan á 90 tipos. A maior parte pasóu ó gallego sin forza prolífica. Por de pronto tódos aqueles que non tiveran acento. A erosión fonética xa dera conta deles e reducíronse á terminaciós sinxelas, sin outro valor que o de marcar un acidente. Por este camiño desapareceron -UUS e -IUS en «antigo» e «fillo»; -CULUS en «ollo», etc. Reduciremos a nosa esposición á unha parte mínima da sufixación vulgar: á que pasóu con vida.

Perdido -CUlus, e aínda -ACUlus e -ICULUS, que del se desprenderan, tivo gran importancia -ELLUS, que da -ELO en gallego (cancelo, cadelo). Con el competíu de algunha maneira -ITTO / -ITTA, que aparece no siglo V, anque se cre prelatino e oscurecido todo ese tempo polo seu carácter vulgar. Parecen relacionarse con el -ATUS e -OTUS. Na loita de diminutivos entróu tamén o sufixo africano -ICCO/ICCA. Cada un polo seu lado unhas veces, encabalgados outras, ou de calquera maneira reforzados, deron os numerosos diminutivos vulgares. Aparte deles estaban:

-A, moi común na formación de femeninos,

-ALIA, de valor colectivo, aumentativo e despectivo,

-ALE, pra desinar prendas de vestir e istrumentos (brachiale, coxale, incensale)

-(A)MENTUM, -(A)NTIA, -TATE e -TIONEM, pra formar abstractos,

-ARE, -ANTE, -ARIA, -ARIU e -ATA, con moi distintos valores.

O sufixo -ÍA, con acentuación grega, fundiuse algunhas veces co sufixo -ARIU, como se ve en "bruxaría», «libraría».

-ITIA deu derivados abstractos como -ORE, e -ONE deunos aumentativos. Foron moi prolíficos

-TU, -TA, -SU, -SA, reforzados en -ATU, -ATA, etc., que procedían dos participios de pretérito en función de sustantivos (defensa, remissa) e daban sustantivos deverbativos. Pero -ATA non tardóu en formar derivados de nomes como annata, de onde provén o noso "anada».

-TOR da nomes de axente e, reforzado en -TORIUM, nomes de lugar e de istrumento (dormitorium, accubitorium). Nesta última sinificación loitóu con -CULUM, que era tamén istrumental. Os sufixos -TUDINE e -(U)MINE derivaban sustantivos de adxetivos, sempre de valor abstracto, polo que competían (fortitudine, moi común, e ferumine, xa en Petronio). 
-(T)URA e -(S)URA, que tiñan no latín clásico certo valor colectivo, fórono perdendo hasta convertirse en abstractos no vulgar (messura, pressura), vencidos neste aspecto por outros sufixos.

Entre os de prestado, ademáis do grego -ÍA, figuran:

-ISCUS, no que se confunden o grego -ISKOS e o xermánico -ISK. Este sufixo loitóu con -ICUS, que era fundamentalmente de carácter adxetivo.

-ALDUS e -ARDUS, non sempre xermánicos, cando o son, dan nomes propios, e noutro caso, despectivos (brutobardus (?), en S. Valerio).

Por fin, tiveron a súa importancia -INCUS e -INGUS e aínda -ANCUS, de orixe escuro, que entran na formación de algús nomes e adxetivos.

Tódolos demáis sufixos vulgares tiveron pouca ou ningunha proliferación en gallego.

\section{Sufixación adxetiva}

Entre os de máis vitalidá están:

-ABILIS e -IBILIS, sobre todo no latín cristiano.

-ACEUS/-ACIUS, -ICEUS/-ICIUS. Pra formar adxetivos de materia (cartaceus, setaceus) eran do falar labrego.

-ALIS e -ILIS formaban adxetivos de propiedá e alternaban neste oficio con -ANEUS/-ANIUS, -ANUS, -ONEUS/-ONIUS.

-ARIUS foi quizaves o máis importante, solo ou en combinación con -ICIUS (-ARICIUS).

Os participios de presente (-ANTEM, -ENTEM) e os de pretérito (-ATUS, -ITUS) deron moitos derivados (fatatus, timoratus)

Os xentilicios formáronse en gran parte sobre -ENSIS.

O sufixo decadente -EUS/-IUS reforzouse con -T-OR, -S-OR, dando -(T)ORIUS e -(S)ORIUS, que loitaron cos derivados en -BILIS.

-OSUS, rival de -IDUS (rabidus, non rabiosus no "Appendix Probi») trunfóu en toda a Romanía.

O reparto de oficios e sinificaciós deu lugar entre os derivados á curiosas loitas. O sufixo -ON, que era intensivo, pasóu á ser despectivo e diminutivo. Morto no seu valor -CULUS, loitan entre sí -ELLUS e -IOLUS. A punto de ser vencido o primeiro, refórzase en -ICELLUS. Frente ós dous prantouse aínda -ITTUS con máis ou menos fortuna. 
Outro caso de notar é o dos sufixos irmaos -ETUM/-ETA, especialidados pra desinar conxuntos de árbores. Foi -OSUS o primeiro en lles salir ó frente, pra sucumbir amos e dous diante -ALE e -ARIA.

\section{3. [Sufixación gallega]}

\section{Verbos}

De maneira semellante, fóronse desenvolvendo os feitos en gallego.

Tódolos sufixos que acabamos de notar pasaron ó novo romance, pero non mantiveron todos o seu valor semántico e a independencia necesaria pra seguir sendo elementos renovadores da lengua. Houbo un empobrecemento grande na lengua no intre da aparición do gallego. Moitas das series de derivados quedarían apenas con algún representante, e un sufixo que non se repite a miúdo é visto que non tarda en esterilizarse polo momento.

Dos sufixos verbales mantivo o seu poder renovador -ARE, que sigue servindo pra derivar tódolos verbos novos. Pode apoñerse á temas de tódalas categorías: á nomes prefixados ou non (ripar, sachar, regar, acamar, enlamar, ennovelar); á aumentativos e diminutivos (acantazar, pedichar). Nestes verbos pasa á acción o matiz aumentativo, diminutivo ou despectivo do tema, manténdose así a espresión afectiva do verbo, que o latín viña espresando polos infixos -ILLO- e -CO- (pipillo, conscribillo en Catulo, albico, fodico, citados por Meyer-Lübke).

Forma tamén derivados sobre temas adxetivos en «secar»e «baixar», sobre seco e baixo; sobre pronomes en «atuar», «aquestar» e «aquelar»; sobre adverbios en «acercar», «alongar», «tardar», e sobre preposiciós, en «encontrar», «atrasar».

Os temas preferidos son os dos participios. Os de participio de presente sirven pra formar verbos de acción instantánea ou que comenza, como «acalentar», «adormentar», «aferventar», «amolentar», que teñen normalmente sinónimos representando outro matiz (aquecer, adormecer, amolecer).

O número destes verbos vese moi aumentado polos derivados de temas en -EN, -TUM ou -ENTE, como "xuramentar» e «sementar».

Os derivados de participios de pretérito son os máis antigos, como que moitos proceden do fondo tradicional (axudar, cantar, embebedar, ousar). 
Ó revés do que pasóu cos de presente, que deron un sufixo gallego prolífico en -ENTAR, os de pretérito non deron ningún.

Os derivados sobre aumentativos, diminutivos e despectivos deron series máis ou menos longas en -ICAR, -ICHAR, -IPAR, -ISCAR, -UXAR, -OLAR e -ALLAR. Todos eles tiveron como precedente en latín a -ICARE, que atopamos morto en «amargar», "amosegar», de ad-morsicare, e a -IDIARE, que deu ó gallego -EXAR (rabexar, festexar), un dos sufixos máis vivos inda hoxe.

Os derivados deste último sufixo e os de -ICAR teñen un matiz iterativo fundamentalmente (pestenexar, lagrimexar, saltaricar, latricar), pero moi contaminado co resto destes sufixos, fondamente influídos pola sinificación do tema, pouco máis fan que reforzalo (pidichar, escurrichar, coucipar, petiscar, babuxar, cantarolar, parolar, baballar).

O sufixo -AR aparece en hiato, debido á caída dun -L- ou -N- intermedio, en moitas ocasiós, e, debido á eso, aparecen derivados en -EAR, -IAR, -OAR e -UAR, como podemos ver nos verbos «envear», «maquiar», «arpoar», «recuar». De todos eles cabe considerar o sufixo -EAR, independizado do seu primitivo orixe e que hoxe é un elemento fundamental de renovación. Aparte os derivados sobre nomes en -EO, -EA (bourear, amorear), pódeos formar sobre sustantivos de calquer terminación, prefixados ou non, como «secolear», "mourear», «espernear», e aínda sobre outros temas, como «chouchear» e «loulear», que son dous temas onomatopeicos alusivos á murmuración e ás cantarelas involuntarias con que se acompaña un traballo.

-ICARE non parece ter hoxe vida. En «amargar» e «resgar» é orixinario e está despoxado de toda vitalidá. Sobre temas sustantivos (aformigar, aconchegar, derregar) non representa ese sufixo, sinón o sufixo aposto a unha forma en -EGO, -EGA, como de bodega «embodegar», de barriga, «esbarrigar». Foi moi importante, con todo, este sufixo polo gran número de formas que del arrincan e que hoxe perduran, inda que estériles.

Outra cousa pasóu co sufixo incoativo -ESCERE de «anoitecer» e «amencer». Sobre dar ó gallego moitos dos seus derivados directos, estendeuse ós verbos en -IR, reforzándoos. Deste xeito desaparecéu «gornir» diante "gornecer» e «esparxir», diante «esparexer». Ademáis desto sigue sendo un dos sufixos máis vivos da nosa derivación verbal, sobre temas preferentemente adxetivos. As formaciós 
novas loitan ás veces coas en -EAR (marelear e amarelecer, branquear e enbranquecer). As en -EAR, neste caso, espresan simplemente o cumprirse da acción verbal, mentras que as en -ECER, o feito de cambiarse unha coalidá noutra, de tornarse branca ou marela unha cousa que o non era. «Louquear» é facer loucuras e «enlouquecer», tornarse louco.

Os en -IDIARE pasaron ó gallego en -EXAR con moitos dos seus derivados, coa súa forza neoloxizante e quizaves co seu matiz especial. Moitos dos seus derivados presentan formas paralelas en -EAR (espernear-espernexar, gotear-gotexar, patear-patexar, espolvorear-espolvorexar). As formas en -EXAR teñen normalmente un contido afectivo, pero, en algús casos, espresan renovación, conversión ou trasformación, que parece ser o sentido primitivo de -IDSEIN e -IDIARE.

Debido ós derivados nominales en -IZA, non é alleo á nosa lengua o sufixo verbal en -IZAR, irmao cultista de -EXAR. Deste xeito temos ó lado de verbos normales en -AR, feitos sobre sustantivos en -IZA (esperguizar, escachizar, alambizar) outros derivados de -IDSEIN, tomados en préstamo ó castellano, pero afeitos xa no gallego, como «martirizar» e «gargarizar», frente ós vellos «marteirar» e "gargolexar», dos que vive o derradeiro cun sentido xeneral dentro do que "gargarizar» ven a ser un tecnicismo.

Sobre os derivados sustantivos e adxetivos en -IÑO, como sobre os demáis, deriváronse moitos verbos en -AR. Destes derivados resultóu un sufixo en -IÑAR que non deixa de ter vitalidá, e do que se derivan verbos como «atoutiñar», «couciñar», «raspiñar», «dormiñar», que teñen un matiz afectivo sobre os orixinarios.

Os derivados sobre nomes en -ENZO/-ENZA foron moi poucos como poucos eran os sustantivos e nunca lograron desprender o sufixo -ENZAR pra facer novos derivados. De orixen culto como eran, restituiron por influxo da lengua de Castilla ou polo que fora o sufixo orixinario -ENTIA (-ENCIA en gallego) os sustantivos temas, e os verbos siguen polo seu camiño, inda que algús escritores se empeñen en buscar unha forma vulgar (axustizar, presenzar, sentenzar) que nin esiste nin ten tradición ningunha na historia da lengua. 


\section{Os nomes}

Dixemos que se perderan os sufixos átonos. Mantívose, por eso, o sufixo nominal -A na espresión do xénero (xato-xata, monxe-monxa, escuro-escura) e aínda con outros valores. Derivado dos vellos colectivos, conserva certo matiz aumentativo en nomes de cousas, onde o valor xenérico non se percibe. "Caldeira», «pucheira», «pota», «cancela», «portela», «carballa», «tixela» e outros, frente ós masculinos correspondentes, espresan todos cousas de maior tamaño. Un «tixelo» é unha sartén pequena e o mismo un «caldeiro», un "pucheiro». Si nos masculinos non se sinte o diminutivo, síntese o aumentativo nos femeninos.

-ALIA (-ALLA en gallego) mantén o sentido colectivo herdado en moitos derivados, como «fustalla», enseres dunha bodega, «borralla», montón de cinza, "presentalla», exvotos; pero os seus derivados andan moi mesturados cos de -ACULA que tiñan outros matices. Por esto se esprica que palabras como «fornalla», «nugalla», «zaramalla» teñan valor despectivo e que outras como «navalla», «vidalla»e "galla» non teñan ningún valor especial.

O sufixo en -ENDA, derivado do xerundivo neutro, consérvase estéril en algunhas palabras como «facenda», «moenda», «merenda».

-ALE sinificaba en latín vulgar prendas de vestir e istrumentos, como dixemos, e, sin deixar este valor (brial, avantal, caixal, varal), chegóu á sinificar conxuntos de árbores, frente á -EDO/-IDO e -OSO.

Con -ALE alterna, de vez en cando, -ARE (-AR en gallego), tanto en sustantivos como en adxetivos (pumar, lagar, anllar, lagar), pero sin ter unha actividá grande na historia da lengua.

Verdadeiramente activos son os en -(T)URA e -(S)URA, -ORE, -MENTUM, -(A)NTIA/-(E)NTIA, -TIONE e -TATE. Todos eles dan derivados abstractos.

O sufixo -(T)URA (-(D)URA) en gallego), presente en «mazadura», "premedura», «cosedura», foi en orixe un deverbativo de participio de pretérito. Atópanse tales derivados desde o siglo VIII. Máis tarde soldouse á algús adxetivos (planura, viridura) e dá moitos derivados como «bonitura», «brandura», «lentura», loitando ás veces co sufixo -(D)ORE (-(D)OR en gallego) que dá «quentor», "grandor», «altor», e aínda co sufixo gallego -ÉN, derivado do culto -EDINEM (dulcedinem), que aparece en algús derivados como «rouquén», "podrén», «roxén», «mourén», de que máis tarde falaremos. 
-(T)ORE especializárase en latín pra nomes de axente, pero tamén espresaba as resultas da acción, se ben non puido manter neste valor a competencia de -(T)URA en algunhas rexiós, según observa Cohn. En gallego mantívose o estado do latín vulgar e -(D)URA foi o derivado fundamental pra espresar resultas de acción, mentres que -(D)OR espresa nomes de axente ou de istrumento, inda que mantén moitos derivados con outros valores.

Os derivados en -(D)OR, polas súas relaciós cos en -(D)URA, tiñan tendencia a facerse femeninos e consérvana moitos e deles. En frase como "viñéronselle as colores á cara», "ten as dores», "non botóu fora máis que unhas verdores», "O prado está cheo de fedores altas», consérvase ben esta particularidá.

A forza destes derivados era tanta que atrouxeron ó seu grupo palabras de sufixo distinto, como «lebor» de leporem, «arbor» de arborem, unha e outra femeninas. Algús desenvolveron unha forma femenina en -ORA por analoxía cos de axente. E así, ó lado de «sabedor»-«sabedora», aparecéu "pastor»-«pastora»e «señor»-«señora» ó redor do siglo XV. Nos Cancioneiros, como se sabe, a forma destas palabras era «señor» e «pastor» pra os dous xéneros, como entón era normal. No gallego moderno os derivados máis vivos son os de axente e istrumento, pero, por influxo castellano, non aparece vencida a sinificación abstracta do sufixo en -(D)OR.

Os derivados de -(A)MENTUM son deverbativos. De orixe moi antigo, abundan no gallego literario da Edá Media (meresçemento, nasçemento, prometemento). Sigue hoxe vivo este sufixo e o seu valor, pero como dá palabras moi longas, que repunan ó equilibrio da lengua, prefírense outras formaciós, sobre todo nos verbos de tema en -AR. Así, en vez de «refregamento», dise refrega, por «acoramento», acoro, por «esquencemento», esquenzo, por «apertamento», aperto, por «adiantamento», adianto, facendo uso dos participios que, apoiados en nomes da cuarta declinación, deron xa no latín vulgar nomes abstractos como perda, tardada, fossado.

Os verbos en -ER e -IR son os que máis abundan en derivados en -MENTO.

Os derivados de -(A)NTIA e -(E)NTIA, que proceden da forma neutra do participio de presente, deron no gallego medieval -ANÇA e -ENÇA e tamén -ANZA e -ENZA, xa que nas grafías do XIII figuran «conucenzas» e "pertenças», correspondendo todas elas á misma pronuncia, que sería a de toda a península naquel intre, 
da que procede a que hoxe temos. Derivados tradicionales son «labranza», «tardanza», «folganza»; «tenza», «habenza», «mantenza», e aínda outros moitos en -ANZA e xa menos en -ENZA. Modernamente sigue en uso este sufixo, pero con caracter culto. Xa desde o siglo XV, a xuzgar polos documentos que temos, alternan as dúas formas (probancia, negromancia), e hoxe non é viva máis que a culta en palabras como «inorancia», «elegancia», "cencia», "pacencia» e «concencia».

Os derivados de -TATE e -TIONE son abundantes na literatura medieval (amizade, deidade, pedição, prijón, sagraçón, etc., nos Cancioneiros). O primeiro deriva sustantivos de temas adxetivos e o segundo, de verbos.

A forma histórica de -TATE é -DADE, viva no portugués e en algunha palabra solta do gallego que, sin ter este sufixo, teñen a misma fonética, como "cofrade», «frade», "grade», desparecéu do gallego moderno. Na lengua viva, que eu seipa, non se conoce outra que a forma -Á nos numerosos derivados deste sufixo (legalidá, libertá, humildá). Os escritores do XIX foi a que usaron normalmente, inda que non desconocesen a tradicional. Os modernos tenden a restituíla, quizaves con acerto. Debido ó paragoxismo natural do gallego, non resulta unha novedá estraña por demáis.

Con -TIONE pasa un fenómeno semellante. A forma tradicional é -ÇÓN, escrita de varias formas. Pero os derivados novos tornan á culta -CIÓN, nin máis nin menos que pasa en castellano. Consérvanse moitas formas históricas como «virazón», «eslabazón», pero non se sinte nelas o sufixo.

As observaciós que fixemos pra -TATE e -TIONE valen pra os sufixos -TUTE e -SIONE. O primeiro conta con derivados históricos en -UDE (virtude, soúde) que hoxe son en -Ú (actitú, rectitú), e o segundo trocóu os en -SON (procisón) en -SIÓN (pasión, prisión). Tamén aquí tenden os escritores actuales á manter as formas arcaicas.

Ligados con estes derivados abstractos están os en -ÍA, -ARIU/ARIA e -ATA. O primeiro foi introducido en toda a Romanía pola evanxelización. Era de orixe grego, pero non tardóu en ser ben acollido pra nomes abstractos, derivados de adxetivos (folía, vilanía, cortesía, retesía). Xa en latín vulgar se axugaba preferentemente á derivados en -ARIU, de onde provén un sufixo -ARÍA de gran vitalidá (libraría, granxaría). Por analoxía con este sufixo tenden á tomar tamén os deverbativos de axente en -TOR o sufixo -ÍA (feitoría, faladuría, sabeduría) e detrás deles os en -OR de calquer tipo que señan, inda os comparativos: 
«melloría», «moría». A forma medieval dá síntesis de -ARIU + -ÍA en -ARÍA (malataría, especiaría, cabalaría), pero modernamente, por disimilación nus casos e por analoxía noutros, téndese á forma -ERía ou -EIRÍA. A derradeira ven dos derivados en -EIRO. E así, mentras que de «rapaz» sal «rapacería», de "galiña» e «tesouro" salen "galiñeiría» e «tesoureiría», porque no medio se atravesan «galiñeiro» e «tesoureiro».

En canto á sinificación, fora dos abstractos orixinarios de calidá, os derivados en -ÍA teñen matiz colectivo (rapacería, galiñeiría) ou ben espresan resultados de acción (feitoría), lugar (cortaduría, alberguería) e aínda outros matices.

O sufixo -ARIU, que o mismo dá sustantivos que adxetivos, estaba en latín vulgar moi estendido pra formar nomes de oficios e profesiós. A súa primeira evolución foi en -AIRO/-AIRA, da que aínda quedan restos na zona oriental de Galicia en palabras como «rairo», «escairo», «aira», «ladrairo», «mazaira», nas que non se sinte ben o sufixo. A forma hoxe viva, e que se remonta ó siglo X, si nos atemos á documentos dese siglo, máis ou menos seguros desde un punto de vista lingüístico, é en -EIRO/-EIRA.

Ó lado dos nomes de oficio (zarrulleiro, ferreiro, cesteiro) e os de lugar (agulleiro, cazoleiro), que eran matices primitivos destes derivados, derivóu -EIRO/-EIRA nomes de istrumento, como «fungueiro», «rangueiro», «cancañeira», e de outros matices xa máis desviados dos primitivos, como nomes de árbores (pesegueiro, laranxeiro, castiñeiro, pereiro, bieiteiro); nomes colectivos (pataqueiro, galiñeiro, formigueiro, rimeiro), moi chegados ós locativos; nomes que indican sitios onde se dan e abundan certas plantas (silveira, fieira, fieiteira, xesteira, etc), todos coa terminación -A dos colectivos.

Os nomes de oficio e de lugar fórmanse sobre nomes sustantivos (ferreiro, forneiro); os de istrumento, sobre verbos (coadeiro, picadeiro, ripeiro) e relaciónanse co vello sufixo -TORIU que veremos logo.

Os nomes de árbores e os colectivos en xeral fórmanse sobre nomes tamén.

Os derivados en -ATA proveñen dos participios. Supónse que se sustantivase este sufixo pola elipsis dun sustantivo femenino de uso xeneral en algunhas espresiós dadas. Seña como queira, en latín vulgar apareceron axiña palabras como defensa, remissa, coas que se entroncan «debesa» e "remesa», e outras moitas palabras gallegas derivadas por este procedimento, como «desfeita», «chousa», «roza», ás que aludimos xa cando falamos do sufixo -MENTUM. 
Este tipo de sufixo non proliferóu máis que sobre a forma participial -ATA, a máis chea fonéticamente, pero nesta forma estendeuse á temas sustantivos, como annata (anada), derivada de annus.

A maioría dos derivados eran nomes abstractos, saídos de verbos, como «tardada», "chegada», «ollada»; os derivados de nomes, como «anada», eran colectivos. Tanto nun sentido como noutro, fillóu longamente este sufixo en gallego. Algús colectivos pasaron trópicamente a nomes de medida, como "cullerada», "garfelada», "cestada», e de aquí á aumentativos e diminutivos. O reparto de aumentativos e diminutivos ven regulado polo patrón medida. Si é pequeno, o derivado en -ADA é aumentativo, como "presada» de "presa», e si o primitivo é unha medida grande, o derivado é diminutivo, como "carrada» de carro, «valgada», de val.

Como noutros casos, o matiz aumentativo-diminutivo alterna con outro despectivo, que depende do tema e, sobre todo, do feito de ir este sufixo en -ADA aposto á despectivos orixinarios, como en «migaxada», «migallada», «fachucada». Por este camiño ten -ADA matiz despectivo en derivados como "aduanada», «antroidada», «bacorada», «bretemada», etc. No caso de «grasumada», «galdrumada» e outros o matíz despectivo quizaves arranque por sinonimia do vello sufixo en -UMINE (-UME en gallego) cos seus derivados "cheirume», "gafume», «fume», «estrume» e outros, todos eles cargados de repunancia, e sobre os que se derivan verbos tamén despectivos como «apadumar», «engrasumar».

Algunhas veces estes derivados poden pasar á locativos (arada, cavada, baixada, encrucillada), pero o sufixo non garda este matiz. O máis vivo hoxe e a sinificación de resultas da acción, pura ou compricada con matices afectivos, como en «orvallada», «nevada», «xeada», por un lado, e, por outro, «choromicada», «mixiricada».

Os derivados de nome sinifican unha acción en que o primitivo entra como suxeto (chuscada, parvada), ou como obxecto (martelada, fuciñada, pedrada, allada).

Hai outros nomes abstractos cos sufixos -IA (latino), -ITIA, -TUDINE e -MINE.

Según Lindsay, o primeiro destes sufixos, moi estendido logo no latín vulgar, servíu nun comenzo pra formar os femeninos dos participios de presente. De 
aquí pasóu á formar nomes abstractos, como pollentia e abundantia, do mismo xeito que o sufixo -A os formaba sobre os participios de pretérito e futuro (repul$s a$, textura), dos que xa falamos.

No latín vulgar estendeuse cos dous valores, pero o interesante foi que se independizóu dos vellos temas verbales e pasóu á formar derivados de nomes, como superbia, victoria, avia, neptia, etc. Pola súa estructura fonéticamente pobre non proliferóu en gallego, pero entra en moitas palabras, ben na forma culta (familia), ben na vulgar (feira), e noutras derivadas por analoxía en -IO (labio, estudio, concello).

Foi importante na historia da lengua o sufixo -ITIA/-ITIE, na derivación de abstractos de temas adxetivos. As formas históricas propias destes sufixos foron -EZA, -EÇE, alternadas con -IZA, -IÇE, por confusión dos sufixos orixinarios con -ICIU, -ICIA, presentes en "cortiza», «rabiza», «abellariza» e outros nomes. Os derivados en -EZA/-EÇE foron nun principio combatidos polos de -ANTIA, e nos primeiros escritos atopamos «firmança», "viltança» e non "firmeza» e «vileza». Formas en -IÇA aparecen desde os siglos XII (justiça, sandiçe), pero contadas. As en -EÇA abundan algo máis, pero en trovadores que non son gallegos, como Martín Moxa, que nos da «franqueza», «proeza», «escaseza», «avoleza», «maleza» e «soteleza», ou tardíos como Pedro Alfonso, Villasandino e Macías, que usan as formas «dereiteza», "pereza», «crueza», «sandeçe», «ledeçe» e algunhas máis.

No reparto -EZA/-IZA vencéu o primeiro, conforme á lei xeneral. Algún destes derivados refixéronse conforme ó patrón culto (xusticia), e os derivados de -ITIE, que modernamente dan -EZ en gallego, parecen ser máis vivos que os de -ITIA, como que alternan e desbancan as súas formas en casos como «vellez», «baixez», «robustez», «estrañez» e outros.

O mellor competidor dos sufixos anteriores en algunha comarca e -ÉN derivado do sufixo -EDINEM, presente en palabras como dulcedinem e putredinem, moi estendido no latín eclesiástico, xuntamente con -UDINEM.

A única forma histórica que conozo figura no trovador Xohan de Cangas, de mediados do XIII.

Con gran pesar fillou xi me gran tristén. 
Pero moito antes de conocela tiña recollido este sufixo na fala vulgar do N. de Lugo, en palabras como «bonitén», «gordén», «rouquén», «delgadén», etc. O poeta de Mondoñedo Leiras Pulpeiro usara a palabra "gordén» nun poema sobre a «Corrida do Galo», premiado en Vigo. Nesta zona de Lugo alterna con -URA, -OR e -EZA pra espresar ese tipo de abstractos que vimos estudiando.

En Portugal debe ser desconocido. J.J. Nunes, ó comentar a palabra «tristén» dos Cancioneiros, di que «deve ser palavra formada pelo autor».

En latín vulgar usouse moito tamén pra facer abstractos de adxetivos o sufixo -TUDiNE (-DUE en gallego) que ten algún representante na lengua escrita da Edá Media, como «firmidue», «semeldue», ganados na lengua vulgar por «firmança», «firmeza» e «semellanza». Tivo máis importancia o sufixo -UMINE, que alternaba con él, e deu en gallego -UME, como vemos en «lume», «fume» e «ferume».

Este sufixo, orixinariamente -MEN/-MINEM, servíu pra facer abstractos deverbativos en latín clásico como tegmen de tego e lumen de luceo. En latín vulgar aparecéu un xugo vocálico entre o tema verbal e este sufixo, que non sempre era a vocal temática (liquamen, sarcimen, acumen), e, de resultas, aparecéu unha serie de sufixos en -AMEN, -IMEN, -UMEN, con independencia pra facer derivados de nomes ou de verbos. No reparto destes sufixos, en Galicia parece ter vencido o derradeiro, sin que falten derivados dos dous primeiros. O lado de «vexame», «gravame» e «urdime», que parecen importados, temos «agume», "gafume», «cheirume», e moitos máis que son gallegos de corazón.

Dos en -IME é seguro tamén «molime». En «ferume» rexístrase a caída do -E, co que resulta «ferún», sentido como «farún» e sin verdadeiro valor de derivado. No «Tratado de Albeitaría» do sig. XIV, lese «magreduun», pero trátase dun derivado en -TUDINE, e parece unha forma alternante coa normal "magredúe», ambas e dúas semicultas.

Moitos son os derivados de sufixos diminutivos que non sempre manteñen a fasquía de tales. O antigo -CULUS atopámolo morto en «mollo», «malla» e outras palabras. Os que o viñeron á reforzar, -ACULUS e -ICULUS, tampouco manteñen o seu valor de diminutivos se non é no caso en que pasaran ó gallego os primitivos correspondentes, como en «ramo» e «ramallo», «pinga» e "pingallo», «corte» e «cortello», "ponte» e "pontella». Debe decirse o mismo de -UCULUS en "pollo», «restrollo», «ferrollo». 
O sufixo verdadeiramente diminutivo de orixe latino foi -ELO/-ELA derivados de -ELLU/-ELLA, e que atopamos en «bacelo», «bandelo», «vanelo», «cachelo», «campelo», «barbadela», «canela», «carabela», «causela». O reparto en -ELO ou -ELA depende dos primitivos. Os derivados manteñen o xénero que tiñan. Cando se trate de derivados de verbos ou non se cumpre o que deixamos dito, [ou] é que a terminación -A ten outros valores que deixamos espricados ó falar deste sufixo.

Con -ELLU/-ELLA está relacionado outro sufixo que atopamos en «mazola», «yxola» (aixola, eixola), «galiñola», «carolo», "pedrolo» e outros, alternando con outro en -OO/-OA procedente de -OLU/-OLA, presente en «filloa», «aboa», «abóo», «tirizóo», que hoxe escribimos «abó» e «tirizó».

A forma -OLU/-OLA é a corrente no latín vulgar (fasciola, brachiolis na «Mulomedicina») e tamén no latín romanceado do sig. XI e XII (feceirola, lenciolo, ecclesiola). Nun documento do ano 959 encontramos «uilla trauazollo», pero na onomástica topónima non encontramos máis que «Trabazón», polo que supoñemos que seña unha errata «trauazollo».

As formas «mazola» e «yxola», que aparecen en documentos do XV, e as da súa serie debemos derivalas dun -ULLUS raro, presente en algunha palabra moi antiga como «cepolla», pero que se estendéu moito en gallego, hasta dar cabo coas formas en -OO/-OA, representadas en gallego moderno escasamente por algús locativos e tecnicismos antigos, como «Pazóo», «Eiroa», «tirizó».

O sufixo máis característico do gallego, fora de Galicia ó menos, é o sufixo -IÑO. Procede do latino vulgar -INU, tanto na forma como no sinificado, pois orixinariamente «sinificaba propiedá e, de ahí, semellanza e pequenez», como di Grandgent ${ }^{15}$. Comenzóu sendo, polo tanto, un sufixo adxetivo en palabras como «veciño», de vicus, «oubiño/-a», de albus. Os seus temas podían ser, según esto, sustantivos ou adxetivos, e o seu valor adxetivo. Sería un error tomar por diminutivos palabras como «morriña», de murria, «nabiña», de nabo e os numerosos locativos en -IÑO ou -IÑA, como «Soutiño», «Valiño», «Vilariño», «Laxiña», etc., que proceden de adxetivos e non son máis que resultantes da perda do

\footnotetext{
15 [C. H. GRANDGENT, Introducción al Latín Vugar (Traducción del inglés, adicionada por el autor, corregida y aumentada con notas, prólogo y una antología por de Francisco de B. Moll) (Madrid 1928) 45].
} 
sustantivo correspondente. "Valiño» non é nunca un val pequeno, senón un monte que está cabo dun val, o monte do val. Asi «laxiña» sería «a casa da laxe», poño por caso; soutiño "o lugar do souto», etc.

O que debe terse en conta é que o sufixo -IÑO deixóu de ser vivo neste valor, e que, polo tanto, non cabe facer hoxe derivados dese tipo, como «diviño», «feliño», «ambariño», "coraliño».

Dos matices que hoxe conserva, o diminutivo, que xa tiña nas inscripciós imperiales -domnina, «doniña»- é o único que perciben as xentes que non penetran o xenio da lengua. Del nacen todos, pero sin confundirse con el. Sobre temas adxetivos, ten un matiz afectivo, que o mismo pode ser de intensidá que de atenuación. Nestes versos de Rosalía:
Mans de señora, mans fidalgueiras, teñen todiñas as costureiras

«todiñas» quere decir «todas en absoluto». O mismo valor superlativo ten nestas espresiós: «o primeiriño de todos», «erguinme cediño», «era noviña».

Outras veces tende á atenuar o primitivo. "Mareliño», «mouriño», «fraquiño», sinifican «un tanto, algo, bastante marelo, mouro, fraque».

Outras veces non ten ningún matiz particular, pero alude á forma primorosa, inxel, treviña, triste ou leda da cousa á que se refire o adxetivo. Así hai que interpretar o sufixo -IÑO en moitos casos como nestes versos de Rosalía:

Non me roubaran, traidores, ¡ai!, uns amores toliños, ¡ai!, uns toliños amores.

O sufixo -IÑO, aposto á temas sustantivos, dá diminutivos, como temos dito, pero con variados matices afectivos que, mellor que polo adxetivo pequeno, se esprican por outros adxetivos, como «doce», "pobre», «triste», «amado», etc.

O sufixo -ICCO/-ICCA atopámolo en contadas formas como «fachico», "repenico», «bilurico», «muxica», "penica», pero son moitas as súas variantes en -ECO 
(paxareco, valeco), en -OCO (bichoco, mazaroca), en -ACO (buraco) e en -UCO (abellaruco).

Este sufixo parece de orixe africano e puido orixinarse por unha pronuncia de neno dos antigos sufixos latinos en -ACULUS e -ICULUS (-AC'LUS e -IC'LUS) en nomes cariñosos e familiares.

Foi máis fecundo o sufixo -ITTO/-ITTA, sobre o que parecen descansar as formas gallegas en -ITO, -ITA, -ETO, -ETA, -ATO, -OTO, etc. Diminutivos deste tipo son «burata», «viaxata», «lebrato», «gambito», «abolito», "pingota». A serie máis longa é a dos derivados en -ETO/-ETA (carreto, galleta, lengoreta, cabalete, tabolete) e a dos en -ОTO/-OTA, que se distingue dos outros en formar os seus derivados sobre temas adxetivos preferentemente (baixote, pequenote, vellote), sin que falten os de temas sustantivos, como «cachote», «canigote», «rapazote».

Tanto os sufixos en -ICCO coma os en -ITTO foron de carácter popular. De ahí que non aparezan nas manifestaciós literarias dos primeiros tempos. Son moi vellos e aparecen en algunhas inscripciós da época imperial. Na onomástica gallega do sig. IX lense nomes con estes sufixos, como Atanitus (867), Senderica (871), Malucca (887) Heustoca (887). Moitos dos derivados de hoxe perderon o seu matiz orixinario, de modo que as formas vivas redúcense ás de -ETO/-ETA, -OTO/-OTA.

Moi interesante en gallego é a historia dos sufixos que serviron pra espresar locativos de árbores e plantas. O latín vulgar especializara pra estes derivados o sufixo -ETU, que temos hoxe vivo en «arboredo» e de onde procede outros moitos locativos de árbores, que sólo conocemos por certos topónimos, como «Salcedo», «Sabucedo», etc., que alternan cunha forma en -IDO presente en "Carballido», indicadora máis ben [de] accidentes do terreo e da paisaxe, como parece deducirse de "Lourido», "Verducido», «Tremoido», "Coído», «Pedrido», e que puidera relacionarse co sufixo -ITTU/-ITU.

E sin duda un dos locativos máis antigos deste tipo. A palabra robur que cedéu en Galicia diante «carballo», ó redor do sig. X, non conoce máis que este sufixo (Reboredo/Reboreda). No siglo IX atopamos loitando con el á -OSU e -ARIU (Codesosa, Castanaria no ano 887; Argiaria, Felgaria, Fraxenario, Genestario no ano 914).

O resultado desta loita vese nos locativos de certas árbores vellas no país que presentan a serie enteira das súas formas toponímicas. Así «Carballedo», 
«Carballido», «Carballoso», «Carballeira» e «Carballal»; «Castedo», «Castañedo», «Castañoso», «Castiñeira», "Castañeira» e «Castañal».

Estas formas foron as que contenderon, pero non sabemos á cencia certa en que orde. A primeira parece ter sido -EDO, vencida por -OSO e -EIRO, que vimos aparecer no sig. IX. -EIRO tiña nun comenzo un sinificado parecido á -EDO, colectivo, presente en «agulleiro», «formigueiro». Debéu ser, polo tanto, un mal enemigo pra -EDO. Non o era tanto -OSO, de carácter adxetivo, que espresaba a tendencia ou a propiedá de unha cousa á ter ou producir algo. «Folgoso» ou «Castañoso» valen tanto como terreos dados á botar fentos ou castaños. «Pedrosa», terreo de moitas pedras, e así «areosa», «laxosa», «xestoso», que inda non perderon o seu carácter adxetivo na lengua común, pero sí o de locativos propiamente tales. Esta indeterminación locativa de -OSO non era a mellor axuda pra vencer á -EIRO. De todas maneiras, estes dous sufixos arrimáronse por demáis e confundíronse, como vemos en "preguiceiro» e "preguizoso», "dadiveiro» e «dadivoso». Debido á esto aparecéu o sufixo locativo -AL/-AR no gallego moderno pra desinar os locativos de árbores. -EIRA é hoxe un locativo xeneral (pedreira, barreira, lameira, esterqueira) e pra os específicos de árbores trunfan, sin enemigos, os en -AL/-AR (pinal, pinar, alcolital). «Silveira» xa dixemos que se confunde con «silva» en algunha comarca e "piñeiro», desconocido na lengua viva como topónimo, con «pino» en casi todas partes.

Fora dos ditos, os sufixos máis importantes que quedan son os de istrumento e axente en -TORIU e -TORE respeutivamente.

-TORE, do que medio falamos, formaba parte dun grupo de sufixos deverbativos sobre participios de pretérito, no que entraban -SORE e -TRICE; pero quedóu solo en gallego como sufixo vivo. Nesta lengua alongóu o seu sinificado pra indicar a tendencia do axente ou a súa especial habilidá pra levar á cabo unha acción.

Así en «latricador», "cantador», «bailador», «falador», que están lonxe de ser nomes de oficio, como en castellano. O xeneral é que día nomes de oficio, con todo eso, e, tanto cun valor como con outro, sufre a competencia de -EIRO. «Gadañeiro» é un nome de axente e «cabaleiro» vale tanto como aficionado a montar á cabalo e tamén bon xinete.

O sufixo -TORIU servía no latín vulgar pra derivar sustantivos de verbos que indicaban lugar ou istrumento. Con estes dous valores pasóu ó gallego, como 
podemos ver en «firidoiro», "corredoira», "pasadoiro», por un lado, e «lavadoiro», «afungadoiro», «baloira», «devandoira»/«devadoira»/«dovadoira», por outro.

Pero este sufixo non tardóu en confundirse con -ARIU e apareceron entón as formas en -DEIRO, unhas veces con matiz locativo (fiadeiro, fregadeiro), outras, con valor instrumental (viradeira, tapadeira), ademáis dos valores propios.

De -ATICU (-ÁDEGO), -ASTRU (-ASTRO), -ISCU (-ISCO) e -INCUS (-ENCO) hai escasos representantes, como "pontádego», «belisco», «fillastro», «alamanisco» e «podenco» (poda pequena). O primeiro redúcese á Edá Media. -ASTRU perdéu a sinificación despectiva e os dous restantes son de moi pouca vitalidá. «Belisco» puidera ser unha derivación inversa de «beliscar»e «podenco», un diminutivo despectivo moi raro, creado quizaves humorísticamente sobre o seu homónimo castellano. Pra comprendelo, téñase en conta que tamén recibe o nome de «gateña» o mismo istrumento.

É máis importante que éstes -AXE de "ferraxe», «fogaxe», «friaxe». E un préstamo francés-provenzal moi antigo e ben afeito, por confundirse co que deu o sufixo -GINE en «ferraxe», de farragine, «imaxe», de imagine.

Entre os sufixos aumentativos e despectivos son de notar, ademáis dos señalados, os en -ÓN, -ÁN e -ANCHO.

-ONE, de onde ven -ÓN servíu primeiro pra individualizar as personas por un rasgo característico, como en Nasonem, Bibonem. De aquí á facerse despectivos non había máis que un paso, e, deste xeito, entraban na lengua como aumentativos e despectivos, e aínda como diminutivos en algunhas lenguas, debido á lei da afectividá que xoga moitas veces cos contrarios, como se pode ver no lenguaxe amoroso e maternal.

Entre os derivados gallegos mantén o seu valor aumentativo ou despectivo nas formaciós adxetivas (aforrón, rosmón) e nas sustantivas que manteñen o correspondente primitivo («caixón», de caixa, «navall-ón», de navalla). Noutros casos, pode moi ben non ter matiz algún (ferrón, aguillón, serrón) ou telo diminutivo, como no exempro derradeiro, si comparamos «serrón» con «serra». «Feirón» e «calexón» son diminutivos-despectivos de feira e calexa. «Leitón» sirve pra desinar toda clas de mamíferos de pouca edá. «Tallón» é un horteiro pequeno en algunhas comarcas.

O sufixo -ANCHO é moi antigo. A mediados do XIII figura como alcume do trovador Airas Corpancho. Parece estar composto de dous sufixos. Un o sufixo 
-ANCO de "panca», "labanco», emparentado con -INCO, de orixe prelatino, e outro, o sufixo -ULUS. Non son móitolos seus derivados (ferrancho, borrancho), pero moi vivos. Deles se derivan aínda outros como "ferranchin», «matanchín».

Tamén puidera espricarse este sufixo sobre a palabra "gancho» e quizaves fora o máis acertado, como imos ver por esta historia, coa que rematarémos a derivación sustantiva.

Haberá cousa de trinta anos que aparecéu no norte de Lugo un tipo de arado formado por catro ou cinco coitelas dispostas sobre un eixe, que se usaron e usan pra esfendelas terras despóis de recollelos frutos. Veu sustituír con ventaxa a grade, que non penetraba tan fondo e deixaba moito traballo pra o arado tradicional ou inda que seña pra a vertedeira.

Este arado nunha estensa comarca do concello de Abadín (Lugo) recibíu primeiro o nome de "gradón», polo oficio que viña desempeñar; pero non tardóu en chamarse "ganchón» pola feitura das coitelas, que semellaban ganchos. Alternaron algún tempo os dous nomes, pero ó fín remataron por encabalgarse e deron "granchón», unha palabra que xa entróu na lengua común da comarca e dispón da súa familia de derivados como calquer outra que conte centos de anos.

Non vive segura. Nunha das parroquias deste concello hai o costume de ir ás segas á Zamora. A labor que aquí se fai co "granchón» faise alí co «arico». E os paisanos da comarca de Baroncelle alternan o uso de «granchón» e «esgranchonar» co de «arico» e "aricar», que resultan verdadeiros misterios pra quen non conoza a pequena historia destas palabras ${ }^{16}$.

\section{Adxetivos}

Entre os sufixos adxetivos, figuran en primeiro lugar os dos participios de pretérito en -TO e -SO (estreito, raso, salpreso); pero os verdadeiramente prolíficos foron os reforzados en -ATUS, -ITUS e -UTUS, que lograron desprenderse dos temas verbales pra facer derivados sobre sustantivos e adxetivos. -ADO foi o primeiro en desprenderse e tamén é o que conta con máis derivados sobre sustantivos (anubado), adxetivos (amarelado), e sobre verbos (arrabeado).

${ }^{16}$ [Vid. supra n. 10]. 
En derivados denominativos é hoxe máis vivo -UDO que conta cunha longa serie ascendente (beizudo, bochudo, comenenciudo, cotomeludo, polainudo, etc.), coa particularidá de presentar un matiz despectivo en moitos e dos casos.

-IDO non conta máis que derivados deverbativos. Se conserva algún de outro tempo, como «colorido» e «descolorido»; «frolido», «lourido», «belido», parecen estraños, ou ben importaciós ou ben arcaísmos. Os deverbativos son abundantes e activos, como é natural, ó confundirse co participio.

Acerca de -UDO debemos notar a súa lunga pervivencia como participio dos verbos en -ER, sobre todo na lengua literaria (sabudo, metudo, ascondudo). Ao fin do sig. XII, a presión analóxica de -IDO, á que a tradición dos escritorios se rendéu, botóu fora do uso curialesco o participio en -UDO, que quizaves non correse xa na lengua viva.

O resultado das miñas pesquisas é éste: Hasta mediados do sig. XIII, é uniforme o uso de -UDO (recebudo, conoçudo, stabezudas, vençudo, metudo, sabudo, liuda, en documentos de 1250 a 1257). A partir desta data, comenzan as alternancias. Atopamos «metidas» nun documento de 1261; «sabido», nunha famosa cantiga de Payo Gómez Charino. Ao chegar o sig. XIV, pode decirse que hai un verdadeiro desconcerto, como nos demostra o vocabulario da Crónica Troyana, onde aparecen «atrevido» e «atrevudo», «ascondido» e "ascondudo», «confondido» e «confondudo», «sabido» e «sabudo».

Ben sei que a Crónica Troyana non é máis que unha tradución, e, polo tanto, un documento non seguro de todo. Pero danlle valor indubitado outros documentos do mismo tempo orixinales gallegos, nos que se atopa o mismo desconcerto, inda que con menos claridá. Obsérvase nestes documentos que os verbos que manteñen o participio en -UDO son os que entran sempre nas fórmulas curialescas, como «tiudo», «liudo». Os demáis prefiren a forma en -IDO, como «percebido» (1369), «descebido» (1371), «defendidas», «estabelescido» (1372).

A Crónica de Santa María de Iria, tradución directa do latín -a viinte et nove días do mes de março, ano Domini 1469- non presenta outros participios en -UDO que os da curialesca: «liudo», «tiudo» e «contiudo». Tódolos demáis veñen feitos en -IDO, entre deles, moitos dos familiares nos escritorios. Basten pra mostra «recebido», «ascondido», "perdido», «respondido», «rompido», «vencido» e «avido». 
Esto fainos supoñer que os participios en -UDO eran, había moito tempo, un problema ortográfico máis que outra cousa.

Destes participios non queda en gallego outro rastro que «mudo» ou «mundo». «Miúdo» é un adxetivo, como tamén o é «mudo», sendo «moído» o participio, polo que ningún dos dous son esceución. García de Diego di que tamén queda «tiúdo», cousa que non puiden verificar. De quedar, non terá valor de participio, que é o que salva da analoxía ós derivados nominales deste participio.

Inda que a espricación que damos nos parece válida, a persistencia deses derivados na forma orixinaria, xunto co feito de presentar matices característicos, fainos pensar si o sufixo -UTUS de onde proveñen será ou non o participial.

E xa un caso raro que este sufixo seña moito máis fecundo que os en ATUS e -ITUS pra derivados sobre nomes e adxetivos, e, sobre todo, pra derivados deverbativos. Pensamos por eso que se trate dun sufixo de abundancia, presente en cornutus, carnutus e pilutus, (cornudo, carnudo e peludo), e no que, quizaves, se esteara tanto a formación dos sufixos participiales en -UDO e o seu desenvolvemento, como no participio orixinario.

Sobre deste sufixo -UTUS parece terse feito outro en -U(T)TIUS, como sobre -UCUS se fixo -UCIUS ou -UCEUS. Dun deles salíu o gallego -UZO de «Cuzo», «ruzo» e outros, convertidos hoxe en sustantivos, algunhas veces.

-ACEUS/-ACIUS, foi moi usado no latín rústico pra derivar adxetivos de materia. Pero os que se conservan en gallego pasaron todos á sustantivos, como «angazo», «vagazo», «espiñazo», e, modernamente, queren ter un matiz aumentativo.

-ICEUS/-ICIUS mantén o seu valor de derivado adxetivo en moitos casos (afogadizo, alabadizo, brizo, calmizo), pero sólo cando se trata de derivados sobre adxetivos ou verbos. Cando os derivados están feitos sobre sustantivos, siguen a norma dos en -AZO. "Arañizo», «capizo», «canizo» e "cortizo», que foron en orixen adxetivos, son modernamente sustantivos, coa particularidá de que as novas formaciós tenden a regresar á forma culta, como dixemos dos derivados en -ITIA. «Rodicio», «bulicio», «estronicio» son hoxe formaciós correntes.

De orixe ibérico, o sufixo -AECU cruzouse aquí ó redor do siglo X co africano -ICCO, dando de resultas derivados en -EGO ou -ECO, como «valeco» e «rabeco» frente a «vilego», «chairego»e «soarego». Estes sufixos tenderon á confundirse co 
dos sustantivos derivados de -INGU. «Meirengo» e «millarengo» son deste tipo e «andarego» inda hoxe mantén as dúas formas, según as comarcas.

O sufixo -ICUS usábase no latín tardío pra derivados de nomes gregos, dos que quedaron algús en Galicia, como «crego», «pésego», este derradeiro coa variante «pexego» por cruce dos anteriores.

Foron moi importantes na derivación adxetiva -ALIS e -ILIS, que deron «lanzal», «sangal», «longal», «souril», «xentil» e algús máis, convertidos algús en sustantivos, como «fondal», «medianil», «cal» ou "canle». Son en Galicia de longa tradición (abbatiles en 880, carralem en 818). Con todo eso, non son moitos os adxetivos que del se derivaron. «Albar» e «molar» puideron derivarse do sufixo -ARE, que competíu con -ALE, ou ben ser resultados de disimilación, que é o máis seguro.

-ABILIS e -IBILIS, tan abundantes no latín cristiano tardío, non acabaron de callar en gallego. As formas históricas presentan estructuras en -ÁBELE e -IBELE. A lengua viva de hoxe tende a dar cabida as formas castellanas e escritores modernos, pola súa parte, non presentan seguridá nunha determinada forma.

Estaban pouco estendidos os sufixos -ANEUS, -ENEUS, -ONEUS e -UNEUS, mais deronnos algús derivados como «castaño», «estraño», «ferreño», «facareño», «roufeño», "pateño».

Foron moi fecundos os en -ANTE e -ENTE, derivados do participio de presente, (rallante, abafante, ardente e quente) e proliferaron sobre distintos temas.

O sufixo -ANU, como adxetival, usábase tamén moito, aparte da derivación de xentilicios. As formaciós históricas deste sufixo son abundantes (vilao, crischao, louçao, pagao), e viven aínda «mariñao», «chao», «brencellao». A evolución deste sufixo, como se sabe, non foi uniforme, e, na mariña de Pontevedra e da Coruña, con algús outros enclaves, non ben estudiados, deu -AN en vez de -AO.

Máis vivo que -ANU é hoxe -ANE, -ONE (-AN, -ON en gallego) Este sufixo, que debemos a unha influencia xermánica, nun comenzo non foi máis que unha variante morfolóxica introducida nos temas en - $a$ - e en - $o$ - da primeira e segunda declinación, pola que pasaban moitos destes sustantivos de temas vocálicos á ser temas nasales da terceira, pola adición dun infixo en -N-. Este infixo apoñíase preferentemente á nomes propios, mais co tempo pasóu tamén ós comus, e desde a época do Imperio atópanse inscripciós con nomes como barbani, de barba, mamani (o noso mamai) de mama. 
O feito de apoñerse este infixo á nomes de persona fixo que o conxunto sufixal -ANE, -ONE, se cargase axiña de valores afectivos e a homonimia do antigo sufixo -ONE de que antes falamos (nasonem, bibonem) fixo o resto.

Estes sufixos sirven hoxe pra derivar intensivos sobre temas verbales. Os en -AN son case sempre de matiz despectivo. Así en «nugallán», "papuxán», «vergallán», «langrán», «cirolán», «barbuzán». Os en -ON prefiren non acentúa[r] tanto o matiz despectivo (tardón, zugón, roulón). Aplicados á animales e cousas, non pasan de intensivos. Cando teñen matiz despectivo, alternan cos en -ÁN. Así «zarapallón»ou «zarapallán», «larpón» ou «larpán», «larchón» ou «larchán».

É moi antigo o sufixo -ARIU pra formar adxetivos, e a súa historia por eso é un tanto compricada. Nun comenzo eran denominativos e denotaban relaciós físicas de ocupación, polo que pasaron a sustantivos (tabernarius, pomarius). Estes derivados eran correntes no latín romanceado de Galicia no que atopamos nogaria e ferrarius xa sustantivados e lignarius e ferrarius adxetivados aínda con faber.

Non tardóu -ARIU en cargarse de outro matiz e espresóu entón a inclinación, amor ou tendencia de unha persona por unha ocupación ou oficio. Deste xeito «cabaleiro» como adxetivo, sinifica amigo de andar a cabalo, «meniñeiro», amigo dos nenos, «caseiro», amigo de estar na casa, «artimañeiro», inxenioso, «compangueiro", de carácter conciliador. Con esto pasóu o sufixo -ARIU á ser espresivo dos caracteres morales das personas, como «bulideiro», «falangueiro», "cantaroleiro». Sobre temas adxetivos atenúa o valor do simple. «Tristeiro» sinifica algo triste, con tendencia á tristeza, "alteiro», de talla mediana, "cativeiro", que tende a ser pequeno, «velleiro», avellentado. E así «delgadeiro», "grandeiro», "pequeneiro». Con este valor, son sinónimos de derivados en -ETE e en -OTE. «Delgadeiro» e «delgadete», «cativeiro» e "cativote».

Como en castellano, os deverbativos en -EIRO espresan a posibilidá da acción. Así «casadeiro» e "pasadeiro» valen tanto como home que está pra casar e cousa que pode pasar.

Os derivados en -OSO teñen distintos matices. Aparecéu axiña pra derivar adxetivos denominativos. $\mathrm{O}$ «Appendix Probi» corrixe: rabidus non rabiosus. $\mathrm{Na}$ lengua literaria da Edá Media son moi correntes. «Viçoso», «fremoso», «saboroso», "precioso», "preguiçoso», "proveitoso», "porfioso», «oufanioso», son palabras que ocurren á cada momento. Por todos estes exempros non parece que se poida 
ver neles outro matiz que o de espresar sinxelamente a coalidá do sustantivo que lles sirve de tema. Mais, debido á sinificación especial de algús destes temas, adequeríu un matiz intensivo, que notamos ben en derivados como «barroso», moi abundante en barro, «areoso», «folloso», «arestoso». É propio do liño en xeneral o ter arestas. "Arestoso» é o que ten moitas, polo tanto.

Non conta este sufixo con moitos derivados de verbos e adxetivos. "Apestoso», «verdoso», «aleivoso», «amargoso» e «dulzoso» quizaves señan a maioría dos representantes.

Pra adxetivos xentilicios usouse moito o sufixo -E(N)SE, que deu -ÉS, e que loitóu con /-ANU neste oficio. Foi de moito uso no latín eclesiástico. Nun Parochiale suevo do ano 569 úsase con esclusión de calquer outro. En gallego deu moitos derivados (lugués, padronés), pero non se pode decir que desbancase ós seus competidores vulgares, dos que aínda viven, que eu seipa, "mariñaos», da Mariña, «galgueños», de Galgao, «vilegos», de Mondoñedo, «meirengos», de Meira, «valecos», de Lorenzana. De calquer maneira, frente á todas estas reliquias dos antigos sufixos populares trunfóu -ÉS, de orixe culto, debido ó estraordinario influxo do latín eclesiástico en Galicia.

Co sufixo de axente en -TOR derívanse moitos adxetivos sobre temas verbales que denotan a tendencia e propensión ou habilidá do suxeto. Deste tipo son «enmeigador/-a», «cantador/-a», «falador/-a», «loitador/-a».

Pra rematar, faremos mención aínda do sufixo -IVUS, que, si hoxe non é vivo máis que en certos cultismos, entra na formación de moitas palabras gallegas desde os comenzos da lengua. Presenta dúas formas: unha culta en -IVO, sobre a que se asentan palabras hoxe tan comús como "cativo», «esquivo», "nativo», "chamativo», e outra vulgar, en -IO, sobre a que descansan "esquío» e "esguío», ambos relacionados con «esquivo», que non axusta, e todos eles con cadivus da época imperial, «vadío», «bravío», «estantío» e outros.

Algús destes adxetivos pasaron a ser sustantivos. Así «estivo», centeo ou trigo sementado en terras labradías, frente ó do monte que se sementa nas rozas recén cavadas; «armentío», o gado do monte, que anda en rebaños; «agrío», as terras que estan fora das chousas que rodean as casas, nos agros de moitos veciños; "prantío», terreo dedicado á arboredo, etc.

O mismo na derivación verbal que na de sustantivos e adxetivos, o noso tempo señálase por unha marcada importanción de cultismos na que tornan á 
revivir gran parte dos que formaron o fondo da derivación latina. As creaciós vulgares dos distintos romances ceden diante as cultas e puidera estar cerca o tempo dunha nova lengua común da Romanía, siquera que seña unha lengua técnica pra xentes que se cruzan tódolos días nas grandes rutas aéreas das novas pelerinaxes.

\section{Derivación analóxica, [importada e regresiva]}

\section{1. [Derivados analóxicos]}

Cando unha palabra toma un sufixo que non lle corresponde, chámase, un derivado analóxico, de imitación como si dixéramos. Tamén nas palabras se dá o caso de aparentar o que non son.

Traballa este fenómeno de distintas maneiras. En palabras gallegas tende á trocar a terminación por outra máis espresiva, ben por atracción de outra palabra, ben libremente. "Cónchega» de concha, "píntega», de pinta, "bóchega» de bocha son outras tantas derivaciós analóxicas orixinadas por outros proparosítonos que hai en gallego, como «néciga», «réciga», «cóbrega», «cóbado», «bóldrega», «apóutega», «aldáldora», «cómbaro», das que algunha tampouco é orixinaria.

Nos nomes de prestado, con terminaciós raras, ten a analoxía o seu lugar natural. De dente de dragón fixo «dentagrón» e «dentabrú»; de eucalipto, «cálitro» e «alcolito»; de ciprés, «alcipreste»; de parálisis, «paralís»; de arsénico, «sénica».

Sobre este punto é curiosa a historia de «réciga».

Xa debe haber bastantes anos que aparecéu polo norte de Lugo un colchoneiro castellano. Éste deixóu a palabra «renchir» pra sinificar o feito de encher os colchós de sedas crechas e cocidas ó estilo do país. Ninguén pensa no verbo castellano rehenchir, por demáis culto. É, nin máis nin menos, que un tecnicismo gallego, que non ten outro uso que o específico que lle señalamos. O dicionario de Valladares trai «rencher», pero, pola forma e polos sinificados que lle dá, teño de mín que é unha creación do autor, como outras.

O noso «renchir» non fixo máis que dar dous derivados: un, «renchido», que vale tanto como «tapizado» (sillas renchidas) e «blando» ou «molido», sempre 
aplicado a colchós ou tapizados, e outro, «réciga», que sinifica «sedas aparadas pra facer colchós» ou «as sedas dos colchós». Como de «renchir» se chegóu a «réciga» é o que non sei. O derivado regresivo que cabía esperar era «recha». Por eso cremos que «réciga» é un derivado analóxico, como o é «limáchiga» de limacha.

Outro tipo de analoxía é o que vemos na alternancia de terminaciós, sin matices semánticos que se perciban, de moitas palabras gallegas, como «comiscar» e "comichar», «lambiscar» e «lambuscar», «curruncho» e «currullo», «maceira» e «mazaira». É un caso propio das lenguas faladas. Si se tratara de unha lengua escrita, o sufixo máis vivo houbera dado conta do menos estendido. Nunha lengua coma a nosa pode vivir acurrullada nunha aldea ben pequena unha palabra que desaparecéu do resto de Galicia hai centos de anos.

Os encontros homonímicos de moitos verbos en -AR fixo desenvolver moitas terminaciós analóxicas en -EAR/-EXAR. «Abalar»e «abalear» («abalar o neno»e «abalear as castañas»), «encalar» e «encalear», («encalar as patacas» e «encalear a casa»), «alumar» e «alomear» (pouco aluma a luz, aloméame cunha vela), parecen ser reacciós da lengua contra casos de homonimia que levan a morte segura ás palabras. A aparición dos verbos castellanos «acunar»e «alumbrar» e a restricción de «branquear» pra sinificar «calear», son as vísperas. Outros verbos teñen alternancia de sufixo sin variar o matiz. É o caso de «troular» «troulear», onde a alternancia é pura analoxía.

Por analoxía dos derivados orixinarios en -CIÑo (enciño, veciño) moitos diminutivos en -IÑo toman esa forma, alternándoa coa propia. Así «pauciño» e «pauiño», «animaliño» e «animalciño». Hai casos en que pode ser por dificultades fonéticas. Pero mellor creo que a distribución e alternancia de -IÑO e -CIÑO se deba á un esforzo da lengua pra desfacerse de homonimias fatales. Ninguén di de "pan», "paniño», pero as razós pra non facelo non son fonéticas, senón que é o medo a homonimia de "paniño", derivado de "pano». De «man» podíase facer «maniña», pero «maniña» é un adxetivo que sinifica vaca cinlleira. De «mal», enfermedá, non podemos facer «maliño», que é un adxetivo, senón «malciño». Esto, repetido en varios casos, leva á alternancia de raíz analóxica que vimos. 


\section{Sufixos importados}

Coma as palabras, os sufixos sufren as súas renovaciós, e polas mismas causas. Hai xa tempo que o sufixo castellano -ERO entróu en Galicia pra desinar cousas, oficios e tecnicismos varios, importados polo comercio, polos segadores e polos emigrados en xeneral. Inda que hai unha concencia clara dos dous sufixos irmáns, entran ás veces en competencia, e non sempre se fai a tradución. A razón de que esto ocurra é que se trata nus casos de evitar homónimos de mal gusto. «Verdadeiro» non casa ben con «mentiroso» e tratóu de buscar un parónimo no castellano. Atopóu «embostero». É visto que polo mismo que o buscóu non tardaría en galleguizalo, pero, ó facelo, aparecería unha palabra con cheiro a corte de vacas. E quedóu en «embostero».

Outras veces non se fai a tradución de -ERO en -EIRO por desconocer o carácter de derivado que ten a palabra ou por certo aire de distinción que se lle quere dar á cousa, oficio ou istrumento que sinifica. Casos do primeiro tipo son «cañotero", «pistero», nos que non se sinte máis o sufixo que en «sicudero», unha formación orixinal de Galicia sobre o latín litúrxico.

Do segundo, "gornicionero», «trinchera» e outras. Está ben que se chame «albardeiro» ó que fai albardas e albardós. Pero non se pode emparexar con él ó que fai sillas. Os soldados gallegos, ó voltar da guerra, falaban de "parapetos» e «trincheiras». As que traían ó lombo, por eso, chamábanlles «trincheras» e «gabardinas».

En xeneral, pode decirse que os nomes de cousas especializadas que teñan este sufixo castellano quedan con él en gallego, sin ningunha tradución, a non ser que se trate de cousas de uso moi xeneral e vulgar. "Porteiros», "consumeiros», «rancheiros» son palabras relativamente novas no falar das aldeas e están galleguizadas, pero non o están «cristaleras» e «rinconeras» que viñeron botar fora das cociñas distinguidas as espiteiras e cunqueiros ou cazoleiros. E non o están por ser invenciós novas, sinón por ser cousas finas. Prendas de vestir que xa desapareceron, como as «bajeras», e louzas finas, como as «poncheras» de Sargadelos, deixaron pasar os anos, perderse Cuba e acabarse o rón e os ponches sin galleguizarse.

Pasa o mismo con -ILLO, -ILLA, e -INO (-ELO, -ELA e -INO en gallego). As «puntillas» e «mantillas», como as «natillas», son do tempo da mantela, do man- 
telo e dos cachelos. Non máis aló do XVIII, pero tampouco máis acó. E unhas galleguizáronse e outras non. Antigo é o sufixo de "xustillo», antecesor de corsés e faixas, e os panos de «marino» viñeron coas «estameñas» e «franelas», galleguizadas... antes de chegar a Galicia.

Aparte estes sufixos castellanos, inoperantes na vida dos sufixos gallegos, pero que poden fillar co tempo e renovar deste xeito a nosa sufixación, están os numerosos sufixos cultos do grego e do latín que entran á montós no gallego e que máis terán que entrar, si esta lengua chega á ser de cheo literaria.

$\mathrm{Xa}$ vimos o ésito do sufixo -AL, de orixe culto, sobre -EDO, -OSO e -EIRA, pra desinar topónimos de árbores, e o de -ACIÓN e -ICIÓN, que vemos restaurados en «animación» e «bendición», sobre -AZÓN e -IZÓN. Pero aquí referímonos máis ben ós sufixos cultos que desapareceran totalmente nas formaciós vulgares, debido á erosión fonética, como -ULUS e -CULUS, que aparecen nos cultismos de hoxe «óvulo» e «ridículo». Destes sufixos reapareceron -ICO en "político» e "histórico», "cómico»; -FICO e -FICARE en "manífico», «frigorífico», «beatificar», «dulcificar» e noutras moitas palabras.

Alfonso X decía:

¿Qual é a santivigada

Ante e despóis que foi nada?

Tiña razón pra eso. Escribía nunha lengua común sin meirandes compricaciós de tipo intelectual. Hoxe as lenguas teñen necesidá de precisión pra espresar con xusteza os matices dun número crecente de abstracciós. O sufixo -ATUM deu -ADO en gallego. Pero o -ADO de «aixado», «sollado», «tellado» e «lousado» non nos sirve para darnos o sinificado que lle damos á -ATO en «patronato» e «concordato».

Dígase o mismo de -TORIO. Co sufixo de «corredoira» e "lavadoiro», é visto que non decimos o que se quere decir en «requisitoria» e "conservatorio», aparte de que estes dous cultismos non son tan novos en Galicia, debido á lengua relixiosa.

No campo das cencias, os casos son máis vivos, estando, como está, ligada á determinados sufixos a espresión da estructura dos derivados químicos, verbigracia. 
Pola súa maior riqueza e por non estar gastados polas lenguas vulgares, os sufixos que a cencia hoxe utiliza con preferencia son os gregos.

$\mathrm{Na}$ Edá Media usáronse moito como cultismos -ISMO e -ISTA pra señalar as escolas e os seus defensores (tomismo, escotista) e siguen moi estendidos pra desinar bandos políticos, tendencias artísticas e as xentes que figuran neles ou que as siguen. Fora destes dous sufixos gregos poucos máis salen do dominio centífico, nas súas distintas ramas.

Deixando aparte outras -a retórica e poética, introducíu moitos desde o Renacimento- a cencia que especializóu os sufixos gregos pra desinar series enteiras de produtos, que hasta certo punto é o oficio dos sufixos, foi a química cos seus «carbonatos», «fosfatos», "celulosas», "glucosas». Moitos destes sufixos son creaciós arbitrarias, como os sufixos en -ENO, -URO, -INA, -IDA, etc., pero teñen unha seudomórfosis grega e, sobre todo, función de verdadeiros sufixos.

Tanto éstes, que se presentan seriados en moitos nomes, como os que aparecen islados, quedan marxinados na vida dos sufixos comús, por unha ou outra razón, pero hai casos en que entran en competencia con eles, como vimos no caso de -ERO e veremos aquí con outros sufixos.

Pode ocurrir que queiramos facer o derivado de unha palabra e que esteña xa feito con outra sinificación. Ós que veñen cantar ós enterros e festas de aldea non se lles pode chamar "cantores», porque é unha desinación común de todo aquel que canta, e eles son homes de oficio. Non se lles pode chamar «cantadores», porque é un adxetivo que se aplica por igual a carros do país, galos e mozos das festas, pra indicar que cantan ben e que teñen disposición pra eso. Como non se lles iba chamar «canteiros», chamáselles entón «cantistas». De maneira parecida nacéu «ramista», que é o devoto que paga a festa e leva o ramo diante o patrón, "calista», que é o albañil, desconocido en moitas aldeas onde aínda son unha que outra as casas brancas, e, con eles, outros moitos, de xeito que este sufixo, cun valor semicultista, pasóu xa a formar parte da vida do gallego.

Onde se nota tamén o gusto polos sufixos cultos é nos derivados de nomes de vilas grandes e pequenas. A non ser nos documentos latinos non se conocían hasta hai pouco outros derivados que os de cada día: «betanceiros», "chairegos», «lugueses», «ourensinos» e outros así. Hoxe hai xentes que sinten verdadeira necesidá de buscar outros derivados máis finos, que mostren, un orixe máis distinguido, e aparecen entón os de «brigantinos», «mindonienses», «lucenses», «aurienses», e «vilasabrosinos». 
Non pasa, é visto, de ser unha moda, pero na historia das lenguas, coma nas outras, a moda ten a súa importancia.

Neste e noutros casos, quizaves seña por demáis o afán de buscar neoloxismos. Pero hai que reconocer que este afán responde, no fondo, á unha verdadeira necesidá, que arrinca do mismo ser da lengua. "Achousar» é un verbo que sinificóu "cerrar ben a porta». Antes del houbo outro, que foi "choer», coas variantes de «chuir» e «achuir» en algunhas comarcas, que sinifican tamén arrimar a porta ou cerrala con cuidado. Xa se usaba na Edá Media «sarrar», pra decir o mismo ou case o mismo, e non conto «aferrollar», «acarabillar» e outros.

Todos estes verbos viven hoxe, máis ou menos mutilados na sinificación, pola maneira especial de ser do gallego. Algús, enquistados nunha frase fixa, cristalizada. Pero de calquera xeito viven. Alguén puidera crer que nos sobran verbos pra tódolos matices de cerrar, e con razón. Pero si tratamos de espresar o feito de dar fin á unha asamblea, á un curso de conferencias ou estudios veremos que ningún deles nos serve, e teremos que botar mau de "clausurar», como fan hoxe tódalas lenguas romances. Están no mismo caso outros sufixos e outros derivados, como "pacifista», "pacificar», "estilizar», portadores de valores novos que non poden ter espresión na lengua de outro mundo e outra xente.

\section{Derivación regresiva}

Así como un derivado propiamente dito ven amecer un sufixo ó primitivo, alongando deste xeito a palabra, cando aparece un derivado máis curto que o primitivo, temos un caso de derivación regresiva, que ven pra atrás en vez de ir pra diante, que era o que lles pasaba ós poltros de Caabeiro.

Non é un procedimento novo. En latín había algús verbos que sobre o derivado normal, salido do participio, retoñaban outra vez e daban un novo verbo. Salire, poño por caso, deu saltus e sobre saltus aparecéu saltare. Neste caso é un procedimento normal. Trátase dunha cadea de derivados, na que cada un se esprica polo outro. Mais, si suprimimos o primeiro, salire, saltus non ten en que apoyarse, porque non pode proceder de ningunha forma de saltare. Estas formas así son as que reciben o nome de regresiós e son derivados analóxicos.

No latín vulgar foi unha das primeiras formaciós regresivas a palabra prode, tirada de prodesse. O verbo prodesse perdeuse, pero ela vive en moitas lenguas 
romances. Emprégana os poetas dos Cancioneiros, coa forma "prol», e inda hoxe se escoita en algunha frase feita. Tiña o valor de «proveito». Co valor de «importancia», é unha importación de Castilla.

Este procedimento é moi común na lengua popular, inda que limitado en xeneral á derivados verbales en -A. Sabemos moi pouco del nos tempos medios. En Eans Mariño (C.V., 1154) atopamos "chufas», que non nos atrevemos sin máis a asegurar que seña un derivado regresivo de «chufar». Pero non hai medo á errar en supoñer que estivese tan vivo este fenómeno coma hoxe. O nome da maior parte das laborías está formado por esta clase de derivados. Así a «sega», a «malla», a «sacha», a «fía» do liño, a «calda» dunha ferramenta, a «crabuña», a «calza».

Algunhas veces alternan os derivados normales e os regresivos, como en "queima» e "queimadura», «fenda» e «fendedura», «sacha» e "sachadura». Pero hai que ter en conta que non teñen o mismo matiz por completo, anque os confundan algunhas personas.

A «vira» é a simple acción de dar volta á herba segada pra que se cure. Unha «viradura» é cada unha das «viras» que se lle dá. Supoñamos falando á dous paisanos.

-«Fai bon sol pra virar a herba».

-«Falta fai, que a miña está de mala vira».

-«Bueno, pero eso no’ é máis que na primeira viradura». 


\section{A VIDA ÍNTIMA DAS PALABRAS}

\section{CAMBIOS DE FORMA}

Viñemos estudiando hasta aquí, á grandes saltos, os cambios que se levan operado no vocabulario gallego á partir do fondo orixinario latino de onde arrinca, así como os operados nas súas fontes de renovación, composición e derivación.

De aquí pra diante estudiaremos a vida íntima do vocabulario, algús aspectos da loita xorda que se libra entre as palabras por razón da súa forma e do seu sinificado, o principio de costante renovación que radica no fondo de cada individo e de cada sociedá, e os secretos camiños que sigue.

Comenzamos polos cambios de forma que se dan nas palabras debido ás loitas que teñen que manter coas compañeiras con que lles toque en sorte convivir na frase (cambios sintácticos); cos falsos parentes que pretenden herdalas, basándose no parecido (contaminación paronímica); co afán de medro egoista que mostran algunhas na frase, que acaban por desbancar ás outras e quedarse elas solas (elipse); coa presa ou desgana da xente que fala e sinte pereza de articulalas enteiras (abreviación); coa alegría de rexoubar do espíritu ledo dos nenos, que os leva a tomar as palabras como xoguetes (redoblamento).

Estudiaremos por fin noutro capítulo os cambios de sinificación que esperimentan por obra do espíritu humano, sempre en loita por atopar un camiño pra o sentir cambiante de cada día (cambios de sinificado).

\section{A vecindá na frase}

Frente ás lenguas céltigas, en que os comenzos das palabras penden en moitos casos dos finales das precedentes, perdéndose deste xeito a súa individualidá, as lenguas latinas caracterízanse polo sentimento dela. O gallego, por lengua falada máis que nada, resintíuse en algús casos, siquera aparentemente, desta pasividá. 
As palabras que orixinariamente comenzaban por $C$ - ou $P$ - trocaron estes fonemas por $G$ - ou $B$-, en algús casos. ¿Revelarán con eso que nun período histórico estiveron sometidas á esta lei de pasividá de algunha maneira?

"Grade», "gaiola», "gruño»e «brume» (supuración), «bostela» e «balor», orixinarias todas de palabras latinas con $C$ - ou $P$ - iniciales, son algús dos testigos.

V. García de Diego supón que se trata de casos islados que pode espricar a analoxía paronímica de outras palabras. Meyer-Lübke esplica a sonorización de $P$ - e $P$ - polo contacto do artículo con estas oclusivas, co que mantén a lei de pasividá, siquera reducida á un caso concreto.

Non é doado decidir, nin partindo do estado actual da lengua, na que puido operarse unha regresión, nin da literatura medieval, sabia e analítica por demáis. É verdá que ainda hoxe temos algunhas formas oscilantes, como "carabullo»e "garabullo», "camalleira» e "gramalleira», «carafeto» e "garafeto». Pero non son propiamente sentidas como tales, porque dentro de cada comarca é uniforme unha delas, e de ahí que non representen un estado de oscilación real, que probaría a tesis de Meyer-Lübke.

Por todo esto e pola tendencia xeneral das lenguas neolatinas, cremos con García de Diego, que se trata de casos islados de atracción paronímica.

Máis importante foi a lei oposta da loita pola individuación que mantiveron certas enclíticas e proclíticas, coma os pronomes $-o,-a$, -os, - as e os artículos que teñen a misma forma. Todas elas, en vez de sufrir a acción das palabras que lles precedían, actuaron de atacantes, hasta o punto de desfigurar tódolos finales en consonante que viñan nesta posición. Cando estas palabras son fonéticamente fortes reaccionan atraendo ó seu grupo de intensidá os artículos, que deberan ir coa palabra que determinan ( $f a ́$-nas contas). Pero si son átonas, chegan á absorbelas, como lle pasa a «de», «en», «por» e «con».

A historia desta loita non deixa de ser interesante polas repercusiós que tivo e que trascenden da fonética á morfoloxía e á sintasis. Espresiós como estas: «o non fixen», «o non dixo», que veñen de moi atrás, teño de min que remontan a este período de loita.

Os resultados principales son os que siguen. De resultas de unha asimilación progresiva, -R e -S finales pasaron a L pola acción do L primitivo de «lo», «la», «los», «las», e por asimilación regresiva, este primitivo L de «lo», «la», etc, pasóu 
a $\mathrm{N}$, despóis de $\mathrm{N}$ final, dando $\mathrm{NN}$, que se simplifican regularmente, como se simplifican LL, orixinarios ou non.

O máis importante desto é que todos estes fonemas finales, despóis da súa asimilación e simplificación, se desprenden do grupo fonético anterior e pasan ó grupo fonético do pronome ou do artículo, inda que, por reacción, queden unidos ó grupo tónico. Todo esto se poderá ver nos casos que siguen.

Artículos con verbos: «Non va-las orellas dun can cheas de auga», «agora sa-lo criado»; «din que ve-no rei»; «vou ve-las festas»; « ¿dáde-lo caldo?».

Artículos con outras palabras: «non é o ma-lo peor»; "pedían pa-nos pobres»; «tiñan caló-los animás ou ca-ló-ros animás». (Neste último caso hai que decir que o fenómeno é menos percibido).

Pronomes con verbos ou con outros pronomes: «Fixéro-na boa»; «matá-los é pouco»; «di-lo ou non?»; «deuno-la él ben dada»; «iinda non vo-las deron?»; «xa lle-lo dixen».

Como se ve, os artículos e pronomes fillan en diversas formas: «o», «a», «lo», «la», «no», «na», e o artículo, aínda en «do», «da», «co», «ca» ou «coa», «polo» e "pola», cos plurales respectivos, pero quedan reforzados na súa posición mentras que as palabras que lles precedían quedan mutiladas.

As formas pronominales «no», «na», «nos», «nas» úsanse coas terminaciós diptongadas dos verbos. Así en «viu-no», «deu-na», «levou-nos», «mirai-nas», «levei-no», «roi-no».

«Non» diante estas mismas proclíticas, ten distinto trato según a súa pronunciación máis ou menos enfática, ademitindo as gradaciós de «no-nas vin», «no-as vin» $\mathrm{e}$ «nas vin». Cos pronomes «me» e «nos» e os compostos «mo», «ma», «mos», «mas», «nolo», «nola», «nolos», «nolas» limítase a perder o $-N$ final, como en «no me dixo nada», "no no-lo fai ni no-lo pensa facer». Cando se acumulan deste xeito dous ou mais grupos fónicos, «non» faise tónico e atrái ó seu grupo os pronomes que lle siguen: «Nó-no-lo», «ní-no-lo».

«Con», diante os artículos, presenta tamén as variantes «ca/coa», "cas/coas», que dependen de factores personales moitas veces. Coas formas tónicas dos pronomes personales «él», «éla», etc. e demostrativos «éste», «ése», «áquel» mantense o $-N$ case sempre. As formas "co él», "co ela», etc. parecen localismos, coincidentes, polo que teño observado, coas variantes «il», «ise» e «aquil». 


\section{Aglutinación e deglutinación}

As lenguas clásicas apenas si sufrían alteración ó comenzo de palabra, debido ás que lle precedían, pola especial estructura do reximen, que non esixía enlaces habituales. Pero cando comenzaron á multiplicarse as partículas e os artículos diante os sustantivos, viñeron as malas percepciós e as desfiguraciós, unhas veces, porque a partícula se funde coa palabra que sigue, e outras, porque ó desprenderse dela, leva consigo un ou máis fonemas.

Cando o artículo se funde coa palabra que leva diante dase un caso de aglutinación. Si o artículo lle leva algús dos seus fonemas, chamáse deglutinación.

Neste, como noutros moitos casos, non podemos presentar un resume histórico dos feitos por carecer de estudios monográficos, e contentarémonos con dar algunhas mostras que de momento se nos ocurren.

Ambos fenómenos ordénanse particularmente ó redor dos artículos «o», «a», «Os», «as». Abundan nos locativos, como «o Grobe», que aparece nos documentos «Ocobre» e «Ogobre». Non faltan tampouco no lésico común, no que son casos destes «alache» (lorcha) «alanterna», «amalló», «amenta», «amora», «apóutega», «abidueira» e «sombras». De deglutinación son: «(s) ofraxe», «(o) bispo», «(s) argazo», "(a) loia», "(a) bodega», "(a) postema», «(o) brosa», «(a) bolito».

\section{Contaminación e atracción paronímica}

Pra producir alteraciós unha palabra noutra non precisa estar en contacto con ela. Basta que as dúas figuren nunha misma familia, ben por semellanza de son (homónimos e parónimos), ben por semellanza de sinificado (sinónimos). Entre dúas palabras de forma semellante, pero non igual (parónimos) sempre que se asocien ideolóxicamente, acaba por producirse unha contaminación profunda que non consideraremos aquí máis que no seu aspecto formal. $\mathrm{O}$ parónimo de máis uso e máis forte, polo tanto, fará derivado seu ó outro, co que se farán máis semellantes aínda. "*Abruño» entróu na área de agre; "*arundiña» na de andar e «ferrollo» na de cerrar, por unha doble coincidencia de forma e sinificación, e apareceron, de resultas as formas de "agruño», «anduriña» e "cerrollo».

Pasa o mismo en "gavión», refeito sobre ave en «avión», nome de distintas especies de aves. "Beixar a cruz» tornouse en «baixar a cruz» nun dos actos 
litúrxicos de Semana Santa, co que se chegóu á homonimia. A analoxía ideolóxica operouse polo feito de que pra beixar a cruz, esposta sobre o chao da iglesia frente ó monumento, os devotos teñen que baixarse. Os resultados aquí son máis profundos. Baste señalar que nas comarcas en que se deu este fenómeno dise «chuchar» por «beixar».

«Sanguiño» chámase «sangumiño» e «sangubiño», por atracción de viño e "chiscar o ollo», que xa é unha atracción paronímica, sobre a interxeución «chis», pasa a «choscar» por atracción de «chosco».

En todos estes casos a contaminación provén de unha doble asociación paronímica e sinonímica. Noutros actúa nada máis que a primeira aparentemente, inda que non sabemos sobre que secretas relaciós, fora das fonéticas. «Contaminar» faise "contraminar», sobre "contra» e «amortuxar», de derivarse de morte, faise «amartuxar» sobre «martuxo», sin que vexamos ningunha relación semántica, como tampouco se ve entre «remedar» e «mendar», a pesar de que sobre este último se convertíu en "arremendar» o primeiro.

Este fenómeno dase en algús casos polo que se chama cruce de sinónimos e consiste nun encabalgamento de grupos fónicos de duas palabras sinónimas. Cita moitos casos destes García de Diego, como «carafuncho» que supón cruce de caruncho + furuncho; «pingotas», de pinga + gota. Parece que desta maneira hai que esplicar en gallego moitas palabras. A partir de «engurrar», «engruñar», «enguerellar», «engueimar», e «avellar», quizaves que se puideran esplicar outros como «engurrumiñar», «engorromellar», «engorrovellar» e «engurrullar». Pero non parece que se deba estender por demáis este procedimento, que non fai falla supoñer pra espricar moitos dos fenómenos e que outras veces non pasa de ser un espedente pra salir do paso. A atracción paronímica sinxela, ou compricada con xeminaciós afectivas e outros fenómenos lingüísticos que iremos vendo, abonda pra espricar moitos deses fenómenos. E si non abondan, tamén poden quedar sin espricar. "Condanaxar», que se supón feito por un cruce de "condenar» e «conxanar» non parece que seña outra cousa que o resultado da misma forza que deu «conxanar». Tanto «condanaxar» como «conxanar» son desfiguraciós de tipo eufemístico relixioso de «condenar», unha palabra prohibida. Ambas se relacionan con «condenar», pero non entre sí, visto haberen sido sempre a misma cousa.

Cando aparece unha palabra islada, latina ou estranxeira, inda que non se entenda, altérase conforme á grupos fónicos semellantes de outras palabras do 
país, que lle prestan o seu sinificado. E o que se chama etimoloxía popular, por máis que se trata dun fenómeno espontáneo e incoscente de todo, de tipo paronímico. A palabra "pedamigo", que se interpreta "pe de amigo», puidera ser o primeiro representante en gallego deste tipo de fenómeno. Sinifica o soporte que leva o pino do carro por debaixo pra que, ó dexunguir o carro, non finque na terra. Eu supoño que se trata dun tecnicismo derivado de pedamen e que entróu moi tarde no gallego, á xuzgar pola estructura fonética, no que «amigo» representa un sufixo superposto á pedamen. A palabra "Candeloria» é o representante do xenitivo candelorum refeito sobre "gloria», "palmatoria» e outras palabras deste tipo. «Cortafríos» fíxose «cortafíos», dente de dragón, «dentagrón»e «dentabrú», arcoiris, «alcolín»; oculista, «alcolista»; parálisis, "paralís» e apendicitis, «pendicites». De todos estes exemplos podemos formar un grupo con «cortafíos», «paralís» e quizaves «candeloria», refeitos por atracción paronímica normal sobre «fio de alambre», "parar» e "palmatoria», entre as que podían establecer algunha relación semántica coas palabras modificadas. En "pe de amigo» non vexo esta relación por ningún lado, pero vese a actuación de grupos tónicos da lengua na súa articulación. Nos restantes casos as palabras refanse sobre a base de reducir as sílabas estrañas á outras parecidas, pero sin relacionalas con ningunha outra palabra. O Gloria patri, rezado polos paisanos convírtese neste latixo: Gloria patre e de filio e de spirito santo. Sicudera nun principio e nunca e sempre e de en sécola seculorum. Danse aquí tódolos casos que poden ocurrir. Atracción paronímica simple en patre, filio, espirito, santo, principio, sempre, interpretación semántica en $e$, de, en, nunca. Interpretación fonética cega en sicudera, secola, seculorum.

Cando ocurre esto último, ás palabras resultantes infúndeselles unha sinificación aparentemente arbitraria pero que depende sempre de sutiles relaciós que se resisten a ser analizadas. "Sicudera» ten a sinificación de muller lixeira de cascos, pilla, argallante, e o mismo o correspondente masculino. «Sécolas», o de bromas, xogos, enredos.

Distinto do que acabamos de espoñer é o fenómeno de interpretación de nomes propios, que non se sabe o que queren decir, e aínda de palabras correntes que parecen compostas como "Castro con trigo», interpretación de Castrogondrigo, "Cardanachama», de Casdonachama, «Perdecanai» e outras, que son as verdadeiras etimoloxías populares. 


\section{Repulsión homonímica}

Cando por desgastes fonéticos, analoxía ou calquera outra razón, chegan dúas palabras á facerse homónimas, a lengua síntese en peligro e trata de poñelas á salvo. Dado que se fala pra que nos entendan, é natural que busque palabras que non se presten á trabucamento.

A maneira de reaccionar pode ser de dous xeitos: deixando que se perda unha das homónimas ou tratando de interpoñer diferencias entre as dúas, hasta convertilas de novo en parónimas. Cos sustantivos e adxetivos úsase preferentemente o primeiro sistema e cos verbos, o segundo.

Xa desde vello, temos un mismo verbo con formas paralelas en -AR e en -EAR. Orixinarios ou non, trátase de reaccións homonímicas. «Alumar» (este candil non aluma) e «alomear» (aloméame, estreliña), «esfumar» (tinguir con fume as zocas) e «esfomear» (convertir en fume unha cousa) parecen produto desta reacción.

Pode suceder que os dous homónimos cheguen á confundirse semánticamente, como pasa moitas veces no falar descuidado. Entón non cabe outra cousa que recurrir á un neoloxismo ou afondar as diferencias das duas palabras, recurrindo á regresiós etimolóxicas ou sufixos cultos, cando menos. "Atuar» (tratar de tú) e «atuar» (atascar) chegaron á homonimia, que quizaves manteñan en algunha comarca. O xeneral, con todo, é que se use na segunda sinificación «atuir»ou «atascar», que é un neoloxismo importado.

O verbo «tentar», entre outras sinificaciós, ten a de «intentar», «apalpar», «tomar en peso unha cousa», «ver si unha res está en celo» e tamén "probar»ou «medir as forzas, de parte a parte, duas personas ou animás antes de poñerse a loitar». Esta proliferación semántica débese á que en «tentar» están fundidos dous homónimos, un que provén de temptare, e outro, formado sobre tal. A reacción homonímica vese ben no parónimo «talentar» que é unha regresión, e que se usa no derradeiro sinificado que lle demos á «tentar».

Pra non caer nos incomenentes da homonimia, téndese á prescindir dos vocablos vellos, cargados de sinificaciós, cando se quere espresar un matiz novo, por pegado que apareza semánticamente. Así «asamblea», "clausura», «inauguración», tres cultismos integrales, frente á «xuntanza», «achousamento», «enceto», repudiados por outras razós afectivas que logo veremos. 


\section{Elisión}

Fora dos recursos ordinarios de importación, composición e derivación con que a lengua conta pra renovarse, dos que levamos dito, é a elisión un dos máis prolíficos. Consiste este procedimento en acumular os sinificados de dúas ou máis palabras sobre unha sola e desprenderse logo das que non son precisas, hasta quedar con unha nada máis.

Ten dúas caras, aparte o aspecto sicolóxico da concentración semántica. Por un lado ven á enriquecer o caudal dunha palabra cunha nova sinificación e, por outro, ven á espodar e repelar os labores brizos da parreira da fala. Ela é a que limpa nas guías hasta deixalas coma nervios vibrantes, á punto mismo de que se sequen, facendo ir e vir por elas o zume lóxico e afectivo que se estendía pola frondosa ramallada.

É un procedimento moi antigo, que retoñóu con moita forza nas lenguas modernas, pola necesidá meirande cada día de brevedá e pola proliferación, cada día tamén meirande, de circunlocuciós e rodeos, debidos á complexidá dos novos sinificados.

En toda espresión complexa hai dous elementos. Un, determinado, xeneral polo tanto, e outro, determinante e característico. O determinado parece natural que seña elidido, e foino desde os comenzos da lengua hasta os nosos días. A sustantivación do adxetivo epíteto aparece en cabeza na aparición deste fenómeno. De hibernum tempus, nace «inverno» e de veranum tempus, «vrao». De vestis alba quedóu «alba», na súa forma culta, pra indicar a prenda litúrxica deste nome. Xa máis tarde, de terras clausas e ruptias saliron as nosas «chousas» e «rozas»; de agros veteros, os «vedros» e de conca (?) ferrata, a "ferrada» da auga.

Nas lenguas modernas hai destas elisiós á barullo, que van dunhas lenguas pra outras xa feitas. Así «diario», de boletín diario; «negra», de nota negra; «eliminatoria», de proba eliminatoria; «dereito», de golpe dereito. Son palabras que non son de ninguén, precisamente pola súa estructura privilexiada. Pero o procedimento é de tódalas lenguas. Onde estóu escribindo dinme que acaba de pasar o "chato», que é un avión que presenta a forma dianteira moi recollida contra as alas e que comenzóu á chamarse «o avión chato». Si sallo á buscar tabaco ó estanco de enfrente, diránme si quero «rubio», «negro», «ideales», "canarios», «especiales» ou «hebra». Cando falamos de fumar, todos decimos que fumamos negro 
ou rubio, sin falar de tabaco pra nada, que é o determinado. Os labradores desinan deste xeito vacas e leiras. Nomes como «a nova», «a roxa», «a turrona», «a teixa», levan debaixo de sí un nome elidido.

O mismo que o adxetivo epíteto, pode quedar solo o complemento de nome. Os nosos topónimos revélano ben. «Gondariz», «Mondariz», «Reximil», «Baldomir», «Lois», «Aday», «Fanoi», e moitos outros, son vellos complementos de nome que quedaron solos despóis de perder o determinado, que era villa. Os complementos de nome romances, con «de», comenzaron tamén axiña á elidir o determinado. Cando Martín do Casal dí:

en quanto vai andar

a Granada meu amigo

elide «guerra de», como Golparro elide «romaría» cando dí:

d'ir ei coracón

a San Creecón.

Das elisiós de hoxe refírense moitas ós nomes dos produtos. «Ribeiro», "país», «peares», «valdeorras» son sustantivos que indican clases de viños e que elidiron esta palabra e a partícula de. En «orraca» elídese «peras de», como nas espresiós de «tráiame mondariz, guitiriz, sousas», etc. se elide «augas de». Cando no restorán pedimos un «lenguado», un «rodaballo» ou un «lacón con grelos», é visto que elidimos «plato de», e cando encargamos ó xastre «un mil raias» calamos «traxe de».

A elisión do determinante obedece a un mecanismo sicolóxico distinto. $\mathrm{Na}$ lengua de oficios e profesiós, a intuición contina do determinante fai que se asocie ó determinado. Pra un zoqueiro un «cepillo» e un «repinico» non precisan de determinante. Están intimamente relacionados co oficio e xa se sabe que son o cepillo e o repenico «das zocas». Pasa o mismo na lengua do gaiteiro e de tódolos oficios. Cando un paisano fala do roncón, refírese á un coleóptero dado, e si fala un gaiteiro, á outra cousa. Ambos elidiron o determinante. O mismo cando se fala de «fol» (da gaita, do muíño), de "punteiro» (da gaita, da escola) suprímese o determinante que corresponda, según a persona que fale. 
$\mathrm{Na}$ lengua medieval eclesiástica, cando se falaba da «obra» elidíase iglesia, como se elide hoxe tamén na misma lengua técnica cando se fala de «fábrica». $\mathrm{Na}$ espresión en verbo, que se encontra tanto nos documentos eclesiásticos, elídese sacerdotis. Nestas frases que leo nun documento, "o refertorio da Graña», «un frade de Carvallo torto», falta nas dúas o determinante, que é «do priorato».

O gallego de hoxe, como tódalas lenguas, ten moitas destas elisiós. Aparte as dos oficios e profesiós, que non se poden contar, están as da lengua de cada día, chea tamén de especializaciós según os lugares á que vaiamos, bares, oficinas restaurantes, cines, etc. «Díame unha entrada». «¿Quere gotas?». «No atopo a lista». Estas frases sin sentido son normales no cine, no café e na oficina.

A elisión do complemento directo do verbo empeza facéndose cando é moi xeneral e tamén nas lenguas especiales das profesiós. «Et foron ferir axuntados». «Viñan muy sañudos et muyto aviados por ferir». «Et tan grand era alí o puxar et o atropellar». (Da Crónica Troyana).

En todos estes casos se trata de verbos da lengua militar e de complementos intuídos: o «enemigo», que é o que se ten presente en todo o relato.

Da misma forma empeza a usarse nos Cancioneiros «querer», inda que, normalmente, leve de complemento «ben» (sustantivo) ou "gran ben».

Este tipo de elisión foise multiplicando co tempo. Na lengua labrega úsanse sin o complemento directo a maioría dos verbos transitivos que indican laborías. «Vou segar (o centeo), «gradar» (os pallares), «acueirar» (as patacas), «amontoar» (os tarrós). E do mismo xeito, os artistas din: vou «espoñer», os chauferes, «pisei todo o camiño» e os curas, «vou celebrar».

En frases de moitos elementos chegan á elidirse o determinado e un ou varios dos determinantes. En «bos días», «boas tardes». «¡Xesús!», hai elisiós múltiples, de modo que en algús casos non é doado saber que oficio ten a palabra que resume o valor do conxunto.

Por outro método, pero que leva ó mismo resultado, desínanse as encíclicas e as oraciós da Iglesia polas primeiras palabras con que empezan: Quanta cura, un Pater noster, un Gloria, un Te Deum. En todas estas espresiós hai a elisión do resto, porque esas palabras cárganse realmente do sinificado xeneral. A palabra misa era xa unha elisión no tempo da monxa Etheria, que tiña unha sinificación máis concreta que hoxe ten. Pasando o tempo, por unha xeneralización semántica da palabra misa, que se estendéu a todo o conxunto de actos litúrxicos que 
precedían á fórmula. Ite, missa est, pasóu á sinificar o que hoxe sinifica, coa elisión dos dous verbos.

Dunha elisión parte tamén a maneira de dar nome ós distintos alfabetos. En gallego chámase o "abecé» ou o «cristos». "Este neno aínda non sabe o cristos». Este segundo nome está formado pola elisión do determinado «cara». Na carilla do silabario en que viña o alfabeto figuraba unha cruz na cabeceira. De ahí chamarlle «cara de cristos». A forma «cristos» esplícase porque nun comezo quizaves se puxese debaixo da cruz, en latín, Christus, que os nenos interpretarían por analoxías de grupos fónicos, como deixamos dito, dándolle o valor semántico de alfabeto.

\section{División e redución}

Un procedimento distinto, pero que poñemos aquí polo que ten de abreviación, consiste en dividir a palabra por unha das súas xunturas fónicas e prescindir da segunda parte ou, ás veces, tamén da primeira. Pra facer a división non hai regla fixa. O mismo se pode facer un pouco máis adiante que un pouco máis atrás, inda que se tende á manter un final que non seña estraño por demáis.

Parece que foi un sistema que practicaron moito os celtas e os gregos pra nomes de personas. Os antropónimos xermánicos eran tamén reducidos, inda que nas latinizaciós solían darse enteiros. No gallego antigo atópanse algús nomes de persona reducidos, como «Pay» por Payo, «Men» por Mendo, «Roy» por Rodrigo.

O primeiro destes nomes reducidos parece ser unha forma doble de Payo salida do xenitivo, Pelagii. As outras serían analóxicas, e a mutilación do nome, en calquera caso, unha moda.

Nas listas de servos dos documentos medievales encóntranse tamén. Pero falta un estudio destes nomes, que son de moi diversas procedencias.

Máis novas, pero anteriores ó movimento mutilador actual, son outras reduciós como «Sabas», de Sebastián, «Anuncia» de Anunciación, e «Beta» de Beatriz. En todos estes casos parece que hai como un intento de dar unha terminación á parte que queda insente, de redondeala conforme ó ser da lengua.

$\mathrm{Na}$ redución moderna é outra cousa. Dase un corte limpo, por onde caia mellor, e tírase co final. Ocurre sobre todo nos tecnicismos médicos e nas nove- 
dás da industria, acentuándose cada día. «Bicicleta» xa había pasado a «dicicleta», pero imponse de novo «bici», como «auto»e «cine».

Non son estraños á este procedimento, en algús casos independentes dos que acabamos de citar, que son importados, a ironía, o eufemismo e outros secretos síquicos. En gallego é bastante antiga, tanto que moita xente xa a non entende nos versos de Rosalía,

\section{Anda meniña \\ cose o teu cos.}

Esta derradeira palabra é unha redución ablativa ${ }^{17}$ de "costas» e sinifica a parte superior traseira dunha camisa, na que se empleaba mellor tela. Era un tecnicismo de costureira, como «basta» por bastilla.

Moitos alcuños son tamén nomes mutilados. Así «Sabas», que xa dixemos. «Rafa», «Mano», etc. pertenecen ó primeiro tipo e son de moda.

Un método especial que está ganando tódalas lenguas de Europa e América consiste en formar palabras coas letras e á veces sílabas con que comenzan as que dan nome á unha sociedá ou empresa. Hai tempo que conocemos USA e URSS. O primeiro interpretábase Estados Unidos e o segundo Rusia, sin máis. Este derradeiro xa empeza a interpretarse «Urs», e, desde logo, así se interpretan outras moitas palabras como CREPA, RENFE, CROS, ONU, UNESCO.

A redución polo comenzo, moi rara noutras lenguas, non o é tanto en gallego. Como este fenómeno é de orixen fonético máis que nada, é natural que así seña, pois que o gallego, privado do soporte da lengua escrita, está por demáis traballado fonéticamente. Os nomes que se pronuncian á berros, coma os que sirven pra chamar polo ganado, os pregós das feiras e os nomes das personas, están espostos á esta mutilación cando non comenzan por sílaba tónica. $\mathrm{O}$ maior esforzo con que ésta se pronuncia fai que se perdan as outras, tanto as postónicas como as protónicas, que é o noso caso. Os nomes de «Merexildo» por Hermenexildo, «Chinto» por Xacinto, «Sindo» por Gumersindo, «Mingos», por Domingos, son reduciós deste tipo.

\footnotetext{
17 esta derradeira palabra. Trátase dunha redución ablativa] na copia.
} 
Nos prantos polo difunto, cando as sacas de casa, oise "jai, chada de min, chadiña!», que non é outra cousa que «desdichada». No fin do siglo pasado vendíanse nas feiras un pano castellano que os tendeiros pregonaban: « $\mathrm{i}$ dieciocho! ¡Bon pano!». Ben porque o tendeiro non pronunciase ben, ou porque os paisanos non percibiran certas articulaciós estrañas, o caso é que se lle chamóu pano de «Aciocho» e por elisión e derivación «Aciocheno».

\section{Redoblamento}

Consiste este método en crear palabras pola repetición dunha sílaba, que pode ser a primeira dunha palabra conocida ou ben calquera arbitraria. Foi un procedimento das lenguas primitivas, hoxe desaparecido totalmente, si non é na lengua dos nenos. Quedan, por eso, reliquias del en tódalas lenguas pra evocar ruxidos, estalidos, zumbidos, cantos de páxaros e berros de animás.

No falar dos aldeanos abundan estas onomatopeias que lles aforran a descrición de moitos movimentos e dan maior viveza e gracia ó relato. Onse tódolos días conversas coma éstas.

«Puxo a xerra de dous netos ó bico e coló-, coló-, coló, ¡hasta verte meu santo!».

«As perdices estaban alí, que benas oíra toda a tarde ¡cacará-caracacará!. Pillei a escopeta e o can e fun tras delas. Pero ós cen pasos, ¡burrr!. Estaban fogueadas».

E agora un relato de comadres: «Non sei que lles pasará ás Labercas de Rebordelo que as encontréi entre as tendas chou-chou-chou-chuchuchú».

Carecemos de datos de redoblamento no antigo gallego. É seguro que habería algús do latín, como "papá» e «mamá»; «neno» ven do grego, polo latín. Nos Cancioneiros hai algús refrás con reduplicación, como o de «lelia-lelia».

$\mathrm{Na}$ lengua viva de hoxe quedan moitos. «Au-au»e «bau-bau» son os nomes que dan ós cas os nenos e que sirven na lengua corrente pra describir o ladrido; «ibabá!» e «ibobó!» son interxeuciós de menosprecio; «bisbis» ou «miques-miques» sirve pra chamar os gatos; «ñuñu» e un nome infantil de padriño, "carrá-carrá» ou "carráncarránca» unha onomatopeia do andar lento e arrandeado; «tuto» é o nome que se lle da a un chifre de caña, e derivado del, «tutar», e así moitos máis. "Xanxaranxán» é unha palabra de puro xogo rítmico, sin valor ningún, formada sobre Xan. 


\section{Xanxaranxán}

de acabalo dun can.

Úsase, ás veces, pra cortar unha proposición que non lle convén á un, e neste caso está contaminada de outras palabras como "xa-xá», que queren decir, «ben te entendo, ben te entendo. Pero...».

A maior parte destas son de orixe onomatopeico. Hainas, como «alalá» e «lero-lero» que veñen á ser elisiós das que deixamos estudiadas, denominación de un recitado polas primeiras palabras con que empeza ou polas máis repetidas, sin deixar por eso de ser redoblamentos. «Papá», «mamá», «ñuñú», «nené» están formadas sobre as primeiras sílabas de padre, madre, neno e sobre a máis característica de padriño.

Outro tipo de reduplicación é a que sufren certas palabras na primeira sílaba e que parece ter un orixe afectivo en algús casos como «bamborrear», de borrear. Noutros casos trátase de derivados de redoblamentos onomatopeicos, como «cacarañar», "cacarexar», «atustullar», «besbellar», «tatabellar», feitos sobre tustus, bebello, e tatabello.

Os nomes de nenos formados por repetición son poucos. Os que hai nas vilas (Fifí, Loló, Lulú, Totó) son de importación. Nesto parece que hai unha reacción. Hoxe téndese á dar ós nenos o nome que resulta da pronuncia graciosa dos irmáus e compañeiros da súa edá.

\section{CAMBIOS DE SINIFICADO}

Tódalas anovaciós e cambios que sufren as palabras e que viñemos estudiando hasta aquí van acompañadas de cambios de sinificación. Pero o cambio semántico de unha palabra non sempre está sometido ó fonético nin precisa del pra aparecer.

Unha palabra, sin cambiar un solo fonema, pode ser influenciada na sinificación por un parónimo. «Arrequentar», formada sobre «rico», sinifica acrecentar, aumentar, como aumenta o pan no forno. Pero pola semellanza con «quentar» contaminouse do seu sinificado e, fora da lengua escrita, val hoxe tanto como quentarse demáis. Un pan «arrequentado» é un pan que levantóu a coda e tamén 
que se chamuscóu. Non lle valéu á esta palabra figurar nunha oración que aínda se di en algunhas comarcas no momento de enfornar:

Diolo arrequente no forno e nos agros e día gozo del á vivos e finados.

Pedir que Diolo queime e lle faga levantar a coda é un contrasentido. Con todo eso, é o sinificado que lle dan. «Arrequentaron os bolos de atrás», quere decir que se chamuscaron, que os apretóu a calor.

Neste caso, anque non se producíu cambio fonético, a mutación semántica é de orixen fonético. Aquí estudiarémolos cambios de sinificación totalmente independentes da forma das palabras, que son case tan numerosos.

Trátase dos que veñen condicionados e sometidos á realidades sicolóxicas e sociales. O normal é reducir estes cambios a categorías ou «figuras». Lenguaxe figurado: metáforas ou catacresis, sinédoques, metonimias, etc., esplicando dentro de cada unha destas categorías os diferentes semantemas. Hoxe téndese máis ben á analizar as realidades sicolóxicas e as influencias sociales que condicionan os cambios.

Aquí usaremos dos dous métodos, hasta onde poidamos, pois é escusado decir que, sobre tratarse de feitos sutiles que non é doado analizar, nos que caben, ás veces, tódalas interpretaciós, carecemos de toda clas de materiales de traballo que nos poidan servir de guía.

\section{Metáforas}

Desde un punto de vista tradicional, os cambios semánticos independentes dos fonéticos redúcense a tropos e figuras. Os tropos trasladan o sinificado dunha palabra á outra. As figuras esténden e acurtan o sinificado dunha palabra. Os trópos céntranse na metáfora ou catacresis e as figuras na sinédoque e na metonimia.

A metáfora nace da imaxe nova que se forma dunha cousa por comparación con outra. Cando un menciñeiro reconocéu que o mal que impedía comer a un animal proviña dunha clas de bultiños de carne que se lle formaron ó carón das moas pensóu ó velos nunha faba. Eran semellantes na forma. Aqueles bultos eran 
coma fabas. A imaxe dos bultos quedóu feita dentro do molde da imaxe dunha faba. E, como o nome de bultos non era preciso, impúxose o nome de «faba» pra desinalos.

O menciñeiro fixo unha metáfora sin sabelo, que é como salen ben.

Non sempre ocurre así. As cousas poden ter un nome preciso. Pero este nome chega á gastarse como se gasta todo. Son entón palabras luídas e afumadas, das que case non se sabe o que sinifican. Nestes casos a metáfora ven á renovalas.

Contra o que se pensa, non é este un procedimento de orixe literario, senón fundamentalmente popular e propio das lenguas pobres e primitivas.

As lenguas de hoxe, ricas en nomes abstractos, nun comenzo non tiveron outro recurso pra facerse con eles que trasladar a sinificación abstracta á nomes de cousas concretas. Verbos abstractos como «trasladar», "comprender», «cavilar», non sinificaron noutro tempo máis que «levar dun lado pra outro», «coller entre os brazos» e «traballar coa cabeza».

As metáforas de unha lengua son infinitas, e poden ser máis ou menos vivas según o uso que leven e según se sintan máis ou menos. Nestes versos de Rosalía:
Mais ve que o meu corazón
é unha rosa de cen follas.
Quitas unha, quitas dúas
penas lle quedan dabonda.
O corazón me arrincaras
desque as arrincaras todas ${ }^{18}$.

son de orixe metafórico, dentro do gallego, «rosa de cen follas», «penas», «o corazón me arrincaras» e «desque as arrincaras todas» (as follas). Pero non todas teñen o mismo grado de novedá na lengua. Unha «rosa de cen follas», co valor do "corazón», é unha metáfora recén estrenada; "pena», polo contrario, xa non

\footnotetext{
18 [Rosalía de CASTRO, «Follas Novas» I 17, en Rosalía de CASTRO, Obras Completas. Recopilación y estudio biobibliográfico Rosalia de Castro o el dolor de vivir por Victoriano García Martín (Madrid 1972) 422: «Mais vé qu’o meu corazón / é un-ha rosa de cen follas, / y é cada folla un-ha pena / que vive apegada n'outra. /Quitas un-ha, quitas duas, / penas me quedan de abonda: hoxe dez, mañan corenta, / desfolla que te desfolla... / ¡O corazón m’arricaras / des qu’as arrincaras todas!».
} 
se sinte como tal á non ser que se relacione con «pena», pedra de gran tamaño, que nos oprime, por homonimia. «Arrincar o corazón» é relativamente nova frente a «arrincar as follas», onde xa está máis gastado o verbo «arrincar», que orixinariamente sinifica «sacar da terra as raíces dunha planta».

Esta é a maior debilidá da metáfora: vai á vella de seguida.

As metáforas que primeiro se gastan son as dos compostos, desprendidos das formas simples que lles deron orixe. «Reloucar» garda pouco de común con «louco», sustituído na lengua común por «tolo»e «revoldaina», revolta de vento, reña, alboroto, non garda nada con «revuldar», desaparecido no seu valor orixinario de «revoar». En xogos de palabras coma este:

\section{Unha pega revoldá puxo un ovo na quintá puxo un e revuldóu, puxo dous e revuldóu puxo vinte e reventóu.}

non se sinte pra nada o resultado de «revuldar».

Nos derivados gástanse tamén axiña as metáforas ó especializarse. $\mathrm{O}$ «carreiro» en xeneral, pero sobre todo o «carreiro do pelo» e o «carreiro das costas» non son precisamente camiños por onde ande o carro. "Ferradura» desprendeuse tanto de «ferro" que os paisanos falan de «ferraduras de coiro" pra os bois. E deste xeito, ó perder o entronque co seu orixe, os derivados máis ou menos metafóricos chegan á sinificar o contrario do que sinificaban, como vemos en "carreiro», que é precisamente un camiño por onde non pasa o carro.

As condiciós mellores de vida pra as metáforas son os períodos de vulgarismo. $\mathrm{Na}$ lengua dos Cancioneiros e na literatura medieval toda, apenas si encontramos outras metáforas que as moi gastadas xa. Os escritores do XIX fixeron máis uso dela polas tendencias románticas ou populares que seguiron e nas que a imaxe solecía por igual.

Nos nosos días síntese un gusto especial en chamar ás cousas por nomes técnicos. Prefírese decir que se teñen as enginas á decir as papeiras ou os orellós. Vivimos nun período de cultismo, de precisión técnica dos que se repiten moitos na historia. O latín vulgar viña cargado de tropos e figuras, polo que o gallego é 
no seu orixen unha lengua de imaxes. Hoxe sigue actuando tamén o sino popular que lle asiste e que a sigue renovando por este método.

Tódolos tecnicismos que se van introducindo non son nada ó lado das metáforas que nacen na vida de cada día. Un paisano gallego apenas si chama nunca ás partes do corpo polo seu nome. A «cabeza» é o «casco», a «chaminea», a «meloura», a «mola», o «tellado», o «lousado», o «alboio», a «cachimonia». $\mathrm{O}$ «peito» é o «cárcabo», o «trobo», a «caixa», o «forno». As «maus» son as "poutas», as «gadoupas», as "gateñas», as «unllas", os «ganchos», as «cinco».

A razón desta multiplicación de sinificados está en que unha palabra metafórica non se apoia máis que na semellanza de sinificado que ten co sinificado da sustituída. Debido á esto, pode ser desbancada por outra que teña sinificado sinónimo con ela, e ésta, por outra nas mismas condiciós, e así hasta que cheguemos ó conto de nunca acabar.

Desde que «tocar», na espresión «vai tocar», sinificóu «irse de paseo», non hai istrumento conocido que non se lle puxese de complemento: «vai tocar $o$ violo, a gaita, o pandeiro, a pandeireta, o pindinn»; "vai tocar á morto, á santos».

As metáforas poden clasificarse polo sentido que nos dá a sensación e de onde arrinca a imaxe. Refírense ó gusto as que atopamos en «amargoulle, soupolle mal» (unha reprensión); «botoullas salgadas», que sinifica «cantoullas claras»; «viña acedo» (con mala cara).

Son olfativas «chéirame á can» (desconfío); «has de ulilo» (non o verás); «óleme que é certo».

Táctiles e musculares hai moitas: "É un pe de muíno», "díxollas fervendo», «esas van quentes», «van fervendo», «heite quentar, sacudir, cardar»; «non lle quedóu frío».

As auditivas non parece que abunden: «Oubeaba como os cas», «déixao ladrar», «ó que cochos busca, as carballeiras lle roncan».

A maioría son, sin duda, visuales: a "testa», que recibimos do latín vulgar e que sinificaba no seu orixe un pucheiro de barro; "cristas» e "galos», que son certas clases de plantas, nas que abundan moito os nomes metafóricos. Temos «lenguas de ovella» e «de vaca», "pe de páxaro», «pucho de sapo», "pan de cobra» e moitas máis.

Nas trasposiciós metafóricas non se mira á que as sensaciós comparadas señan do mismo tipo. Noriega Varela decía da gaseosa, que chamaban "graciosa» no 
seu tempo, que «sabe á puntas de agullas» e que «é rosmona», sustituíndo así unha imaxe gustativa por dúas que o non son: táctil a primeira e auditiva a segunda. (Esta última partía dun suposto falso: supoñía que a gaseosa era alcólica. «Rosmón» é un adxetivo figurado que se refire ó viño de moitos grados).

A lengua popular sabe tamén deste secreto. Decir dunha persona que «fala mouro» quere decir que blasfema. Un pano ou unha cousa «amorosa» val tanto como «suave».

Desde outro punto de vista, a trasposición pode facerse entre palabras da misma categoría gramatical ou de distinta. Trasportar a sinificación de «folla» de libro á «folla» de labranza é moi normal; pero hai casos en que un adxetivo se trasporta directamente á sinificación dun sustantivo, sin necesidá de ir antes xuntos, como ocurría nos casos de elisió («chousa», de villa-clausa). As palabras «zucio», «vello», "patanexo», con que se conoce ó demo, son adxetivos que nunca o determinaron como clausa determina á villa.

O nome abstracto «cinestro=sinestro» e outros moitos abstractos, débense á este tipo de trasposiciós.

Si pensamos nas cousas que provocaron as metáforas, veremos que se trata das que caracterizan a época e o medio en que se vive, os oficios e as profesiós. Hai unhas que son de máis vida que outras. As que parten de invenciós de moda (non estóu en onda, non carburo) duran pouco tempo, mentras que as tomadas da naturaleza, do tempo, da vida das plantas e dos animás, poden durar siglos.

Según lemos na "Compostelana», chamábase "gato» un istrumento de guerra que trougo de Génova Gelmirez pra pinzar o castillo de Lobeira en Vilagarcía. $\mathrm{O}$ istrumento aquel perdeuse, pero a palabra "gato» sigue aínda sinificando outros istrumentos parecidos.

En gallego tómanse, sobre todo, do reino vexetal e animal, dos aveños de labranza e particularmente das laborías. «Vaca loura», "cabalo do demo», «cabra do monte» (moza lixeira), «bubela» (moza graciosa), "pomba» (nena inocente), «axugar» (aparexar), «soltar», «apiegar», «acadarmar» (traer á raia unha persona), «arar dreito» (complir coa xusticia), «salir do rego» (faltar ó deber), son unha pequena mostra. 


\section{Metonimia e sinédoque}

O mismo que a metáfora, a metonimia e a sinédoque veñen provocadas por unha asociación de imaxes de cousas. O que as diferencia é que a asociación metafórica arrinca da semellanza das imaxes e a asociación destas figuras, da contigüidá. Ésta contigüidá de duas imaxes nace de que as cousas non se representan isladas, senón en contacto unhas con outras, en mutua dependencia de lugar, tempo, causa, orixe, posesión, acción, etc.

Estas figuras non crean novas formas, pero, como fai a elisión, danlle brevedá, á costa de cargar de sinificados unha palabra.

Tradicionalmente estudiábanse os casos de metonimia e sinédoque por categorías ideolóxicas: continente por contenido e ó revés, o todo pola parte e ó revés, a causa polo efecto, etc. Pero parece que nos achegamos máis á vida da lengua si amoreámolos feitos ó redor das causas sicolóxicas e sociales que os producen ou condicionan.

Tódalas categorías ideolóxicas en que as figuras se dividían se reducen á tres feitos fundamentales. Hai palabras que fan entrar na súa sinificación sinificados que antes non tiñan. Chamarémoslle a este feito «estensión». Outras fan ó revés: quédanse cun sinificado e perden os demáis, ou acurtan o único que tiñan á casos determinados. Podemos chamar a esto «restrinción». Outras, por fin, que desinan partes dun todo, poden pasar de sinificar unha á sinificar a veciña. A este fenómeno chamarémoslle «dislocación».

As restrinciós e estensiós de sinificado dependen de que as palabras sallan da lengua común e entren nunha lengua técnica ou, ó reves, que sallan da técnica e que entren na común. A dislocación é un fenómeno máis complexo que esplicaremos no seu lugar.

O fondo orixinario do gallego estaba formado por moitas restrinciós. Acordémonos da palabra "paisano», que entróu cun sentido restrinxido de tipo relixioso.

A liturxia da Iglesia tivo que buscar tecnicismos na lengua común. Entre outros moitos atopóu nela «bispo» (vixilante), «presbítero» (o mais vello), «iglesia» (asamblea). Usóu estas palabras pra outros tantos oficios ou sinificados restrinxidos, e non lles fixo falla á estas palabras outra cousa pra salir da lengua común e perder unha parte do seu sinificado. 
Os xermanos, pola súa parte, como os visigodos e outras xentes coas que tivemos relación, si deixaron algunha palabra, foi de valor restrictivo, de oficio.

Lengua por outra parte de labradores e mariñeiros, menestrales, señores cazadores e guerreiros e monxes agricultores, o gallego é na súa cerna intima unha lengua de base restrictiva.

Palabras da lengua común de Roma, como laborare, moi rica en sinificados, pasóu ó gallego no sentido restrinxido, menestral e labrego de labrar un pano, unha terra, unha leira. De calquer xeito, non faltan estensiós de sinificado. O desenvolvemento desta misma vida de oficio tivo que botar mau delas por forza.

A dislocación, como antes dixemos, ten lugar nos casos en que un todo ten distintos nomes pra cada unha das partes: o corpo humano ou dos animás, algús aveños de labranza, o forno, a cuciña, etc. Consiste en pasar unha palabra de sinificar unha destas partes á sinificar a inmediata, como rebasando. Este procedimento é o que produce os resultados máis desconcertantes pra cantos non teñen unha idea máis ou menos clara do desenvolvemento da lengua. Cuveiro Piñol e o mismo Valladares tropezaron con este incomenente. Non pode moita xente comprender que o mismo aveño se chame, nun sitio, «raño», noutro, «sacho», e noutro, "gadaño». E, con todo, é un fenómeno que se dá en tódalas lenguas máis ou menos. Non se trata de metáfora, restrinción nin estensión. É nada máis que un esbarruximento dos nomes dun conxunto no que os sistemas son moi fráxiles e están sempre á facerse e desfacerse.

A palabra «coxa» sinificóu primeiro as nádegas e por imprecisión en señalar onde éstas rematan, pasóu á sinificar a parte que sigue pra baixo e que na lengua culta chamaríamos «muslo». Si hoxe preguntáramos a vinte paisanos cal é a «coxa», o «corvaxón», o "chambrón», teríamos tres ou catro variantes. Hai quen baixaría as «coxas» ás "polpas», quen as deixaría no medio, no «corvaxón». Entón subiría éste ós «muslos» ou desfaríase del e chamaría ós «muslos» os «chambrós». Sucedería en algús casos que os «muslos» se chamasen «coxas» polo lado de fora e «corvaxós» polo lado de dentro ou ó revés. Calquera combinación pode esperarse.

En menor grado pasoulle o mismo á palabra «boca», que primeiro sinificóu as «mazás da cara», que é como lles chaman en algús sitios ás «meixelas», alternando con «lados da cara», «beridas», "papos», «fazulas», etc. 
Nos aveños de labranza e nos traxes son máis compricádolos feitos porque a súa mecánica é un pouco distinta. Cun aveño ou cunha prenda de vestir ven un nome. Esta prenda ou aveño desparece e o que ven a sustituílo pode levar o nome do que caducóu, nus sitios, e, noutros, un nome novo ou o nome de outro aveño parecido. Si á estes feitos superpoñémola dislocación darémonos conta de que o mismo nome pode sinificar tódolos aveños que entren nunha laboría, según os lugares e os tempos.

«Capa», no siglo VI, sinificóu unha clas de gorra. Na Edá Media un manto. Do siglo XVI ó XVIII unha capa longa. Do XIX en diante, máis curta. Hoxe é unha prenda de muller máis ben. Si temos en conta as sinificaciós metafóricas, a historia desta palabra podía encher un bon volume, xogando na maior parte dos casos á este xogo da dislocación, e o mismo os seus derivados «capote», «capucha» e «capillo».

Despóis do dislocamento dos nomes sobre cousas distintas que veñen unhas despóis de outras no espacio e no tempo, é onde podemos poñer as figuras de continente por contenido, causa por efecto, todo por parte, etc. Hoxe moita xente fala das «arañas» e das «teas de araña», pero hai moita tamén que chama «arañas» ás «teas de araña». Pra os nenos da aldea o «correo» é un tren ou ben un auto que lle chamán así. Pra algús é aínda o seu primeiro dono, o home que leva as cartas. "Pasóu cedo o correo», din referíndose ó peatón. Claro está que non pensan si corre ou non. Pra a gran xeneralidá, con todo, correo é a correspondencia que recibe.

As relaciós abstractas que se poden criar entre dúas cousas son infinitas. Danse contaminaciós entre sustantivos. "Celibato» valéu tanto como viudo noutro tempo e sinificóu estado de perfeución.

Unha destas relaciós é a do produtor (árbore, fabricante ou pais) e o produto, que leva, en moitos casos, o nome de aquéles. «Plátano», "pimento», «tomate», «sandía», "pataca», etc. confunden o nome da planta e o do fruto.

O istrumento tamén pode desinar o produto. Un «fuso de la», un «óleo», unha «acuarela». 
Forman un grupo aparte os abstractos que se fan concretos, como «dilixencia «, convertido nun tipo de carro, «hábito», en traxe de monxa ou de frade; «labor», en renovo de viña. Estes nomes citados gardan a súa sinificación abstracta, outros non, como «tenza», «morada».

As personas, por un fenómeno parecido á éste, levan un alcume feito co nome dunha prenda ou dunha parte do corpo: o «barbas», o «chaquetas», o «zamarra», o «boinas», o "cachavo», o "pernas».

Un istrumento tamén pode dar nome ó que o usa: o «ganzúa», o «palanqueta», no argot dos moinantes; a "primeira escopeta de Galicia», na dos deportes.

Unha cousa pode dar nome á tódalas que a rodean ou están dentro dela. «Levantouse a mesa» quere decir que tódolos convidados se ergueron. «Ten boa eira", quere espresar que ten boas medas de pan nela. En Galicia chamamos «afiadores» ós de Ourense, por unhas cantas ducias que hai deles no país.

Unha palabra moi repetida na boca dunha persona acaba por desinala: ós nosos emigrados chamóuselles "ches», ós mexicanos, «manitos», e ós mouros de Africa «Mohamés». Este procedimento pode estenderse ás cousas de que son donos esas personas. Ós novos autos de moito precio deúselles o nome de «haigas» porque os donos, que non tiveron tempo de adeprender á falar mellor, ou que supón a xente que o non tiveron, repetían esta palabra.

Por fin, facemos uso dos nomes abstractos da función para desinar ó que a desempeña: «un guardia», "un guía», «a vixilancia de noite», «a ronda».

Debemos poñer aparte os nomes propios que se fán comús, porque supoñen unha estensión do sinificado, frente ós fenómenos que levamos anazados, que eran de dislocación ou restrinción.

Algús nomes de países deron nomes de plantas. "Abellana» leva o nome dunha ciudá antiga, "péxego», o de Persia, «berlina» o de Berlín e xa sabemos todos dos numerosos nomes propios que se fixeron comús pra desinar produtos, sobre todo vinícolas. A palabra «buxía» entróu moi axiña en Galicia. As buxías de entón, coma as de agora, eran veliñas moi pequenas ó lado das «candeas» que as mozas dos Cancioneiros levaban ós santos. Cunha delas amenazaba unha destas mozas ó santo da súa devoción, si non lle traía o «seu lume e seu ben». 
Os nomes xentilicios deron adxetivos calificativos. Os francos da Edá Media deixáronnos o adxetivo «franco», que pasóu a sinificar «liberal» e os do XIX, «franchute», que convertido en «farabute» e «faraute» sinifica home lixeiro, presumido e pouco de fiar. «Xitano», de Exiuto, e «asesino» procede do nome dunha secta de Asiria.

Algús nomes de persona, real ou non, sirven pra desinar cousas, coma «damaxuana», «pedro», «pepona», «queitana», «roquete». Algunha destas trasposiciós son de orixen litúrxico, como un «lázaro», un «nazareno», unha «madanela», que se aplican á personas.

A literatura contemporánea non pode prescindir de trasposiciós de orixe literario, como «sosias», «tartufo», «anfitrión», referidas tamén á personas.

Algo distinto é a creación de nomes simbólicos, como «Santa Lilaila» e «San Bode», Santa Lilaila é o símbolo do embuste e da patraña e San Bode o do egoísmo e da ambición. 


\section{A LENGUA, ESPELLO DA CULTURA E DA SENSIBILIDÁ}

\section{1. [O ELEMENTO INTELECTUAL]}

O gallego, por popular, é unha lengua espontánea e impulsiva. É, sí, unha lengua de xentes ouservadoras e afanosas de precisar matices e de especializar palabras e sinificados. Como lengua de labradores, chegóu ás mais finas variantes pra desinar os animás, según o seu color, edá condiciós, oficios e destino. Unha ovella pode ser unha "aña», unha «andosca», unha «entrega». Os dentes dunha vaca divídense en dous «canteiros», dúas «pas», dous «medios» e dous «cabeiros». De igual maneira é rico en vocabulario preciso dos distintos terreos e laborías. As terras poden ser «fondas», «lixeiras», «peneleiras», «terraxís», «barrentas», «illoentas».

Únase á esto o sin fin de nomes técnicos de cerrumes, entradas, salidas, airas, casas, aveños, camiños. Sólo en camiños, aparte carreteras e vías, hai todos estes nomes: «camin̄o» (desinación común), «vereda» (dirección), «camiño real», «carreiro», «carreira», «camiño de ferradura», «camiño de cabras», «travesío», «corredoira», «atallo», «rodeo»...

Sobre outros aspectos, como é natural, falta toda precisión. A paleta de colores é un cempés. «Rubio» e «roxo» aparecen confundidos. En «iAi roxiña, roxiña do pelo», «roxiña» está claro que indica unha nena rubia. Pero unha vaca «roxa» é a que ten pelos «brancos». Pra que seña maior a confusión «teixo» e «roán» sitúanse entre roxo e rubio tamén. A vaca «teixa» e o cabalo «roán» teñen un color entre «rubio» e «roxo». Pero o cabalo do color da vaca «teixa» chamaríase «castaño». Non hai cabalos «roxos»: son «ruzos» ou «pedreses». E unha vaca gris ou unha persona «canosa» son «roxas» e non «pedresas». «Ruzo» é común. Basta esto pra ver que o gallego non ten unha paleta de colores, e a razón deso está en que non chegóu á imaxe abstracta deles, como non chegóu á descriminación de moitas especies. Fora de unhas cantas plantas útiles ou medicinales, hai a misma inseguridá que en todo o que non seña da lengua dos oficios da terra e do mar. 
O que dá precisión e rigor ás lenguas son os estudios centíficos e técnicos, o desenvolvemento literario e filosófico, que trai consigo esquemas abstractos, a formación de grupos sociales escollidos e soldados fortemente, naturalmente, ó resto da sociedá, á esixencia espontánea nestes grupos de buscar espresiós precisas pra a orixinalidá da súa maneira de pensar e de sentir. Sin todo esto, o gallego non pode ser mais do que é.

A lengua escrita da Edá Media desenvolvéu algunhas formas abstractas. Pero, si repasamos os vocabularios antigos, veremos que son precisamente as que están mortas. Nunha sola cantiga de Esteban da Guardia, a 924 do C.V., aparecen estes abstractos, demáis por certo se miramos á lirica: «serviços», "crença», «coita», «sabença», «servente», «frontar», «entendente», «encoberta», «razón», «creente», "peage», «mensage» e «contenente». Si descontamos «servicios» e "crencia», dúas restauraciós da lengua oficial, tódolos demáis abstractos se perderon ou perderon a súa condición de tales, como «encoberta» que volvéu a ser adxetivo.

Os escritores do XIX pra acó, sobre todo os contemporáneos, levaron ós seus escritos, como produto da reflesión que toda lengua escrita impón, un bon número de abstractos, formados de moi distinta maneira e algunhas veces por métodos caducados. Estes abstractos son os que se lles botan en cara, case sempre sin razón, como deturpaciós da lengua. Os ataques parten de xentes semicultas e apóianse sempre en razós extralingüísticas, por inorancia do papel que o escritor representóu sempre no desenvolvemento das lenguas.

O peor de todo, é que os que falan gallego non len nada nesta lengua, e deste xeito a lengua escrita non fecunda a lengua viva, e pérdese de día en día o contacto entre as dúas, con grave perxuício pra ambas. Un día calquera atoparémonos con dúas lenguas, o que non sería novo na historia tampouco.

Esto polo que se refire ó desenvolvemento intelectual, como renovador e ordenador da lengua.

\section{O ELEMENTO AFECTIVO}

A acción dos fenómenos afectivos que se dan nos individos e nas sociedades non son menos importantes que cada un dos que levamos estudiados. A acción da 
afectividá sobre o vocabulario obra en dous sentidos. Por un lado, tende á desgastala e luíla e, por outro, á reforzala e darlle resalto, como vimos que sucedía ca metáfora e cas figuras, espresiós directas sempre da afectividá.

O desvaimento semántico dunha palabra -quintá, revoldá- a creación de metáforas novas e o seu progresivo desgaste son fenómenos sicolóxicos afectivos que parten do individo e do medio social.

"Causa», en latín, sinificaba proceso xudicial entre outras moitas cousas. No siglo X xa non sinificaba apenas ningunha. Nun documento dese tempo cóntase que lle deron un cabalo alfaraz á un rei de León porque era gustante de causas bonas. Desde entón causa pasa á ser cousa, desvaída totalmente no seu sinificado. Cando o desenvolvemento intelectual e afectivo precisóu dela, tivo que ir á buscala de novo ó latín de Cicerón, que con tantos matices a usara.

Pasóu o contrario con res, e pola misma razón. Esta palabra era un comodín na lengua clásica, algo así como o «aquel» noso. Pero a lengua labrega, concentrando a súa sinificación dispersa no sentido da súa afectividá, deulle a sinificación de «animal doméstico».

Esta necesidá de renovación da lengua, como produto da nosa afectividá, vese ben nos diarios, que teñen que falar tódolos días das mismas cousas. O periodista cánsase axiña dun título. "Morte», «defunción», «óbito», «falecemento», «necroloxía», «perda que sentimos», «baixa», son os títulos con que se dá a noticia de que alguén morréu, según os tempos e outras moitas circustancias, todas de tipo afectivo. Os temporales de tal ou cal comarca fanse, ó ano que sigue, «tempestades», ó outro "ciclós», hasta rematar en "tornados» nos días que vivimos. No ano 1930 todo era «terrible». Antes fora xa «fenomenal» e "colosal». Despóis convertiuse en «fantástico» e hoxe dise «de medo», según as preferencias da moda, que veñen espresadas polos anuncios de cine que a xente chama eslogans.

A técnica que se usa pra renovar unha palabra gastada varía moito. Pode consistir, coma nos casos que vimos, en sustituíla por outra. En apoñerlle un adxetivo ou un adverbio, que se renovan de tempo en tempo, como vimos tamén, ou en volvela á mai por regresión. Poden tamén usarse tódolos procedimentos que xa espuxemos de elisiós e abreviaciós. O que é moi delicado é determinar en cada caso cal é a forza afectiva que actúa. Vese ben como «mangar» pasa a sinificar «roubar» por contaminación con «mangante». Pero xa non está 
tan claro por qué, na lengua dos «mangantes», «traballar» sinifica «roubar». É de tipo afectivo, sin duda, a espresión. Pero ¿qué afección a provoca?. ¿Ironía, desprecio ou axe do traballo, amoralidá da profesión?.

\section{Algús tipos xenerales de afectividá}

As formas principales de afectividá son as que se manifestan nas espresiós de cariño, boa educación e distintas clases de eufemismo, nas que se poden esconder, desde prexuicios de clase, hasta os máis altos refinamentos dunha sociedá escollida e traballada por siglos de riqueza, mando e selección familiar.

Desde esta altura xa podemos medir á priori as calidades da nosa lengua, frente ás grandes lenguas cortesanas e burguesas. O que se atope nela de alto valor, que o hai, é, nin máis nin menos, un milagre.

É moi viva a actuación da afectividá cariñosa, sobre todo de mais á fillos. O lenguaxe amoroso da mai, espresado en cantares populares, chega á deformar o vocabulario hasta o infinito, e logra, sin duda, espresiós de gran forza. As palabras veñen traspostas de todo canto rodea á unha mai labrega; de canto é pequeno, alegre, gracioso e inocente no pequeniño mundo dunha aldea, con días e noites, estrelas e paxariños. Aquí campea o xenio individual. $\mathrm{O}$ amor filial canalízase mellor pola vía relixiosa, e ten como obxeto principal á Nosa Señora, símbolo da Maternidá natural máis limpa.

Esta misma afectividá materno-filial é totalmente distinta cando non se dirixe ós obxetos. Cando é narrativa. Hai entón unha especie de atenuación que busca formas de escarnio. Pra falar do seu fillo con outro as mais usan das palabras "enredo», «cria», "cruz», «bazuncho» e outros despectivos, e os fillos, pra referirse as máis, usan as de «vella», «rosmona». Este tipo de reacción afectiva é vello e interesante, pero non podemos deternos á esplicalo.

O lenguaxe amoroso dos enamorados conoce as dúas pendentes tamén, como pode verse na nosa rica colección de cantares eróticos. A lírica medieval, con ser amorosa na maior parte, non abunda en creaciós deste tipo. Despóis de «miña señor», «meu lume» e «meu ben» queda pouco que buscar.

En canto ás fórmulas de boa educación e respeto nótase unha alta estima da muller, ó revés do que pasa noutras lenguas. Consérvase moito tempo «dona», que hasta certo punto non desaparecéu, no primitivo sentido de domina. Inda 
que é cun tono de atenuación retranqueiro que o home do campo refírese á muller chamándolle dona. Vese que é unha espresión gastada. «Dono» sinificóu, hai moito, propietario, e esta sinificación deslustróu a de «dona».

Do francés chegounos «dama» e «mesía», que duraron tan pouco tempo, e que quizaves fosen localismos vilegos. "Dama» úsase aínda pra sinificar «señora», pero refírese ó porte e non é fórmula de respeto.

$\mathrm{Na}$ lengua de hoxe a fórmula de respeto é o «señor» e a «señora», nacidas de senior, o máis vello, que xa no Baixo Imperio tomóu este sinificado, impedindo que dominus, degradado polos pequenos propietarios, seguise co que tiña. O feito de chegar á depender a formula de respeto femenina da fórmula masculina é un sino do cambio de afectividá que se operóu en Galicia, despóis que as «donas» dos centos de conventos de Galicia pasaron á Santiago pra non ser nada máis que «monxiñas benitas».

Por debaixo de «señor» e «señora», que se estenden sin artículo como complemento de calquer «sí» ou «non» que se día á unha persona de respeto entre xente ben falada (si, señor; non, señor), veñen «amo» e «ama», «señor amo», «señora ama», palabras nacidas dun vulgarismo semellante ó que deu «mamá». Nótese como aquí tamén trunfóu a fórmula femenina.

E ésta a formula de respeto con que os «caseiros» se dirixen ós donos das terras, inda que señan grandes señores, distinguíndose así dos criados. Fora dos caseiros ou colonos, que nunca se chaman «criados», chámanse «criados» e chaman «amos» ós seus superiores os que levan vacas arrendadas, os obreiros e xentes de paso ós donos da casa, os menestrales e xentes de oficio ós seus maestros.

$\mathrm{O}$ uso destas fórmulas estaba fai algún tempo regulada por normas máis estrictas que as de hoxe. Tódalas espresiós de respeto (pai, mai, tio, primo e irmáu, amo, ama, etc.) levaban diante a palabra «señor» ou «señora»: «Señor tío», «señora madre», «señora ama». Nin Pedro Madruga se escusaba. Unha famosa carta del comenza así: «Señor hermano». E unha cancionciña de nenos, que aínda hoxe se repite, conserva esta fórmula pra mai:

serra compadre

serra comadre,

nas madeiriñas

de señora madre. 
«Señor» e «señora», cumes de cortesía, cando van solos, levan diante o artículo. «O señor», «a señora». E non sólo pra desinar os grandes señores, senón tamén pra referirse á un desconocido. «O señor ¿qué desea?». «Con permiso do señor».

A moda das criadas das vilas, quizaves imposta polas amas, fai que en moitos lugares se chamen «señoritos» e «señoritas» ós que antes se chamaban «señores» e «señoras» ou «amos» e «amas», si non chegaban á unha nobleza dada.

Nas vilas é hoxe normal, pero os paisanos non aceptan esta denominación máis que pra os fillos dos señores.

Cando un se intresa pola salú da muller diante o home ou ó revés, así como pola dos fillos, debe usar as palabras «amo», «patrón», «ama», «dona»e «nenos» ou «mozos», según a edá. Decir «señor» ou «señora» permítese, pero é irónico e confianzudo. As palabras «home», «muller» e «fillos» son vulgares.

\section{O eufemismo}

Consiste este procedimento en aludir de lonxe á unha cousa que se teme, que se adora, que se desea pra un solo, que repuna. O misterio de gran parte da poesía medieval está en esconder o nome da que se ama. Hai lenguas que contan con estudios especiales pra este fenómeno.

Houbo nas lenguas antigas nomes tabús, que non se podían lumbrar. En castellano está prohibida pra moita xente a palabra "culebra» e, en gallego, hai algunhas palabras e espresiós desfiguradas por temor relixioso ou convenciós sociales. "Diola», «rediola», «diez», «briós», que son desfiguraciós da palabra Dios; «demoro», «diaño», «diantre», «deño», «demontre», que o son de demo e demoño; «búzara» e «búlzara», de bulda; "xuncras», de Xudas; «aña» (heiche quentar a aña) de alma; "condenido», «condenícaro», «condanácaro», «conxanado» e "condanaxado», de condenado, e "conxanar» e "condanaxar», de condenar.

En vez de desfigurar as palabras, trócanse ás veces por outras. $\mathrm{Na}$ lengua dos "xurafaces» (os que xuraban pala Faz), «Sevilla», "Soria», «Santoña» e outros nomes fan as veces dos de algún santo. Nas espresiós de «léveme o crego», «léveme o Pepe», o «crego» e «Pepe» están no canto da palabra demo. «Voto a Chicho Valillo!», que recolle Valladares, esconde a palabra Cristo con algún dos atributos máis altos. 
Noutras espresiós, a trasposición é nada máis que dun adxetivo ou adverbio. "Manda $o$ de arriba», "cómame o cuzo», "léveme o vello», que pode desfigurarse en «vedro», son trasposiciós de Dios e demo.

Os eufemismos relativos á cousas que repuñan varían moito cos tempos e lugares e, sobre todo, co refinamento da sociedá. Cando leamos a Frai Luis debemos pensar que era un escritor refinado, pero que os tempos non daban máis de sí. Outra cousa é o escritor desenfadado, do que falaremos logo.

Hai que reconocer, neste punto, que o gallego é unha lengua espontánea, falta da lima dunha sociedá cultivada. Pero non é tanto como pensa moita xente, engañados polas normas dunha concencia lingüística estraña ó gallego.

O eufemismo ten tódolos recursos de outras formas afectivas para actuar sobre a lengua. Recurre á metáforas, elisiós e cantos medios vimos pra eludir a espresión brutal. Recórdense os nomes de "pieza», «retrete», «escusado», "xardín», «W.C.», que parece o máis inodoro de todos. Os nomes estranxeiros teñen esta virtú eufemística.

A alteración das creaciós eufemísticas é grande debido á que non tardan en facerse outras asociaciós de ideas que fan tan vil a nova espresión como a primeira. «Sífilis» chegóu á ser máis repunante que «gálico».

As categorías dos eufemismos son moitas. Afectan, en primeiro lugar, ós nomes de algunhas partes do corpo, á certas funciós naturales, ós nomes de certos animales e enfermedades, estado e posturas dunha persona, edá, profesión, etc. Os que falan castellano en Galicia estenden o número destas categorías ós nomes de todo canto sinifica vida tradicional aldeana, de calquer tipo, resistíndose á ver ningunha nobleza neles.

A lengua labrega non sinte a acción do eufemismo sobre ningún nome de animal, se non é quizaves o "godallo». «Porco» e «cocho» están algo contaminados da sinificación do adxetivo. O chamarlles «os da vista baixa» é unha transposición humorística, independente do eufemismo.

$\mathrm{Na}$ lengua vilega, con todo, polo que xa dixemos, téndense á eliminar os dous nomes pra dar lugar á «cerdo» $\mathrm{Ou}$ «serdo», según as comarcas.

O macho cabrío deixóu o nome que lle correspondía, que pasóu á ser unha bocalada, polo de «castrón», que empeza á ser de mal gusto entre os que teñen concencia desta forma en castellano. 
Nas enfermedades evítase nombrar certos tecnicismos conocidos, como «tísico», «sifilítico», «tuberculoso». Dise que «está do peito», «que ten unha enfermedá mala».

Noutros casos, ó reves, faise uso dos tecnicismos, por influxo dos mismos médicos, que tratan de dar carácter leve ós casos: unha «laringites», unha «faringites». O normal é que non se pronuncien de boa gana os tecnicismos graves: o «cru», a «diteria», «sarcomas», «fibromas», etc., trátase de evitalos, así como «pleuras». Prefiren nestes casos usar os nomes vellos, «costados», «resfriados», «enginas». A «quebradura» nunca foi de bon gusto lumbrala. Decíase «dado dunha engua». Hoxe téndese á chamarlle «hernia».

A idea da morte leva consigo eufemismos de orixe relixioso. Acerca das personas que se estiman hai un vocabulario especial. Si se dí que «morreu fulano de tal», dunha parroquia de lonxe, co que non había especiales relaciós, tratándose dun parente dise que «deu a alma á Dios», «que xa está con Dios». Estas espresiós poden nacer das observaciós do último trance: «espiróu», «zarróu» ou "pechóu os ollos». «Vai aló», "foise», "xa non fai mal á ninguén», «xa se libróu de traballos». Pra señalar o cadáver dise o «difunto» ou a «difunta» e tamén a «caixa»: "¿quén vai levala caixa?». "Puxérona caixa diante a iglesia». «Levárona caixa os sobriños». Pra espresar o acto do enterramento, din «darlle terra».

Pra referirse en calquer momento á un morto, úsase a perífrasis de «o que faltóu da casa», "quen come a terra».

O estado de bébedo ten nomes moi cambiantes, us de escarnio e outros eufemísticos: entre os primeiros están "peneque», «bon», «coma a uva» e, entre os segundos, «alegre», «contento», «cunha copiña». A inebriación ${ }^{19}$ ten nomes sin conto: irónicos, de escarnio, eufemísticos Despóis de comer ben, a espresión desta satisfacción non pode ser «estóu cheo». Repútase como de mala educación. Debe decirse «estóu farto», «estóu satisfeito»; «vou coma un Pepe» ou «coma un cuco», son vulgares.

Nas partes do corpo faise distinción entre as da xente e as dos animales. «Beizos», «fuciños», «narnes», «croca», «patas», «chambrós» son as partes do corpo dun animal. Usadas pra personas son despectivos e de escarnio (Ten us beizos

${ }^{19}$ Os nomes da inebriación] Na copia. 
coma unha vaca. Alí ven o Támaro dando ós chambrós). «Labios», «nariz», «rabadilla», «pernas», «pes», «maus», «dedos», «dedas» (as dos pes), «hombreiros», e outras son partes do corpo humano, así como «estámago», «pulmós», etc. «Boca», «cabeza», «testa», «dentes», «moas», «unllas», etc. son comús. «Colo» nos animás son as vértebras cervicales e nas personas o regazo, o seo (ten o neno no colo). É un caso de dislocación semántica dos que deixamos visto.

No tocante ás funciós hai tamén diferencia. As dos animás non está mal visto que se usen coas súas espresiós directas. Das mulleres dise que «caeron en estado», «que están co feixe á boca», «que caeron na cama», "que están torcendo as liñas», e neste caso, pídese a Dios pra elas «unha horiña pequena».

Cos vellos gárdanse moitas consideraciós de tipo eufemístico. "Velliño» e «meu vello» son palabras que se usan máis ben cos nenos e personas de mediana edá. Nunca cos vellos. En espresiós como éstas: «¿que fai o vello, qué di o vello, morreu o vello?», a palabra "vello» ten un matiz de escarnio que non permite pronunciala diante un vello de verdá. «Vello» chega á sinificar o demo. Inda que non esteña un vello diante, unha persona ben falada dirá que «fulano de tal xa vai sobre os seus días», "que conta moitos cucos» e aínda pode chegar á decir «que poucos anos lle quedan», «que está cun pe na sepultura». Pero non dirá nunca que é vello. Ó reves: as espresiós anteriores atenúanse decindo que «a vellez non o mata», que «de vello ninguén morre», que «ben pode cos anos» e outras.

Os saludos e despedidas teñen tamén as súas formas elementales de boa crianza. Á unha persona maior non se debe saludar cun «bos días», «boas tardes» a secas. "Boas tardes nos día Dios» é o comedido. "Adiós», díselles ós mortos. As despedidas, ó salir de misa, son; «Dios nos día gozo do ben». E a resposta é: «amén, á todos». As despedidas normales son: «pasalo ben», «non morrerse», «que non haxa novedá». E as respostas: «querendoo Dios», «querendo o ben».

Os nomes de personas tamén se poden volver de mal gusto pola moda. Conocín un vello que me dixo que quería mellor que lle chamasen ladrón que que lle chamasen Xan. Xan, decía el, chámaselles ós burros. As «Sabelas», «Fucas» e «Farrucas» que eu conocín de neno acabáronse. Hoxe chámase «Urcisinas», (de Ursicinia), «Ermundas» (de Edmunda), «Luminadas» (de Iluminada).

Os nomes dos oficios poden ser tamén de mal gusto: «albardeiros», «zarrulleiros», «capadores» prefiren que se lles chame «maestros», e así se fai cando se fala con eles ou á súa cara. 
Ás cargas sociales de calquer tipo renovouselles o nome en varias ocasiós por eufemismo. Pero a xente síguelles chamando "pagas» ou «trabucos», que é un trabucamento cheo de intención, en vez de "tributo».

Hoxe en día o eufemismo anda de capa caída. A misma lengua literaria busca a espresión directa, como cansada da falsedá de moitas convenciós, e comprácese en falar crú e sin rodeos, contrastando coa lengoa embostera das propagandas de toda clas, que nos chegan en afiches, diarios, radios, discursos e outros medios de espresión. As reuniós de xente ben falada son cada vez menos e falsas. Gánanlles a partida as grandes moreas de xente que arrastran os deportes e nas que o eufemismo está desterrado. O escarnio, que non imos á estudiar nas súas raíces, impera na espresión libre, quizaves por unha razón social tamén. As formas cristalizadas, de calquer tipo que señan, son antivitales.

\section{Interxeuciós e onomatopeias}

\section{Interxeuciós}

Entre as creaciós afectivas están as interxeuciós, que, en moitos e dos casos, non son máis que formas embrionarias de lenguaxe, sinos naturales que temos en común cos animás.

Nas formas máis sinxelas son berros, asociados naturalmente á unha afección de alegría, ademiración, dolor, sorpresa, etc. según o tono dos mismos. Así, «jai!», «jei!», «joi!», «jui!», «jfo!», «iba!», «ibo!».

Co tempo dáselles outros oficios: sirven pra chamar á xente, pra tornar e deter o gado e pra guialo, e aínda pra espresar reacciós ideolóxicas de asentimento, negación, duda, desconfianza, ou distintas afecciós, máis ou menos complicadas, que non son as orixinarias. Nestes casos solen ir acompañadas de outras palabras.

Tras destas interxeuciós veñen as formadas por palabras sinificativas, usadas como interxeuciós. Son debidas, orixinariamente, á estados violentos que impiden a articulación dunha frase enteira, polo que damos solta nunha sola palabra á toda a nosa carga afectiva. Interxeuciós deste tipo son "iXesús!», «Dios!», «¡Sanatońo!», «iCorio!», «iCarenio!», «iCarapio!», «iDemoro!». Moitas son deformaciós de tipo eufemístico.

As interxeuciós que sirven pra chamar ós animás son repeticiós das primeiras sílabas do seu nome. («Pipipí», «curícurí», «cochecoche», «cabúxcabúx»). As que 
sirven pra guialos son frases mutiladas. De "casacasa», que se usa pra afalar ás ovellas, galiñas e outros animás, e de "toma-toma», con que tamén se chama, máis o adverbio «aquí», penso que se ten formado a interxeución «Casquitó!», que se usa pra tornar os animás que están facendo mal. De forma semellante esplicaría "toaquí», "teiquí», "teique».

Outras veces trátase da mutilación dun elemento simple: «itó!». En «¡oité!» súmase ó elemento mutilado a interxeución propia: «ioi!»

A maioría das interxeuciós son compostas. Unhas veces por repeticiós: «jfofó!», «ibabá!», «ibobó!», «ibupá!», «ipupá!», «ipuparralla!».

«iAi!», e «joi!» entran en interxeuciós de dous componentes sin soldar, como en «jai, fó!», «¡oi xente!», «¡oi oyéu!», que sirve pra chamar á un desconocido.

Moitas interxeuciós son verdadeiras fórmulas piadosas trocadas de sinificado. "Avemaría», "avemaria de gracia» denotan estrañeza e ademiración.

(Anque damos sinificación concreta a algunhas interxeuciós, debe terse en conta que a trocan doado, según a entonación. «Avemaría», poño por caso, sirve ós probes pra chamar ás portas).

\section{A onomatopeia}

As onomatopeias, por fin, son tamén creaciós de tipo afectivo. Como se dixo ó falar do redoblamento, que ven á ser, en gran parte, a técnica de que se vale, a onomatopeia consiste, de seu, en tratar de reproducir ruídos e sonidos regulares e repetidos preferentemente. É procedimento de lenguas primitivas, pero que responde á un sentimento de placer que se encontra na imitación. Polo placer de ver reproducidas as cousas, que todos sentimos, o «Voo do moscón» ten sempre ésito e, por eso mismo, os nenos se non cansan nunca de que lles repitamos o mesmo xogo de palabras, que eles despóis non se han de cansar de repetir tampouco.

Os grados da onomatopeia son tres: o de simple ruído imitativo («bisbis», «chouchóu», «tis-tás»), o de interxeución («icataplún!», «izas!») e o de sustantivo.

$\mathrm{Xa}$ dixemos como son moitos os páxaros que levan nomes onomatopeicos (cuco, rula, chasco, paspallás ). Fora deste grupo, quedan outros moitos, herdados ou orixinarios, como «estalido», «estoupo», «estarabouzo», «miar» (os gatos), «mear» (as ovellas), «muar» (as vacas), «zuar», «rumbar» e moitos máis. 


\section{A LENGUA, ESPELLO DA HISTORIA}

\section{1. [A VIDA DAS PALABRAS]}

A historia das palabras é o espello da das cousas, da dos costumes e ideas, e non se pode entender sin ter en conta aquela. A historia dos préstamos que recibimos de Castilla non se podería esplicar sin a historia da incorporación de Galicia ó estado español. Moito menos se esplicaría, sin ter en conta a historia, que se separase hasta tal punto do portugués que fonéticamente estivera hoxe máis cerca do castellano.

A aparición da misma lengua supón as fondas crises políticas e sociales que houbo no país desde o siglo IV ó X. Non abondaba a esistencia das lenguas prerromanas, portadoras de mínimos vitales, pra transformar tan profundamente o latín. É por eso que non se comprende o orixe de moitas palabras sin conocer as circunstancias históricas do momento en que chegaron a nós, e os tecnicismos de grupos e organizaciós.

Mirada por enriba, a palabra "paisano» non trocóu de sinificado desde o seu orixe. Arrancaría da palabra pagus, que sinificaba aldea labrega, e todo consistiría en buscar a forma fonética que a esplicase. Pero nosoutros sabemos que non é así. O latín que chegóu ás aldeas de Galicia portaba no seu vocabulario o viño novo do Cristianismo, no que paganus, pagano, sinificaba o que hoxe sinifica. Sabido esto, a palabra "paisano» diríanos, si o non soupésemos, que as nosas aldeas non se convertiron de seguida ó Cristianismo e que, nun comenzo, tivo unha sinificación relixiosa. Ó pasar o Cristianismo ás aldeas, foi cando volvéu á sinificar «home do campo» e o seu valor relixioso expresouse por medio dunha regresión, dunha volta á mai, como diríamos en gallego.

«Cativo» é unha palabra moi xeneralizada pra sinificar baixo, fraque, feo, e, en algunhas comarcas, neno de pouca edá. Todas estas sinificaciós dinnos moito dos prisioneiros que chegaron á Galicia cando as loitas coa mourisma, pero sírvenos mellor a sinificación que tiña captivus pra penetrar as que hoxe ten «cativo». 
O carácter monacal da organización eclesiástica gallega vese no nome especializado que aquí se lles deu ós lugares de culto. Entre o siglo IV e o VIII especializóuse ecclesia, pra sinificar reunión de comunidá e basilica pra sinificar costrución destinada ó culto sobre unha tumba célebre, santuario, etc.

Dentro desta especificación, os monxes non conocían máis que ecclesia, que era as duas cousas, centro de reunión da comunidá e lugar destinado ó culto. A monxa Etheria e San Fructuoso non falan máis que de ecclesia. Algús documentos reales e episcopales falan de «basélica». Pero o nome que pasóu á lengua foi «iglesia» ou «eirexa». Ó lado dela, conoce ermida, tamén de orixe monacal.

«Catedral», «basílica», «capilla» (capela nos documentos), «santuario», son todas de importación.

O estado de desbaraxuste en que Galicia debéu quedar, despóis das cabalgadas suevas e das que despóis viu pasar, vese recordando os nomes de habitación humana.

Civitas desbancóu pronto á urbs en latín vulgar. En Galicia é seguro que non houbese ningunha urbs. Despóis de civitas, das que, ó parecer, houbo moitas, viña castrum, unha clas de fortín pra caso de guerra, un campamento fixo, reducido. Aparte estaba a villa, que era unha finca de campo con máis ou menos edificaciós ó seu redor. Onde as circustancias o permitían vía medrar ó seu lado as casas dos colonos, sin por eso trocar de nome, pero si de sinificado. A villa clásica, zarrada sobre sí, pequena en estensión de terras, debe ser a clausa, que deu a nosa «chousa».

Fora destes centros había aínda os vicos, que parece que desinaban os caseríos que se iban formando ó redor das vilas en algús casos. Eran de tipo rural.

De todos estes nomes non quedóu en gallego máis que «vila», non pasando os outros de topónimos xa desde moi vello. Todos se fundiron como se fundiron as cousas que sinificaban. Na revolta dos Suevos, Galicia quedaba convertida nun infinito número de aldeas, á aldea por vila. Había de ver levantarse no sitio das ciudades os «burgos». Pero éstes non habían de deixar tampouco máis que o nome de burgueses e algún que outro locativo á partir da Edá Media. Foi ó redor de «vila» que se desenvolvéu a desinación dos lugares habitados. Cando éstas se agrandaron por circustancias favorables, pasaron á ocupar o lugar das vellas ciudades. Eran as vilas. As menos prósperas entón, foron «casales», «aldeas», e os grupos estraños, que o comercio e outras circustancias amontoaban ó redor das 
vilas, foron os «arrabaldos». A organización eclesiástica deu nome ás «parroquias», que agrupaban varias aldeas e casales. ¡Cánto nome perdido e cánto novo!.

Algo parecido ocurríu coa «casa». As casas patricias chamábanse domus. Casa era o nome que trouxeran os colonizadores pra desinar as casas labregas. Aparte estaba a capanna, casa de pastores, onde non cabía máis que unha persona según a etimoloxía de S. Isidoro. Tampouco aquí quedou máis que a «casa» e a «cabana». As vilas dos manates derrumbáronse, pasando o seu nome a sinificar outra cousa, como acabamos de ver. As miserables chouzas dos nativos, das que nin siquera conocemos o nome, debeulles pasar igual, inda que por outra razón. Boas ou malas non quedaron máis que casas, pra a xente, e cabanas de pastor, que se irían agrandando pra recoller os ganados de inverno.

Coa nova organización medieval deron en aparecer os «pazos», residencias de obispos, herdados dos manates da curia de outro tempo, e os «castelos», residencia dos señores. Mais, cando chegóu á ser meirande o esplendor de us e outros (siglos XV e XIII), desapareceron os seus nomes como cousa viva.

Os castelos foron derrocados polos Hermandinos e polos Reises Católicos. Algús volvéronse á erguer. Pero daquela xa se chamaban castillos.

Os pazos dos manates, ó chegar o XVI, tamén se fixeron palacios, á tenor da lengua dos seus señores, representantes sempre do poder oficial. Quedoulles o nome de pazos ás edificaciós dos señores rurales. Cando estes os deixaron no XIII final, sobre todo no XIX, cando a quebra dos señoríos, us pasaron tamén á palacios e outros quedáronse en fincas.

Os hospitales da Edá Media siguen co vello nome, restrinxido no sinificado. O que eles perderon herdárono as palabras hotel e parador. Os mesós franceses foron cousa do XIX, e hoxe están reducidos á «fondas», «paradores», «casas de comidas». Este siglo é o das grandes novedades en todo. Os hespitales pasan a ser «dispensarios», «ambulatorios», «sanatorios», por un eufemismo oficial.

A palabra «hotel», sin perder o seu sinificado dezanoveno, pasa á sinificar o que viña sinificando «villa», de orixe italiano e "chalet», de orixe suízo. Pero no medio de tanta novedá, tornan as sombras do pasado. Coa prosperidá dos señores gallegos volve o seu nome ós pazos, que, asombrados polas casas dos burgueses do XIX, se habían convertido modestamente en fincas. O pazo volve á ser un tipo de casa especial e a palabra, convertida xa fai tempo nun nome de lugar, renace á nova vida. Non lla aseguramos longa, por eso. 
A lei que rixe as lenguas é o cambio, e hoxe sobre todo. Renovarse ou morrer é un refrán que anda na boca de todos. As fábricas e industrias multiplican os seus produtos e cada un ten que levar un nome que chame a atinción da xente, amiga de novedades. Este produto hai que renovalo ó cabo de catro días, pra atallar a competencia e, con el, o nome. Nesta cadea xira todo o mundo, o zapateiro, o arquiteuto e o profesor.

A organización política, económica e hasta a relixiosa, anda á crear novas formas e á criar novas relaciós. Como o afán de novedá e o espíritu de orixinalidá veñen aguilloados polo de propaganda, evítase repetir nomes de outros ou que xa esteñan gastados. O número de neoloxismos que aparece cada ano é grande e aumenta cos que chegan de todo o mundo por tódolos medios de comunicación con que contamos. O aspecto que hoxe ofrece calquera lengua é a de un remuíno de palabras, un fervelloar lésico como nunca se ten visto e que está moi lonxe de ter chegado ó seu máximum, porque o momento histórico que vivimos é ese, e a lengua ten que refrexalo.

\section{AS PALABRAS MORREN}

Acabamos de decir que estamos vivindo nun remuiño de palabras novas que nos chegan de todas partes, e que este remuíño aumentará á medida que Galicia vaia entrando máis adentro na roda de vida que envolve o mundo.

Esto, claro está, non ocurre en balde. Nestes remuínos desmoróanse moitas vécelas lenguas. E si non chegan á desmoroarse — cousa que se dá moi de raro en raro e nun conxunto de circustancias que en poucos momentos se dan- sufren, con todo, grandes baixas no seu vocabulario e aínda desgastes na súa estrutura.

Cada lengua non ten máis que o vocabulario preciso pra a espresión cabal da vida da xente que a fala, na medida en que esteña desenvolta ésta. Á un nivel cultural, artístico, económico máis alto, á unha vida interior máis rica, corresponde tamén unha lengua máis numerosa.

Un cambio no nivel de vida supón un abandono de moitos usos, prácticas e útiles, definitivamente superados. Polo tanto, ós neoloxismos que a nova vida comporta, corresponderán tamén moitas baixas no vocabulario tradicional. 
As causas da morte dunha palabra non é, con todo, algo tan sinxelo como do que vimos decindo se deduce. Podemos dividilas en dous grupos: dun lado as de orde social, que son as que aludimos hai pouco, e de outro, as de orde lingüístico. Unha palabra pode morrer porque desaparece a cousa que sinifica — «monteira», «xibón», «dengue»—, porque pasóu de moda (mesón), causas de orixe social, ou porque a vence outra palabra mellor feita e máis espresiva, como «gornir» e «levar», da lengua medieval, vencidas por «gornecer» e «levantar».

É moi clara a influencia social no lenguaxe, na vida e morte das palabras, e, por outro lado, falamos bastante do seu poder ó analiza-la función de espello que a lengua ten con relación á historia e vida da sociedá.

Réstanos sólo decir catro palabras das causas lingüísticas que provocan a morte dunha palabra.

Unha palabra, coma un individo humano, non empeza e acaba en sí. O normal é que seña o derradeiro eslabón dunha cadea que chega hasta as orixes dunha lengua e dunha xente. Homes e palabras vivimos sobre unha pila de mortos.

A diferencia está en que unha palabra que vive é sempre a causante da morte da que a precede, porque a lengua, como a vida, é unha loita á morte. As palabras que vencen, vencen por algo. O normal é que teñan certas ventaxas fonéticas sobre as vencidas. Que señan máis longas e que se fixen mellor polo tanto, como pasa entre "gornir» e "gornecer».

Pode ser tamén porque esteñan apoiadas nunha familia máis numerosa. As pensiós chamáronse hasta fai moi pouco tempo "pre». "Quedoulle un pre de quince pesos». Hóxe chámanse "pagas». Esta palabra ten a ventaxa sobre «pre» de evocar espontáneamente a imaxe do beneficio, pero sobre todo a de apoiarse nunha familia de palabras meirande: "pagar», "pago», "pagado», "pagamento», «pagaduría». Frente á ela, «pre» ven á ser unha palabra semánticamente froxa e islada no medio do vocabulario gallego.

Outra palabra ben viva no gallego falado foi a de "cólico miserere», da que ninguén se esquencéu aínda. Hoxe, por eso, chámaselle "pendicites», que leva camiño de facer esquencer cólico miserere. A razón está en que "pendicites» é un tecnicismo, unha espresión limpa e xusta. Sin necesidá de complemento, espresa, nin máis nin menos, os cólicos máis de temer, apoiada por outro lado en razós de afectividá social, por ser de moda, novedosa e sabia. 


\section{A homonimia fatal}

Este é o epíteto que Brunot e Bruneau lle deron á homonimia polo feito de ser unha das primeiras causas fonéticas da morte das palabras. Xa falamos deste fenómeno como renovador da lengua. Todo o que alí se dixo vale pra aquí, hasta certo punto.

Sin traballos previos, mapas lingüísticos, vocabularios locales, etc., non podemos ver toda a importancia deste fenómeno, polo que se refire á morte das palabras. Polo carácter preferentemente falado do gallego, que non conta cos pequenos sinos diferenciales da lengua escrita pra marcar a división de sinificado entre dous homónimos, atrevémonos á decir que é moi grande.

Cando dúas palabras chegan a ser prácticamente iguales poden ocurrir dúas cousas: que teñan sinificación semellante ou moi separada. Neste caso non hai peligro pra ningunha das dúas. Nestas frases: «ten un pote na testa», «pon o pote ó lume»; «levóu un bon golpe», «levoulle o golpe os pitos»; «pegueille un croque» e «marchóu ós croques á ribeira», a homonimia é inofensiva.

Pero si os homónimos se acercan semánticamente hai peligro de que un desapareza, como xa se dixo. De «lea», loita, sale «learse» e de «lea», corda, «lear», atar. Non hai dificultá porque os sinificados aparecen bastante lonxe un do outro. Pero o sinificado de «deslear», «separar a dóus que se pegan»e «deslear», «desatar un fardo que ven leado», tende a xuntarse nunha misma imaxe muscular e a lengua acusa este fenómeno, visto que creóu a forma «desenlear» pra o segundo caso.

Sin este recurso, a necesidá de evitar a anfiboloxía deixaría nada máis que a un dos dous. O vencido podía desaparecer ou quedar cunha sinificación restrinxida. «Engrea» sinificaba un tipo de corda coa que se ataban lixeiramente os pelexos nunha carga de viño. No tempo dos arrieiros prosperóu moito, e o verbo derivado, «engrer» ou «engrir», usouse pra sinificar o feito de atar lixeiramente un carro de herba ou de toxos, pra evitar que co bambeo se torcera, e, logo, poder apretalo debidamente, tirando xa con forza do adibal.

Cos arrieiros desapareceron as «engreas», pero o verbo «engrir» quedóu coa súa sinificación limitada.

De florere e plorare deberan nacer «chorer» e «chorar», pero fundíronse fonéticamente na misma forma. «Chorar», botar flores e «chorar», botar bágoas, eran 
os dous parónimos. Non estaban moi cerca os sinificados, pero, de calquera maneira, o primeiro reaccionóu e volveu á fonética primitiva dando «florear». Non desaparecéu, por eso, de todo. Hoxe ninguén di «chorar» por florear, pero este verbo, quizaves por un reforzo metafórico, mantense na sinificación restrinxida de "chorar o liño», e mantense tamén o seu derivado «chorimas» pra indicar as flores dos toxos e das xestas.

É por esto que, da homonimia, máis ben resultan ganancias que perdas.

\section{A compricación morfolóxica}

Outra causa da morte das palabras ven da compricación das súas formas. O Latín Vulgar desfíxose de gran parte dos verbos anómalos, e o gallego refixo moitos dos que así resultaron, por razós fonéticas. «Soar» volveuse á mais e deu «sonar».

Non é tanto un castellanismo, como pensamos, senón unha regresión polo camiño do castellano. «Soar» é unha palabra doada de decir. Pero ¿quén non sinte medo á meterse polo medio de formas tan compricadas como «eu soo», "tú soas»; «eu soe», «tú soes»; «soaría», «soaréi», pensando sobre todo no verbo «soer», onde nos atoparíamos con «eu soo» outra vez, «tú soes», «el soe»; «tú soas»; «soería», «soeréi»?

A pouco que pensémolas veces que damos volta diante certas formas de verbos da lengua común, que realmente están caducadas, e as que facemos uso de perífrasis, antes de usar unha forma que nonos ven ó oido, darémonos conta de cantas están mortas e de por qué solecen tan ben os neoloxismos.

O enemigo número un do vocabulario é, con moito, o cambio da sociedá, dos usos, costumes, aveños, útiles de cociña, etc.

«Culler», xa hoxe, non é máis que o nome das culleres de buxo. "Coitelo» é o de matar os cochos e o de pelar as patacas, que siguen facendo os ferreiros do país. O servicio de mesa do patrón, comprado no bazar, componse de «cuchares», «tenedores» e «cuchilos». 
Si puidéramos facer un balance, pra rematar este capítulo das perdas e ganancias, veríamos que hai grandes desequilibrios, según os tempos. Nos de prosperidá económica, social e intelectual, son máis as ganancias. Nos de regresión social, o imperio das masas e o seu espiritu simplista, sin tradición, empobrécea. No nos atrevemos á marcar os períodos que se poderían facer na historia do gallego neste sentido. Os feitos aparecen moi compricados pola dualidá permanente de aldea-vila que hai en Galicia e que non podemos ver hasta que punto colaboran ou non na obra social que é a lengua.

Sobre a ola de neoloxismos que hoxe invade o gallego xa falamos noutros sitios. É un feito estraordinario polo volume, pero normal en sí.

\section{OS NOMES PROPIOS}

No estudio do vocabulario que hasta aquí viñemos facendo, deixamos á un lado as palabras que non teñen valor por sí (artículos, pronomes, preposiciós e conxunciós) e aquelas outras que teñen un valor que non trascende dun mismo ser e que chamamos nomes propios.

Das primeiras non trataremos, por non poder facerse o seu estudio fora da sintasis; pero dos nomes propios parécenos ben decir catro cousas.

Non se pode facer unha raia xusta entre os nomes propios e os comús. $\mathrm{Na}$ historia do vocabulario vese como os propios se poden facer comús e os comús propios.

Os nomes de persona de hoxe foron, nun comezo, nomes de cousas; convertíronse en alcumes, máis tarde, e, logo, no que hoxe son. Dos apellidos xa non se diga, e dos nomes de lugar.

Nomes de persona e nomes de lugar están sometidos, coma os comús, a toda clas de alteraciós, pero a súa historia ten características propias, que os separan totalmente deles, aínda sin contar coas semánticas.

Os nomes de lugar teñen un arraigamento como non se atopa en ningunha outra palabra. Os de persona, polo contrario, varían dunha xeneración á outra, coma os peinados e as formas dos traxes das mulleres.

Os nomes de lugar mais antigos son os de ríos de algunha importancia. Desde o Eo hasta o Miño e o Sil, pasando polo Xallas, o Tambre, o Ulla, o Umia e 
outros, os nosos ríos levan nomes que é escusado buscar no fondo orixinario da lengua. Si o Miño leva un nome latino é que pasóu de España á Roma moito antes da nosa colonización, inda que moito despóis que o Miño fose Miño.

Hai outros topónimos en Galicia que se supoñen anteriores á colonización e á chegada dos celtas, como son algús dos rematados en -ASCO, -ASCA, -OSCO, -USCO, e -ANCO, -ANCA. Da misma maneira, algús dos que comenzan polo radical BORN-, BORM- e BORB-. A tenor desto serán topónimos precéltigos algús dos que en Galicia teñen estas características, como «Viascón», «Oscos», «Ledusco», «Travanca», «Ancos», «Nemancos», «Cusanca», «Borbén», «Borneiro» e outros así. Digo algús deles e non todos porque as homofonías casuales non son raras nestes casos.

Do mismo orixe que os sufixos mencionados, estudiados por Menéndez Pidal, é -ALLO, polo que puideran espricarse topónimos moi vellos como "Calo», "Abalo», «Bealo», "Argalo» e, de non tratarse de redoblamentos primitivos, que os faría aínda mais antigos, puideran relacionarse con temas do mismo orixe que os propostos por Menéndez Pidal, «Corcoesto», «Corcubión» e "Córcores», que descansarían sobre o tema lírico CORC-.

Os citados por Menéndez Pidal, que son os das primeiras series dependen de xentes veciñas de lígures e ilirios, moi mesturadas con éstes, ás que lles dá o nome de «Ambrós». Con eles liga os topónimos de «Ambroa» e «Ambroz» e os moi correntes de «Lamas». Estes últimos, con todo, penso que puideran ser latinos, visto que a palabra lama, como outras moitas prelatinas, entróu moi axiña nesta lengua. Ennio chegóu a usala, o que revela a súa vulgarización no latín falado. O que se multiplique en Galicia é un feito máis xeográfico que lingüístico, dada a súa sinificación.

Neste punto eu penso que hai que ter sempre en conta que o latín tivo desde cedo encontros con moitas xentes e que tomóu delas moitas palabras, bastantes máis das que pasaron ós libros. Estas fóronse perdendo ó longo dos camiños do Imperio por ser bocaladas de soldados ou latixos familiares, pero algunhas puideran quedar dando nome ós lugares de campamento e ós releves que lles chamaran a atinción ós soldados e provocaran calquera destes nomes.

Os topónimos nacidos desta maneira non serán menos celtas ou preceltas, pero o seu valor histórico, que é o que se busca nestes casos, é moi distinto. 
A nosa toponimia prerromana, en particular, non conta con estudios serios recentes, aparte os que lle dedicóu Menéndez Pidal e amplióu Moralejo Laso. Según estes estudios, aparte os en -BRIGA, son de orixe celta os en -OBRE, -EBRE, -ABRE, que dan unha serie bastante numerosa e moi sinificativa. Faltan series polo estilo nos temas, que serían máis interesantes pra conocer algo da vida dos celtas gallegos. O mismo profesor, D. Abelardo Moralejo, presenta algús destes temas, pero islados, sin que ningún se repita, o que non é moi de fiar en principio.

As creaciós toponímicas da época da romanización son as máis numerosas e variadas. Dannos características topográficas e de orde social (Outeiro, Taboada, Cospeito, Vilas e Castros en tódalas variantes); laborías e sistemas de cultivo (Rozas, Vedra, Vedro, Busto, Chantada); donos de predios, cando a terra comenzóu á ter valor (Vilaquinte, Moeche, Ventín, Cea e quizaves Pruzos, dun Pelusius que figura nas inscripciós gallegas); nomes de santos (Santalla, Sanxenxo); comarcas de asentamentos das distintas xentes que aquí conviviron (Galegos, Céltigos, Godos, Suevos); inmigraciós das épocas das invasiós árabes (Toldaos, Cumbraos); nomes de posesores bárbaros (Allariz, Guntín).

Sobre a maior parte destes temas ten estudios acabados o profesor J.M. Piel da Universidá de Coimbra, así como numerosos estudios etimolóxicos.

A fisonomía toponímica de Galicia desfigurouse pouco desde o siglo X. Pra velo basta ler un documento desta época. Reducidos á forma fonética actual, a maior parte responden ós que temos hoxe, con moi poucas novedades.

A desinación primeira dun nome de lugar pode ser debida á unha decisión da autoridá. Un documento relativo ó bispo Odoario, que se dá por falso, pero que nos sirve pra este caso, descríbenos como foi dando nomes ás terras dos arredores de Lugo, tomando como temas os nomes das xentes que viñan con el de Africa, en calquer sentido que se tome esta espresión. Poden ser falsos os feitos pero o método esistía no tempo do falsificador do documento.

O Ferrol cambióu de nome nos nosos tempos, e Vilasobroso é un topónimo do 1925.

O xeneral é que estas denominaciós señan espontáneas e que se asenten sobre particularidades da xeografía física ou humana, sobre nomes de persona e moi poucas veces sobre nomes de feitos históricos. 
Os cambios débense algunha vez á decretos autoritarios, que casi nunca levan, como se ve polos nomes de prazas e rúas, nas que se chegan á cambiar os nomes sin ninguén os use. $\mathrm{O}$ normal é que cambien por cambiar algunha circunstancia xeográfica, física ou humana.

Cerca de onde escribo había un lugar que lle chamaban «a Capela». A capela había tempo que desaparecera, e seguíase chamando igual. Un día pasóu por alí unha carretera. Outro día veu a empalmar con ela, na «Capela», un camiño veciñal. Desde entón chámase «o Empalme».

No monte Orneiro, que cantóu Noriega pensando que se chamaba «Arneiro» e correxiu máis tarde nun soneto moi delicado, había unha cabana de ovellas que se chamaba «a Casa das ovellas». Era punto de referencia. Hoxe chámase «a Emisora», porque cerca da cabana se levantóu unha das torres dun observatorio meteorolóxico moi importante.

Estes son os únicos cambios que caben. Os nomes dos ríos, dos montes, dos vales, das terras, das vilas e aldeas van con eles hasta o cabo.

Nos nomes de persona todo é ó revés. O sistema onomástico latino xa nos chegóu bastante alterado e non tardóu en fundirse baixo a combinación de barbarismo e cristianismo, que é de onde arranca o gallego.

Prisciliano, Egeria e os Avitos xa nos chegan cun nome nada máis. Nas inscriciós verifícase o mismo. Pra unha que traia prenomen, nomen e cognomen, hai dez que non.

A partir da chegada dos suevos e visigodos impóñense os nomes deste orixe, frente ós do calendario eclesiástico, debido á que había interés en mantelos, pra aparentar a descendencia da nobilísima gens gothorum, herdeira de tódolos privilexios. Este interés vivo en conservar o nome dos ascendentes fixo que os nobles, sobre todo, comezasen á poñer cabo do seu nome o dos pais e abós, que se repartían os fillos por un compricado sistema, pero de modo que cada un non levaba máis que dous nomes: o de pía, propio, e un familiar, que podía ser o do pai ou o do abó. Diego Xelmírez, poño por caso, Arias Pérez.

$\mathrm{O}$ crecemento da nobleza, á partir do siglo $\mathrm{X}$, foi grande e fixo falla un terceiro nome, que se tomóu normalmente do título dos condados, ducados, marquesados e señoríos, pra a nobleza, e das vilas en que vivían, oficios e alcumes, pra as xentes libres. Fernando Pérez de Traba, Fernando García Esgarabuña, Xoan Airas de Santiago. 
As xentes do común seguiron co nome de pía e co alcume que lles daba unha boa alma. Nada tiñan que herdar os probes: Xoan Zorro, Xoan Bolseiro, Pero d'Armeá.

Á medida que a organización social foi máis precisa e apareceron listas contributivas por todas partes, foi quedando menos xente sin nomes claros por onde ser reconocido. Os que non tiñan patronímicos de sangre, leváronos de caridá. Os servos das iglesias e cotos monacales chamábase da Iglesia.

Os da arquiña, tiveron diversos apellidos: Iglesia, Somoza, Rei, Espósito.

Repasando un libro de mortos do XVII, atopéi moitos nomes de pía sin patronímico. María do Grelo, muller de Antonio do Val, María da Cabana, tal cual aínda se conocen as xentes das aldeas, polos lugares onde viven.

Debido á unha intervención directa do estado, despóis que se acabaron os señoríos, hoxe ten todo o mundo tres nomes, coma no tempo de Roma, que indican o propio do individuo e ó da ascendencia paterna e materna.

Os nomes de familia e os de lugar, oficio ou alcume non cabe escollelos, pero os de pía, sí. Abundaron sempre os dos santos, desde a nosa evanxelización, pero a moda imperóu sempre. Primeiro pra manter os das vellas familias romanas: Prisciliano, Avito. Logo, os da nobleza suevo-visigoda: Branderico, Taramundo.

A Edá Media gallega conocéu nomes de diversa procedencia, sobre todo en servos, pero os normales son visigóticos ou de santos vellos: Alfonso, Fernando, Rodrigo, entre os primeiros; Xoan, Pedro, Payo e Martín, entre os segundos.

A letanía dos santos, que se canta nas rogativas de S. Marcos, e noutros días, foi a fonte principal dos nomes de pía, hasta chegar os nosos tempos, e, desde o Concilio de Trento, por outro lado. Dese período datan as Liberatas, Aguedas, Anastasias, Andreas. O XVIII, siglo de señoríos rurales, trouxo da corte a moda dos nomes compostos, sobre todo pra mulleres. María-Francisca, Xuana-Tomasa, María-Serafina, Rosa-Francisca, Xuana-Xacinta, todos eles imitación dos da nobleza.

O XIX, coas súas guerras carlistas, rebaixóu o tono señoril do XVIII aldeano. $\mathrm{Xa}$ non se atopan tantos nomes compostos. En xeneral vólvese ós vellos, hasta que, coa difusión de almanaques e repertorios, se estendéu a moda de buscar nomes raros, e de fora do país, que non interesan, polo de agora, á lengua máis que calquera nome turco. 


\section{BIBLIOGRAFÍA}

Dado que este traballo é máis que nada un ensayo preliminar, un intento de levantar a armazón principal do que ha de constituír a historia da lengua gallega cando se teñan feitas tódalas investigacións que cada un dos seus tramos require, escúsome de non ter feito as referencias concretas ós datos que se manexan. Todos eles foron tomados da lengua viva e da bibliografía que se cita. Aparte os autores e obras que van ó final, tivemos en conta tódolos estudios que citamos no capítulo dedicado ó Estudio do Gallego e aínda os que se citan islados e non figuran aquí.

Giacomo DEVOTO, Storia della lingua di Roma. Bologna, 1944.

E. BOURCIEZ, Éléments de linguístique Romane. París, 1946.

C.H. GRANDGENT, Latín Vulgar, Trad. de F. de B. Moll. Madrid, 1928.

V. GARCÍA DE DIEGO, Gramática histórica española, Madrid, 1950.

R. MENÉNDEZ PIDAL, Toponimia prerrománica Hispana. Madrid, 1952.

Samuel GILI-GAYA, Fonética general. Madrid, 1950.

Tomás NAVARRO TOMÁS, Pronunciación española. Madrid, 1950.

A. ERNOUT et A. MEILLET, Dictionaire étimologique de la langue latine. París, 1951.

Amado ALONSO, Estudios lingüisticos (Temas españoles). Madrid, 1951.

Manuel C. DÍAZ Y DÍAZ, Antología del latín vulgar. Madrid, 1951. 
Índice orixinario

\section{ÍNDICE}

INTRODUCIÓN

O ESTUDIO DO GALLEGO

\section{O VOCABULARIO}

1. XENERALIDADES

2. ESTENSIÓN E PROFUNDIDÁ DUN VOCABULARIO.

3. FONDO ORIXINARIO DO VOCABULARIO GALLEGO

1. IMPORTACIÓN

\section{RENOVACIÓN DO VOCABULARIO}

2. COMPOSICIÓN

3. DERIVACIÓN

A) PREFIXACIÓN

B) SUFIXACIÓN

I. VERBOS

II. NOMES

III. ADXETIVOS

IV. DERIVACIÓN ANALÓXICA, IMPORTADA E REGRESIVA

\section{VIDA ÍNTIMA DAS PALABRAS}

1. OUTROS CAMBIOS DE FORMA

2. CAMBIOS DE SINIFICADO

3. A LENGUA ESPELLO DA CULTURA E DA SENSIBILIDÁ

4. A LENGUA ESPELLO DA HISTORIA

5. AS PALABRAS MORREN

6. OS NOMES PROPIOS

Bibliografía 